ELEN DE PAULA BUENO

\title{
BRICS E AS REFORMAS DAS INSTITUIÇÕES INTERNACIONAIS
}





\title{
BRICS E AS REFORMAS DAS INSTITUIÇÕES INTERNACIONAIS
}

\begin{abstract}
Tese de Doutorado apresentada à Banca Examinadora do Programa de Pós-Graduação em Direito, da Faculdade de Direito da Universidade de São Paulo, como exigência parcial para obtenção do título de Doutora em Direito, na área de concentração de Direito Internacional, sob a orientação do Professor Titular Dr. Paulo Borba Casella.
\end{abstract}

UNIVERSIDADE DE SÃO PAULO

FACULDADE DE DIREITO

São Paulo - SP 
Bueno, Elen de Paula

BRICS e as Reformas das Instituições Internacionais / Elen de Paula Bueno; orientador Paulo Borba Casella São Paulo, 2018. 336

Tese (Doutorado - Programa de Pós-Graduação em Direito Internacional) - Faculdade de Direito, Universidade de São Paulo, 2018.

1. BRICS. 2. Direito internacional. 3. Relações Internacionais. 4. Multilateralismo. 5. Reforma das Instituições Internacionais. I. Casella, Paulo Borba, orient. II. Título. 


\section{FOLHA DE APROVAÇÃO}

Nome: BUENO, Elen de Paula.

Título: BRICS e as reformas das instituições internacionais.

Tese de Doutorado apresentada à Faculdade de Direito da Universidade de São Paulo como exigência parcial para obtenção do título de Doutor em Direito.

Aprovado em:

Banca Examinadora:

Prof.Dr. Instituição:

Julgamento: Assinatura:

Prof.Dr. Instituição:

Julgamento: Assinatura:

Prof.Dr. Instituição:

Julgamento: Assinatura:

Prof.Dr. Instituição:

Julgamento: Assinatura:

Prof.Dr. Instituição:

Julgamento: Assinatura: 



\section{AGRADECIMENTOS}

Inicialmente, agradeço ao meu orientador, professor Paulo Borba Casella, pela confiança em meu projeto de pesquisa, pela orientação e por todo o apoio conferido na consecução da presente tese.

Agradeço ao Victor por todo o apoio e companheirismo nas mais importantes fases da minha vida.

Agradeço ao meu pai, quem desde a minha infância ensinou-me a ver o mundo por meio de mapas, livros e leituras.

Agradeço à minha mãe, pelo imenso apoio a todos os meus sonhos e projetos.

Agradeço aos colegas do GEBRICS/USP por todas as ricas discussões teóricas realizadas nos dois anos de existência desse importante grupo de pesquisa e por todo o trabalho conjunto concretizado na I Jornada dos BRICS na USP.

Agradeço a todos os meus professores, da UNESP e da USP, que ricamente contribuíram para a minha formação acadêmica ao longo desses anos.

Agradeço ao Paulo Nogueira Batista Jr., pela entrevista concedida à pesquisa.

Aproveito o ensejo para agradecer aos professores que lecionaram na Fudan University, pela experiência e valioso aprendizado proporcionados durante o período de estudos na China. 



\section{RESUMO}

BUENO, Elen de Paula Bueno. BRICS e as Reformas das Instituições Internacionais. 2018. $336 \mathrm{p}$.

Tese (Doutorado em Direito Internacional). Faculdade de Direito, Universidade de São Paulo, São Paulo, 2018.

No início do século XXI, o agrupamento formado por Brasil, Rússia, Índia, China e África do Sul levantou uma das principais bandeiras em prol do fortalecimento do multilateralismo e das reformas das instituições internacionais. Os BRICS, ao longo das cúpulas realizadas desde 2009, discutiram e apreciaram os principais temas internacionais do presente século, sobretudo em matéria de reforma das instituições internacionais, meio ambiente, segurança internacional, sistema econômico global, desenvolvimento e modelos de cooperação. A presente tese de doutorado visa analisar o papel dos estados emergentes, especificamente dos BRICS, no fortalecimento e na reforma das instituições internacionais no século XXI. A primeira parte da pesquisa aborda as hodiernas perspectivas e discussões teóricas do direito internacional a respeito dos principais desafios apontados pela literatura, sobretudo no que diz respeito ao fortalecimento do multilateralismo. A segunda parte analisa o papel dos BRICS e seus impactos nas relações internacionais, bem como a atuação conjunta do grupo no sentido de influenciar decisões e alcançar as reformas das instituições internacionais.

Palavras-chave: BRICS. Direito Internacional. Relações Internacionais. Multilateralismo. Reforma das Instituições Internacionais. 


\begin{abstract}
BUENO, Elen de Paula Bueno. BRICS and the Reforms of the International Institutions. 2018. $336 \mathrm{p}$.

Thesis (Doctorate in International Law). Law School, University of São Paulo, São Paulo, 2018.
\end{abstract}

In the early twenty-first century, the group formed by Brazil, Russia, India, China and South Africa have raised one of the main banners in support of the strengthening of multilateralism and the reform of international institutions. The BRICS, over the past summits held since 2009 , discussed and appreciated the major international issues of this century, especially on the reform of international institutions, environment, international security, global economic system, development and cooperation models. This thesis aims to analyze the role of emerging states, specifically the BRICS, in strengthening and reforming international institutions in the twenty-first century. The first part of the research deals with the current perspectives and theoretical discussions of international law regarding the main challenges pointed out in the literature, especially with regard to the strengthening of multilateralism. The second part analyzes the role of the BRICS and its impact on international relations, as well as the Group's joint efforts to influence decisions and achieve the reforms of international institutions.

Keywords: BRICS. International Law. International Relations. Multilateralism. Reform of International Institutions. 


\section{RÉSUMÉ}

BUENO, Elen de Paula Bueno. BRICS et les Réformes des Institutions Internationales 2018. 336 p.

Thèse (Doctorat en droit international). Faculté de Droit, Université de São Paulo, São Paulo, 2018.

Au début du XXIe siècle, l'ensemble formé par le Brésil, la Russie, l'Inde, la Chine et l'Afrique du Sud, a levé l'un des principales drapeaux a fin de renforcer le multilatéralisme et des réformes des institutions internationales. Les BRICS, lors des sommets tenus depuis 2009, ont discuté et apprécié les grandes questions internationales de ce siècle, en particulier la réforme des institutions internationales, l'environnement, la sécurité internationale, le système économique mondial, le développement et les modèles de coopération. Cette thèse de doctorat vise à analyser le rôle des Etats émergents, en particulier les BRICS, dans le renforcement et la réforme des institutions internationales dans le XXIe siècle. La première partie de la recherche porte sur les perspectives actuelles et les discussions théoriques du droit international en ce qui concerne les principaux défis identifiés dans la littérature, notamment en ce qui concerne le renforcement du multilatéralisme. La deuxième partie examine le rôle des BRICS et son impact sur les relations internationales et les efforts conjoints du Groupe pour influencer les décisions et à réaliser la réforme des institutions internationales.

Mots-clés: BRICS. Droit International. Relations internationales. Multilatéralisme. Réforme des Institutions Internationales. 


\section{RESUMEN}

BUENO, Elen de Paula Bueno. BRICS y las Reformas de las Instituciones Internacionales. 2018. 336 p.

Tesis (Doctorado en Derecho Internacional). Faculdad de Derecho, Universidad de São Paulo, São Paulo, 2018.

A comienzos del siglo XXI, la agrupación formada por Brasil, Rusia, India, China y Sudáfrica planteó una de las principales banderas en favor del fortalecimiento del multilateralismo y de las reformas de las instituciones internacionales. Los BRICS, a lo largo de las cumbres realizadas desde 2009, discutieron y apreciaron los principales temas internacionales del presente siglo, sobre todo en materia de reforma de las instituciones internacionales, medio ambiente, seguridad internacional, sistema económico global, desarrollo y modelos de cooperación. La presente tesis de doctorado pretende analizar el papel de los estados emergentes, específicamente de los BRICS, en el fortalecimiento y la reforma de las instituciones internacionales en el siglo XXI. La primera parte de la investigación aborda las actuales perspectivas y discusiones teóricas del derecho internacional sobre los principales desafíos señalados por la literatura, sobre todo en lo que se refiere al fortalecimiento del multilateralismo. La segunda parte analiza el papel de los BRICS y sus impactos en las relaciones internacionales, así como la actuación conjunta del grupo para influir en las decisiones y alcanzar las reformas de las instituciones internacionales.

Palabras clave: BRICS. Derecho Internacional. Relaciones Internacionales. Multilateralismo. Reforma de las Instituciones Internacionales. 


\section{ABREVIATURAS}

ACUNS - Conselho Acadêmico do Sistema das Nações Unidas/ Academic Council on the United Nations System

ACR - Arranjo Contingente de Reservas

AGNU - Assembleia Geral das Nações Unidas

AIIB - Banco Asiático de Investimentos em Infraestrutura/ Asian Infrastructure Investment Bank

ASEAN - Associação de Nações do Sudeste Asiático/ Association of Southeast Asian Nations

BAD - Banco Asiático de Desenvolvimento

BID - Banco Interamericano de Desenvolvimento

BIMSTEC - Iniciativa da Baía de Bengala para a Cooperação Econômica e Técnica Multissetorial/ Bay of Bengal Initiative for Multi-Sectoral Technical and Economic Cooperation

BIRD - Banco Internacional para Reconstrução e Desenvolvimento

BED - Banco Euroasiático de desenvolvimento

BEI - Banco Europeu de Investimentos

BERD - Banco Europeu para a Reconstrução e o Desenvolvimento

BNDES - Banco Nacional de Desenvolvimento Econômico e Social

BRICS-ARP - Plataforma de Investigação Agrícola dos BRICS

$\mathrm{CDH}$ - Conselho de Direitos Humanos das Nações Unidas

CAF - Corporação Andina de Fomento/ Banco de Desenvolvimento da América Latina

CFI - Corporação Financeira Internacional

COP - Conferência das Partes

CSNU - Conselho de Segurança das Nações Unidas

DPI -Direito de Propriedade Intelectual

ECOSOC - Conselho Econômico e Social das Nações Unidas / Economic and Social Council

EMDCs - Mercados Emergentes e Países em Desenvolvimento/ Emerging Market and Developing Countries

FAO - Organização das Nações Unidas para a Alimentação e a Agricultura/ Food and Agriculture Organization of the United Nations 
FMI - Fundo Monetário Internacional

FONPLATA - Fundo Financeiro para o Desenvolvimento da Bacia do Prata

GATT - Acordo Geral de Tarifas e Comércio/ General Agreement on Tariffs and Trade

GCTEC - Grupo de Contato sobre Temas Econômicos e Comerciais dos BRICS

IIB - Banco Internacional de Investimentos/ International Investment Bank

OMC - Organização Mundial do Comércio

MoU -Memorando de Entendimento/ Memorandum of Understanding

MRE - Ministério das Relações Exteriores

NAFTA - Tratado Norte-Americano de Livre Comércio/North American Free Trade Agreement

NBD - Novo Banco de Desenvolvimento

NEPAD - Nova Parceria para o Desenvolvimento de África

NOEI - Nova Ordem Econômica Internacional

OCDE - Organização para a Cooperação e Desenvolvimento Econômico

OCI - Organização para a Cooperação Islâmica

ODM - Objetivos de Desenvolvimento do Milênio das Nações Unidas

OIT - Organização Internacional do Trabalho

OMS - Organização Mundial da Saúde

ONU - Organização das Nações Unidas

OPEP - Organização dos Países Exportadores de Petróleo

OTAN - Organização do Tratado do Atlântico Norte

PIB - Produto Interno Bruto

PPP - Parceria Público-Privada

PNUD - Programa das Nações Unidas para o Desenvolvimento

PNUMA - Programa das Nações Unidas para o Meio Ambiente

RCA - República Centro Africana

RDC - República Democrática do Congo

RPC - República Popular da China

SAARC - Associação Sul-Asiática para a Cooperação Regional/ South Asian Association for Regional Cooperation

TIC - Tecnologias de Informação e Comunicação 
UA - União Africana

UE - União Europeia

UfC - Unidos pelo Consenso

UNCAC - Convenção das Nações Unidas contra a Corrupção/ United Nations Convention against Corruption

UNCITRAL - Comissão das Nações Unidas para o Direito Comercial Internacional/ United Nations Commission on International Trade Law

UNCOPUOS - Comitê das Nações Unidas para o Uso Pacífico do Espaço Exterior / United Nations Committee on the Peaceful Uses of Outer Space

UNCTAD - Conferência das Nações Unidas sobre Comércio e Desenvolvimento/ United Nations Conference on Trade and Development

UNODA - Escritório das Nações Unidas para Assuntos de Desarmamento/ United Nations Office for Disarmament Affairs

UNFCCC - Convenção-Quadro das Nações Unidas sobre a Mudança do Clima/ United Nations Framework Convention on Climate Change 



\section{LISTA DE TABELAS}

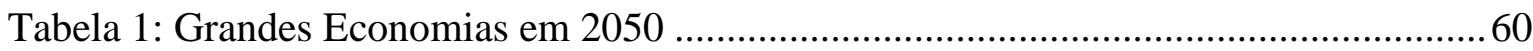

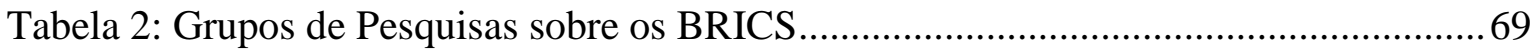

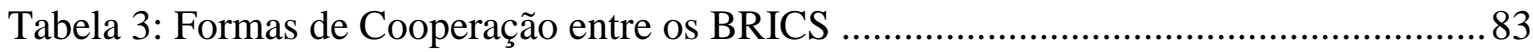

Tabela 4: IV Cúpula dos BRICS: Segurança e Meio Ambiente.......................................... 87

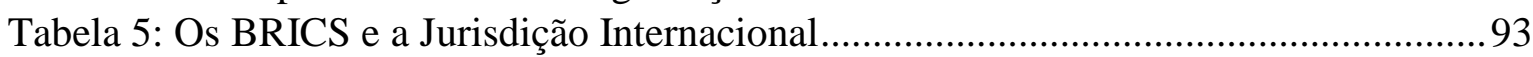

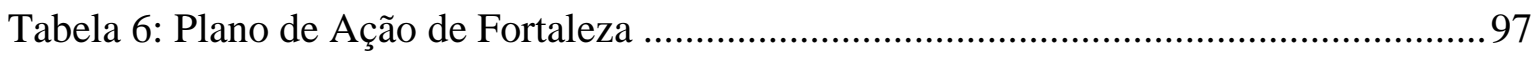

Tabela 7: Declaração de Ufá - Segurança Internacional ..................................................... 100

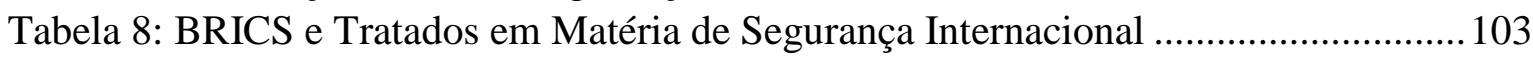

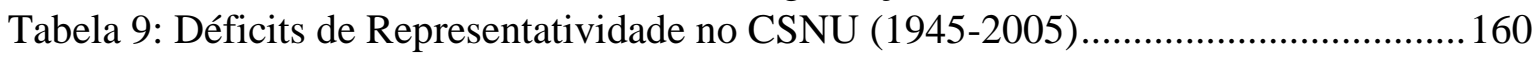

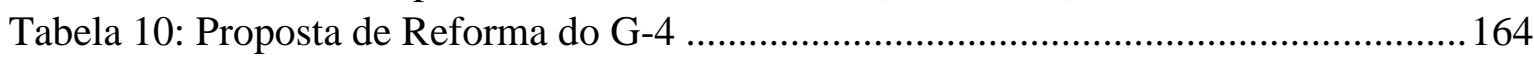

Tabela 11: Sistema de Cotas FMI/Reformas 2008 e 2010 .............................................211

Tabela 12: Cotas-partes e de Votação antes e após a Implantação das Reformas Acordadas

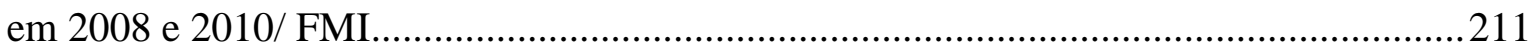

Tabela 13: Distribuição de Ações e Direito de Voto NBD ................................................228

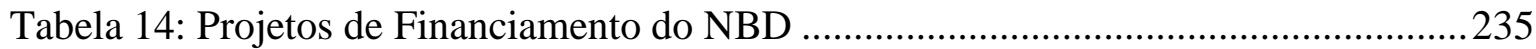





\section{SUMÁRIO}

INTRODUÇÃO

CAPÍTULO I: O DIREITO INTERNACIONAL NO SÉCULO XXI: ENTRE A

AMBIVALÊNCIA E O MULTILATERALISMO

1.1 Direito e Relações Internacionais: aspectos para a compreensão da governança global 42

CAPÍTULO II: DIMENSÕES INTERNA E EXTERNA DOS BRICS: CÚPULAS, DOCUMENTOS E MOVIMENTOS DE COOPERAÇÃO 55

2.1. O surgimento do acrônimo 55

2.2. Conceitos e contribuições teóricas à análise dos BRICS 59

2.3. Cúpulas, Documentos e Movimentos de Cooperação e Reforma. 72

2.3.1. I Cúpula e a Declaração Conjunta de 2009: o início de um diálogo 74

2.3.2. II Cúpula e a Declaração Conjunta de 2010: a consolidação de uma agenda comum 77

2.3.3 III Cúpula dos BRICS e a Declaração de Sanya de 2010: o ingresso da África do Sul... 79

2.3.4 IV Cúpula dos BRICS e a Declaração de Nova Délhi de 2012: reformas e preocupações ambientais

2.3.5.V Cúpula dos BRICS e a Declaração e Plano de Ação de eThekwini, Durban, março de 2013: A infraestrutura como chave para o desenvolvimento

2.3.6 VI Cúpula e a Declaração e Plano de Ação de Fortaleza, de julho de 2014: a assinatura do Acordo Constitutivo do Novo Banco de Desenvolvimento

2.3.7 VII Cúpula dos BRICS e a Declaração de Ufá, 2015: agenda comum em matéria de segurança internacional.

2.3.8 VIII Cúpula dos BRICS e a Declaração de Goa, 2016: primeiros caminhos para a cooperação comercial, econômica e de investimentos intra-BRICS.

2.3.9 IX Cúpula dos BRICS e a Declaração de Xiamen, 2017: ampliação da cooperação intraBRICS

CAPÍTULO III: OS BRICS E AS REFORMAS DAS INSTITUIÇÕES INTERNACIONAIS.... 133

3.1. O ajuste das organizações internacionais ao contexto pós-moderno 133

3.2 BRICS e a Reforma do Conselho de Segurança das Nações Unidas.... 142

3.2.1. O Conselho de Segurança e o sistema de segurança coletiva das Nações Unidas . 145

3.2.2. Breve histórico sobre os projetos de reforma do CSNU 
3.2.3. A atuação do G-4 e de outros grupos nos projetos de reforma do CSNU

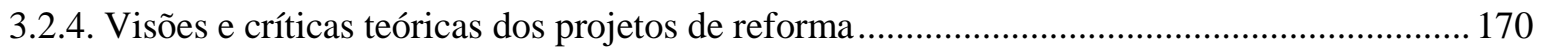

3.2.5 Os BRICS e o Conselho de Segurança das Nações Unidas..................................................... 184

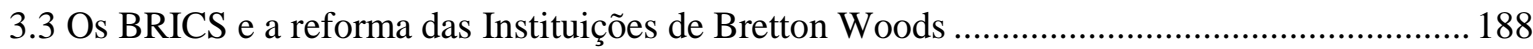

3.3.1 O contexto histórico de criação das instituições de Bretton Woods....................................... 192

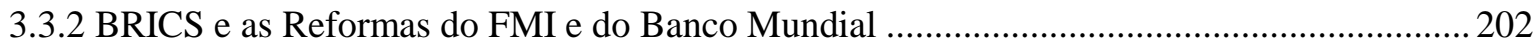

3.4 O Novo Banco de Desenvolvimento (NBD) e o Acordo para o Estabelecimento do Arranjo

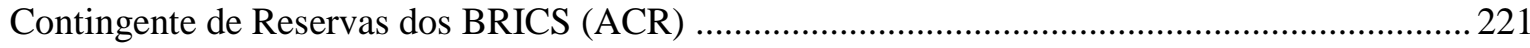

3.4.1. Objetivo, Funções e Estrutura do Novo Banco de Desenvolvimento (NBD) ...................... 227

3.4.2. Desenvolvimento e Sustentabilidade: os primeiros projetos do NBD .................................... 233

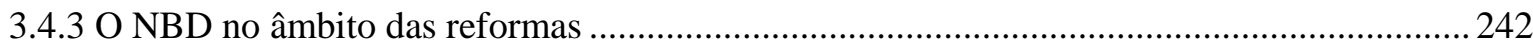

3.5 Relação entre os BRICS e as reformas das instituições internacionais ..................................... 248

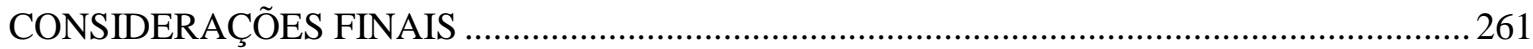

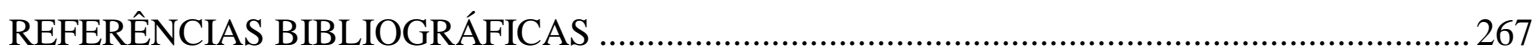

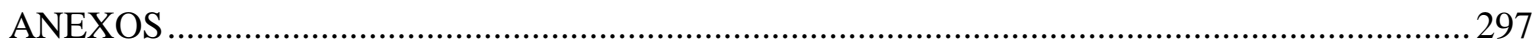

Anexo 1: Entrevista - Questões formuladas ao Vice-Presidente do Novo Banco de

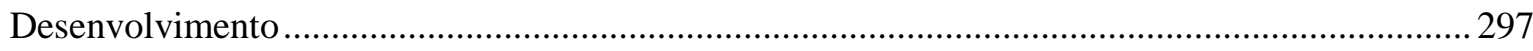

Anexo 2: Acordo Constitutivo Sobre o Novo Banco de Desenvolvimento .......................................302

Anexo 3: Tratado para o Estabelecimento do Arranjo Contingente de Reservas dos BRICS......... 324 


\section{INTRODUÇÃO}

A presente tese examina o papel dos estados emergentes, especificamente dos BRICS, no fortalecimento e na reforma das instituições internacionais ${ }^{1}$ no século XXI. A primeira parte da pesquisa aborda as hodiernas perspectivas e discussões teóricas do direito internacional a respeito dos principais desafios apontados pela literatura, sobretudo no que diz respeito ao fortalecimento do multilateralismo. A segunda parte analisa o papel dos BRICS e seus impactos nas relações internacionais, bem como a atuação conjunta do grupo no sentido de influenciar decisões e alcançar as reformas das instituições internacionais. A hipótese é de que os BRICS, a despeito das divergências, limitações e desafios, podem exercer um papel importante no fortalecimento do multilateralismo e nas reformas do sistema de governança das instituições internacionais, contribuindo para o reforço da legitimidade das organizações multilaterais e para uma perspectiva transcivilizacional do direito internacional.

A institucionalização das relações internacionais e o fortalecimento dos mecanismos de cooperação passarão inelutavelmente pelo crivo do direito internacional, que deverá se adaptar ao contexto pós-moderno ${ }^{2}$ e atualizar suas estruturas à luz do multilateralismo e do contexto multicultural. O direito internacional não é um sistema estático, mas condicionado aos processos de mudanças da sociedade internacional. A legitimidade do exercício jurídico igualmente se modifica - tanto como um fenômeno social empírico como um conceito normativo ${ }^{3}$. Nesse contexto, as organizações internacionais e seus órgãos devem igualmente se adaptar, pela prática e pela flexibilização dos seus instrumentos jurídicos, aos novos contornos e circunstâncias do tempo ${ }^{4}$. O direito internacional pós-moderno acarreta revisão dos modelos institucionais e normativos herdados de outras eras. Esse sistema de direito internacional pós-moderno encontra-se em

\footnotetext{
${ }^{1} \mathrm{Na}$ presente tese de doutorado o termo "instituição internacional” é utilizado no sentido amplo, abrangendo fóruns multilaterais, organizações internacionais e seus respectivos órgãos.

${ }^{2}$ CASELLA, Paulo Borba. Fundamentos do direito internacional pós-moderno. São Paulo: Quartier Latin, 2008.

${ }^{3}$ WEILER, Joseph H. The geology of international law. Governance, democracy and legitimacy. Heidelberg Journal of International Law, n. 64, 2004, pp.547-562.

${ }^{4}$ HERNDL, Hurt. Reflections on the role, functions and procedures of the Security Council of the United Nations. Recueil des Cours. Hague Academy of International Law, v. 206, 1987, p. 358.
} 
construção. O pós-moderno volta-se para o passageiro, para o contemporâneo, para o que se situa além dos paradigmas pretensamente estáveis da modernidade ${ }^{5}$.

A sociedade internacional centralizada no estado e com valores tipicamente ocidentais do século XX transformar-se-á em uma sociedade multipolar e multicivilizacional no presente século ${ }^{6}$. O poder adquirido por estados emergentes poderá afetar substancialmente a estrutura jurídica global e culminar em modelos equitativos de cooperação ${ }^{7}$. Além disso, a herança deixada pelo século XX em numerosas partes do mundo, isto é, uma desigualdade dos estados face ao desenvolvimento ${ }^{8}$, poderá ser revista e compreendida à luz da percepção dos estados emergentes que congregam, interna e externamente, as grandes contradições do sistema econômico global.

Hodiernamente existe uma vasta literatura a respeito dos efeitos das mudanças de poder sobre a política internacional. Entretanto, os internacionalistas do direito raramente examinam como as distribuições e alterações de poder modificam as instituições e o direito internacional. As relações internacionais são formadas por vários fatores históricos, geográficos, econômicos e políticos. Nesse contexto, as mudanças ocorridas no âmbito da sociedade internacional inelutavelmente afetam o direito internacional ${ }^{9}$.

Como compreender o direito internacional diante das realidades emergentes do século XXI? O direito internacional pós-moderno volta-se, justamente, para o que ainda está em formação, e que pode ou não vir a ser consolidado ${ }^{10}$. Nessa esteira, o direito internacional

\footnotetext{
5 "Desconstruído o mundo, e neste, o direito, em relação às pretensões codificadoras, sistematizadoras e totalizantes, herdadas do século xix, e doravante marcadas pela visão duplamente crítica, pois esta tem consciência, quanto à necessidade de revisão e adaptação, para que possa intervir e interferir de modo válido, para a regulação do sistema legal do mundo, e se põe, de modo igualmente crítico, em relação à adequação dos instrumentos legais de regulação, diante das exigências e desafios do futuro" CASELLA, op.cit., 2008, p.67.

6 “A perspectiva que chamo de 'transcivilizacional' pode auxiliar na solução desses problemas práticos, normativos e epistemológicos, expandindo nossas preocupações, questionado nossas premissas evidentes ou axiomáticas e ampliando nossas perspectivas de forma multifacetada. Trata-se de uma perspectiva através da qual podemos ver, reconhecer, interpretar, avaliar e buscar a proposição de soluções para ideias, atividades, assuntos e problemas, os quais transcendem as fronteiras nacionais, através do desenvolvimento de uma estrutura cognitiva e avaliadora baseada no deliberado reconhecimento de uma pluralidade das civilizações existentes há muito tempo na história da humanidade. Trata-se de uma perspectiva que as pessoas já têm adotado inconscientemente quando veem assuntos 'internacionais'. É necessário que esclareçamos essa perspectiva e a reconstruamos como uma ferramenta útil para apreciação de aspectos complexos e das dimensões associadas ao direito internacional no mundo multipolar e multicivilizacional do século XXI". ONUMA, Yasuaki. Direito internacional em perspectiva transcivilizacional. Questionamento da estrutura cognitiva predominante no emergente mundo multipolar e multicivilizacional do século XXI. CASELLA; Paulo Borba; NINOMIYA, Masato (Org.). Belo Horizonte: Arraes, 2017, p. 22.

7 CASELLA, Paulo Borba. BRIC: Brasil, Rússia, Índia e China: uma perspectiva de cooperação internacional. São Paulo: Atlas, 2011, p. 16.

${ }^{8}$ LACHS, Manfred. O Direito internacional no alvorecer do século XXI. Estudos avançados, v.8, n.21, São Paulo May/Aug 1994. Do original: Le droit international à l'aube du XXi siècle, R.G.D.I.P., n. 3, pp. 529-550, 1992.

${ }^{9}$ BEDJAOUI, Mohammed. International law: achievements and prospects. Paris: UNESCO, 1991, p.3.

${ }^{10}$ CASELLA, Paulo Borba, op.cit., 2008, p. 897.
} 
pós-moderno encontra doravante a tarefa direcionada aos estudos dos processos em formação, bem como a necessidade de, no campo acadêmico, desenvolver-se mediante contribuições originais à ciência.

Uma vez considerada a mudança nas constelações de poder no século XXI, a busca por democratização, legitimidade e reformas será uma constante no seio da sociedade internacional. Nesse sentido, a doutrina internacional deverá responder a esta nova realidade e reconstruir sua teoria de acordo com ela (ONUMA, 2017). Como salienta CASELLA (2008), o direito há de ser entendido não como uma mera técnica, mas como parte da construção humana, entre história e cultura, bem como entre política e moral.

A ascensão dos países emergentes está criando novas demandas para a democratização e o reforço das instituições multilaterais. O resultado é uma nova gama de opções estratégicas disponíveis para os países em desenvolvimento e um novo imperativo de reformar e revitalizar organizações multilaterais e regionais ${ }^{11}$. SLAUGHTER e HALE (2010), sob uma perspectiva liberal, ressaltam a importância dos mecanismos inovadores de governança global e para a resolução de crises. Os autores argumentam que as redes informais transgovernamentais podem conferir às potências emergentes ${ }^{12}$ maior voz e influência no cenário mundial. À vista da modificação da realidade internacional nos últimos anos, aponta-se para um aprofundamento da crise de legitimidade na tomada de decisões internacionais pelas tradicionais potências moldadoras da ordem mundial. Consequentemente, o equilíbrio de poder mundial no presente século modificou-se e possibilitou a diversidade de atores e polos que estão fora do tradicional círculo de poder ocidental Estados Unidos - União Europeia - Japão, o que expressa uma descentralização de decisões e possibilita o surgimento da multipolaridade ${ }^{13}$.

O mapa do século XXI provavelmente será muito diferente do século XX em termos de distribuição de poder em escala global. Como já defendido por muitos especialistas, o mundo no século XXI será provavelmente multipolar ao invés de unipolar ou bipolar. Os principais agentes desse

\footnotetext{
11 "The rise of the global South and a shift in global power towards emerging economies-China, in particular - has become more obvious. China and other emerging economies have forged deeper and stronger economic relations with neighbors and across the developing world". WOODS, Ngaire et. al. Transforming global governance for the 21st century. New York: UNDP Human Development Report Office, occasional paper, 2013, p.1.

12 Outro modelo com raízes no institucionalismo liberal diz respeito ao "great-power concert". Neste, a transição da unipolaridade para a multipolaridade seria pacífica e as potências emergentes atuariam como supporters e um novo equilíbrio de poder, que se exprimiria por instituições multilaterais fortes, seria instaurado e garantiria a estabilidade. SCHWELLER, Randall. Emerging powers in an age of disorder. Global Governance, v. 17, n. 3, jul./set., 2011, p. 289.

${ }^{13}$ BIJOS, Leila; GUILHON, Erick P. Brics: uma alternativa de poder? Londrina: Revista do Direito Público, v. 9, n.1, jan./abr. 2014, p.14.
} 
sistema multipolar: Estados Unidos, países da Europa Ocidental, China, Índia e talvez alguns outros como a Rússia, Japão e Brasil, têm perspectivas culturais, religiosas e civilizacionais que diferem significativamente entre si. Parecemos estar em um momento no qual é preciso considerar os problemas a partir de uma perspectiva associada a diversas civilizações, não se limitando à moderna civilização ocidental. O mundo do século XXI não só será multipolar, mas também multicivilizacional (ONUMA, 2017, p. 21).

Há uma percepção generalizada de que o poder está mudando na política global e que as potências emergentes estão assumindo um papel mais proeminente, ativo e importante. Com efeito, o sistema global é cada vez mais caracterizado por uma difusão de preferências, com mais vozes exigindo serem ouvidas, como um resultado da globalização e da democratização. Os desafios do presente século levantam questões em torno da ordem política, do sistema jurídico e da governança econômica global ${ }^{14}$. O mundo mudou consideravelmente e hoje é mais diversificado e mais complexo, a fluidez das informações e dos capitais torna os equilíbrios menos estáveis e as relações institucionais tendem a tornarse voláteis. Apesar das fragilidades existentes, nem todas as relações internacionais são regidas somente pela força. O papel dos princípios e das normas de direito internacional precisa fazer-se acompanhar dos respectivos procedimentos adequados de implementação e controle de execução ${ }^{15}$.

A formação de um grupo que une Brasil, Rússia, Índia, China e África do Sul, por si só, já possui um caráter inovador no direito internacional e nas relações internacionais. Diferentemente do fortalecimento dos regionalismos que caracterizou a segunda metade do século XX, os BRICS surgem como uma reunião daqueles que, por razões econômicas, políticas, demográficas ou militares, uniram pretensões comuns e mecanismos equitativos de cooperação. Enquanto o regionalismo leva em conta fatores como traços culturais, geográficos e históricos, o fenômeno BRICS congrega culturas distintas, dimensões históricas e ordenamentos jurídicos diferentes, bem como uma considerável distância geográfica. A discussão acerca dos motivos pelos quais cinco distintos países optaram por unir agendas e interesses recíprocos encontra nas relações internacionais a sua vastidão, principalmente no que concerne aos interesses econômicos. Sob o prisma do direito internacional, a inovação diz respeito a um encontro que se deu em momentos de paz e que pode contribuir para novos arranjos internacionais no presente século.

${ }^{14}$ HURRELL, Andrew; SENGUPTA, Sandeep. Emerging powers: North-South relations and global climate politics. International Affairs, v. 88, 3, 463, 2012, p. 463.

${ }^{15}$ CASELLA, op.cit., 2011, p. 107. 
O "fator BRICS" não é apenas um embrião de modelos legais e políticos alternativos de cooperação entre vários países; pode ser igualmente compreendido como um laboratório interessante de orientações normativas internacionais alternativas, reforçando a percepção de um processo de transformação inevitável de todos os edifícios conceituais e normativos de direito internacional. Nesse contexto, embora uma realidade multicultural não seja inteiramente nova, pela primeira vez, os chamados países emergentes ${ }^{16}$ têm os meios para influenciar o direito internacional ${ }^{17}$.

Contrariamente às críticas de que o BRICS não traz novas ideias à regulamentação global e promete investir pouco na produção de bens públicos globais, PAPA (2014) argumenta que o BRICS já é um regulador inovador porque introduz a noção de uma transição negociada estrategicamente para além da lei hegemônica, para uma multipolaridade implementada através de uma coalizão de países que representa mais de $40 \%$ da população mundial. A sua ascensão também apresenta debates sobre a soberania como responsabilidade socioeconômica e abre espaço para sua evolução normativa para abordar a produção de desigualdades através da regulação global ${ }^{18}$. No mesmo sentido, BIJOS e GUILHON (2014, p. 45) entendem que a governança global se assume como inovação do incipiente processo democrático internacional no qual os estados da comunidade mundial posicionam-se sobre os temas que lhes afetam diretamente. Com efeito, a inclusão dos BRICS no rol dos principais atores internacionais para a governança do mundo é importante porquanto propicia o surgimento de novos debates e a convergência entre posições diferentes. De acordo com CASELLA (2011), a perspectiva BRICS não diz respeito somente aos países participantes, mas, igualmente, no sentido de colegiado que, ao operar de modo ordenado e eficiente, poderá redesenhar a cooperação no mundo pósmoderno.

\footnotetext{
16 "Face à l'impact des pays émergents sur le droit international, il semble exister un double besoin d'adaptation. D'une part, bien évidemment, tous les États de la planète qu'ils soient développés ou en développement devront trouver sur le plan juridique les voies et moyens permettant de prendre en considération la place et le rôle des pays émergents dans le système international. D'autre part, la seconde exigence concerne la doctrine juridique qui sera très certainement de plus en plus appelée à analyser le développement du droit international à l'aune de l'influence des pays émergents". PRADEL, Nicolas. Pays émergents et droit international: l'enjeu de l'adaptation. L'Observateur des Nations Unies, Association française pour les Nations Unies, 2013, v. 33, 2012, p.2.

${ }^{17}$ GIANNATTASIO, Arthur R. Capella; CARDOSO, Luís F. de Paiva Baracho. Structural challenges in a multipolar and multicultural global legal era: BRICS' global legal politics beyond cultural and economic partnerships. São Paulo Law School of Fundação Getulio Vargas - DIREITO GV, Research Paper Series Legal Studies Paper n. 87, 2014, p. 10.

${ }^{18}$ PAPA, Mihaela. BRICS as a global legal actor: from regulatory innovation to BRICS law? Rivista di diritto pubblico italiano, comparato, europeo, 2014, p. 44
} 
Ademais, os BRICS podem contribuir para uma paulatina ampliação de uma perspectiva multicultural em transição. A pluralidade cultural e o multiculturalismo, em relação ao direito internacional, evocam um sentimento de preocupação com a paz: a sociedade multicultural implica a existência de uma diversidade essencial à condição humana e que pressupõe a busca de soluções comuns no contexto de compromisso e respeito ao outro. A pluralidade de concepção culmina no corpo de normas comuns, cada vez mais integradas, a serviço da paz e de melhores condições de vida da pessoa humana na sociedade universal. Assim, o multiculturalismo nos revela sua dupla face, como risco e como oportunidade, para reconhecimento efetivo da humanidade ${ }^{19}$. A perspectiva jurídica dos BRICS poderá fomentar bases para a oportuna e necessária integração de uma agenda pautada na cooperação e no respeito ao direito internacional. Com o movimento das potências emergentes na vanguarda das relações internacionais, novos mecanismos de cooperação serão necessários no sistema internacional ${ }^{20}$.

Como sinaliza CARVALHO (2006, p. 195), o desafio para aqueles que trabalham com o direito internacional será o de compreender o sistema jurídico desde outras possibilidades de sentido, a partir de outras realidades culturais. Se, de um lado, isto exige do jurista, do internacionalista e do diplomata competências e habilidades muito amplas e complexas, de outro, "convida-nos a construir um mundo mais aberto à experiência da alteridade, oferecendo ao direito internacional a oportunidade de ser a expressão legítima da vontade dos povos" 21 .

Como estudar os impactos dos estados emergentes no direito internacional sem levar em conta a política mundial? A presente tese não pretende seguir os remotos debates de separação entre direito e política das escolas europeias ou os recentes diálogos de aproximação da tradição estadunidense. Para a compreensão da sociedade internacional no século XXI, a tese sustenta que a intersecção entre as relações internacionais e o direito

\footnotetext{
${ }^{19}$ DUPUY, René-Jean. Mondialisation et dédoublement du monde. Études internationales (Tunis), n. 63, 1997, p. 66.

20 "Yang Jiemian, the President of the Shanghai Institutes for International Studies, argues that the BRICS countries need to stablish a new partnership, which enables a diverse, broad-based, cross regional and elastics cooperation among the five countries. The cooperation should not be limited to the bilateral trade, finance and energy areas but also needs to include global issues such as climate change, energy, security and international development. He believes the BRICS cooperation, which has been conducted in a gradual, practical, open and transparent way, will serve as a paradigm for the new partnership in the international relations". YING, Huang. BRICS: a new cooperation model in horizon. In: Laying the BRICS of a New Global Order: From Yekaterinburg 2009 to eThekwini 2013. Editors Francis A. Kornegay and Narnia Bohler-Muller. Pretória: African Institute of South Africa, 2013, p.53.

${ }^{21}$ CARVALHO, Evandro Menezes de. Diplomacia e multilinguismo no direito internacional. Revista Brasileira de Política Internacional, n.49, v. 2, 2006, pp. 178-195.
} 
internacional pode contribuir para elucidar os movimentos de mudanças e seus respectivos impactos. Ao final, a presente tese pretende responder às seguintes perguntas: das contribuições teóricas à realidade pós-moderna, como compreender o direito internacional à luz do multilateralismo e da perspectiva transcivilizacional? Qual o papel dos BRICS e seus impactos no direito internacional do século XXI, especificamente em matéria de reforma das instituições, reforço do multilateralismo e modelos equitativos de cooperação?

De modo a responder a esses questionamentos, a tese foi esquematizada em três capítulos. O primeiro capítulo tem por objetivo levantar as hodiernas perspectivas e discussões teóricas acerca do conteúdo ambivalente do direito internacional público em meio à busca de um multilateralismo. A pesquisa parte da premissa segundo a qual o direito internacional terá papel fundamental no século XXI, sobretudo no sentido de garantir a paz e ordenar as relações internacionais, mas que deverá se adaptar, na prática e na teoria, às transformações e à realidade internacional pós-moderna. À luz de uma perspectiva transcivilizacional, busca-se compreender como os estados emergentes podem contribuir ao fortalecimento das instituições internacionais e ao reforço do multilateralismo. O estudo do impacto dos BRICS nas relações internacionais inevitavelmente exige uma análise interdisciplinar, com aportes jurídicos, econômicos, políticos e sociais. Malgrado as diferenças conceituais entre direito e relações internacionais, a tese sustenta que o diálogo entre ambos se torna pertinente ao estudo do objeto e pode contribuir para a compreensão da relação entre os BRICS e as reformas das instituições internacionais. Outrossim, compreende-se que ambas as áreas do conhecimento deverão se adaptar ao contexto pósmoderno e atualizar suas estruturas à luz do multilateralismo e do contexto multicultural, superando tradições dos séculos passados.

O segundo capítulo é dedicado ao estudo das dimensões interna e externa dos BRICS: cúpulas, documentos e movimentos de coordenação e cooperação. A pesquisa literária utilizou aportes da economia e das relações internacionais de modo a compreender as construções conceituais sobre o fenômeno BRICS. Com base em análise majoritariamente documental, procurou-se o histórico de formação, as cúpulas, documentos e movimentos de cooperação do grupo, de modo a compreender seus objetivos e contexto de desenvolvimento.

O terceiro capítulo analisa a relação dos BRICS com os projetos reformadores do sistema de governança das instituições internacionais, especificamente do Conselho de Segurança das Nações Unidas, do Banco Mundial e do Fundo Monetário Internacional. Da busca por reformas das instituições de Bretton Woods, surgiram o Novo Banco de Desenvolvimento (NBD) e o Acordo para o Estabelecimento do Arranjo Contingente de 
Reservas dos BRICS (ACR), que foram abordados detalhadamente ao longo da pesquisa de modo a compreender a relação da trajetória de um simples acrônimo ao advento de uma organização internacional. Embora os BRICS tenham avançado mais em matéria de reforma do sistema de governança das organizações econômicas internacionais, foi conferida igual ênfase ao Conselho de Segurança das Nações Unidas, ao se partir do pressuposto segundo o qual a estabilidade das relações internacionais necessariamente envolve as esferas econômica e política. Para compreender o ajuste das organizações internacionais ao contexto pós-moderno, a pesquisa levou em conta, no âmbito do sistema de segurança coletiva, o histórico sobre os projetos de reforma do Conselho de Segurança das Nações Unidas, as propostas recentes e visões críticas a respeito das limitações dos projetos reformadores. No campo econômico, a pesquisa traçou o contexto histórico de criação das duas principais organizações de Bretton Woods e os recentes projetos de reforma do sistema de governança. Por fim, realizou-se um estudo sobre o Novo Banco de Desenvolvimento (NBD) e o Acordo para o Estabelecimento do Arranjo Contingente de Reservas dos BRICS (ACR), de modo a compreender seus objetivos, funções e estrutura no contexto de reformas.

A metodologia de pesquisa envolveu leitura e identificação de todas as Declarações dos BRICS, bem como dos Tratados e Memorandos assinados. Foram revisados artigos acadêmicos das áreas do direito, das relações internacionais e da economia. A pesquisa também acessou documentos relacionados extraídos dos ministérios dos membros do BRICS e de organizações internacionais. Os resultados foram sistematizados e apresentados na forma de textos, gráficos e tabelas que cruzam os dados e informações.

O estudo dos BRICS revelou que esses países podem exercer um papel decisório no fortalecimento do multilateralismo e nas reformas das instituições internacionais, bem como na prática de modelos equitativos de cooperação. Os países emergentes podem contribuir para a correção de assimetrias passadas, equilibrar o unilateralismo estadunidense e reforçar o multilateralismo e as instituições internacionais. Essas contribuições inelutavelmente deverão passar pelo crivo do direito internacional de modo a obstar que, como nos séculos passados, as mudanças de poder resultem em conflitos, guerras e graves violações de direitos humanos. Nesse contexto, os BRICS podem contribuir de modo a redesenhar o mapa do mundo e das relações internacionais nas próximas décadas. Outrossim, "o direito internacional tem papel crucial a desempenhar no contexto pós-moderno, em função da revisão dos modelos vigentes no mundo, nos planos institucional e normativo" (CASELLA, 2011, p. 3). 


\section{CONSIDERAÇÕES FINAIS}

Embora o advento das Nações Unidas e de outras organizações internacionais tenha representado um dos maiores avanços na história das relações internacionais, as mudanças do presente século impulsionam atualizações ao cenário pós-moderno, em consonância com o multilateralismo e com a perspectiva transcivilizacional. Nesse contexto, posições unilaterais em detrimento do multilateralismo e desequilíbrios manifestamente flagrantes no âmbito da governança não encontrarão mais espaço na atual conjuntura internacional. O direito internacional, entre a ambivalência e o multilateralismo, exercerá papel fundamental no ordenamento das relações internacionais no século XXI. Uma vez condicionado aos processos de mudanças da sociedade internacional, aos contornos temporais e culturais, o direito internacional pós-moderno deverá ajustar-se às realidades contemporâneas, submetendo-se a um novo equilíbrio entre legitimidade e representatividade.

A ascensão dos países emergentes passou a criar novas demandas para a democratização e o reforço das instituições multilaterais no presente século. Nesse contexto, os BRICS firmaram compromissos com o avanço das reformas das instituições financeiras internacionais, de forma a refletir as transformações da economia mundial e de modo a conferir maior protagonismo às economias emergentes e em desenvolvimento. O estudo dos BRICS, como um conjunto, possibilitou a verificação de vertentes muitas vezes ignoradas quando esses países são estudados separadamente. À luz dos aportes interdisciplinares, foi possível aferir, no campo da dimensão externa, que os BRICS, conjuntamente: i) reivindicam a multipolaridade em detrimento do unilateralismo; ii) são os países que, desde o início do século, insistentemente levantaram a bandeira em prol de reformas das instituições internacionais, obtendo alguns resultados efetivos, como observado ao longo da pesquisa; iii) democratizam a sociedade internacional à luz da perspectiva multicultural; iv) oscilam entre o desenvolvimento e o subdesenvolvimento em termos socioeconômicos, o que os tornam mais representativos para atuações em fóruns multilaterais e, finalmente, v) os BRICS, ao longo das cúpulas realizadas desde 2009, discutiram e apreciaram os principais temas internacionais do século XXI, sobretudo em matéria de meio ambiente, segurança internacional, sistema econômico global, desenvolvimento e modelos equitativos de cooperação. A análise dos documentos demonstrou que tanto no campo da dimensão interna, como da dimensão externa, o agrupamento dos países atingiu enorme complexidade, 
afastando-se completamente do conceito original formulado pelo mercado financeiro. Além de expandir os acordos intra-BRICS, baseados em modelos equitativos de cooperação, o grupo atingiu importante coordenação multilateral - que possibilitou a articulação dos cinco países às margens das principais reuniões das instituições internacionais, culminando na conquista, ainda que limitada, da revisão de cotas no sistema decisório do FMI e do Banco Mundial, bem como no advento do Novo Banco de Desenvolvimento, primeira organização internacional criada pelo grupo.

O Novo Banco de Desenvolvimento representou a resposta dos BRICS às deficiências amplamente reconhecidas do sistema financeiro global existente. Um desejo comum de reformar a governança econômica global foi a questão que uniu os BRICS e deu legitimidade no rescaldo da crise financeira global. Durante anos, os BRICS exigiram uma revisão das instituições de Bretton Woods, nas quais as potências ocidentais permanecem sobrerrepresentadas às custas das economias emergentes (LATINO, 2017). Fruto da denominada cooperação Sul-Sul, o NBD foi delineado de modo a financiar projetos sustentáveis de infraestrutura nos países do BRICS e em outras economias emergentes e países em desenvolvimento, com vistas a suplementar os esforços correntes de instituições financeiras multilaterais e regionais de promoção do crescimento e do desenvolvimento internacionais. O comprovado déficit de infraestrutura em muitos países em desenvolvimento, considerado um dos motivos que dificulta as perspectivas de crescimento, envolve um cenário dentro do qual cerca de 1,4 bilhão de pessoas ainda não têm acesso à eletricidade, 900 milhões não têm acesso à água potável e 2,6 bilhões não têm acesso ao saneamento básico (BHATTACHARYA; ROMANI; STERN, 2012), realidade de uma "herança deixada pelo século XX em numerosas partes do mundo, isto é, uma desigualdade dos estados face ao desenvolvimento" (LACHS, 1994). Diante desse fato, o NBD surgiu como o primeiro banco de desenvolvimento não regional pós-Bretton Woods, voltado ao financiamento do desenvolvimento, de modo a atenuar ou superar as situações de desigualdade e de subdesenvolvimento, incorporando a sustentabilidade como principal critério norteador de suas atividades. As temáticas de desenvolvimento e meio ambiente constituíram, ao lado da busca pelas reformas das instituições internacionais, as principais preocupações desses países desde as primeiras declarações conjuntas. A pesquisa demonstrou que, em matéria de meio ambiente, é na esfera do BASIC em que os países, com exceção da Rússia, se articulam e apresentam propostas concretas, sobretudo relacionadas às mudanças climáticas. Quanto ao desenvolvimento, restou demonstrado que os BRICS dedicam atenção ao direito ao desenvolvimento econômico e social, relacionando-o à 
necessidade de garantir as metas estabelecidas pela agenda dos Objetivos de Desenvolvimento do Milênio e ao conceito de desenvolvimento sustentável, inserido como um importante vetor na mudança do paradigma do desenvolvimento econômico.

Diferentemente da área econômico-financeira, na qual os BRICS mais avançaram em matéria de reformas e criação de instituições, a busca por uma reforma no CSNU, embora enaltecido em todas as Cúpulas, logrou poucos resultados concretos. Os reiterados apoios chinês e russo à pretensão do Brasil, da Índia e da África do Sul ao status de membros permanentes do CSNU demonstraram que inexiste pretensão de alterar radicalmente o sistema de segurança coletiva sob o atual modelo onusiano. Apesar da concordância mútua de incorporar novos membros permanentes, os BRICS não chegaram, até o momento, a apresentar um projeto próprio e coordenado sobre a matéria. Apesar disso, os estudos sobre os projetos de reformas do CSNU revelaram a premência de um acordo que possibilite a democratização do mais importante órgão das Nações Unidas. Há um consenso segundo o qual a legitimidade do Conselho encontra-se enfraquecida em razão da morosidade dos projetos de reforma que, como salienta FASSBENDER (2004), inevitavelmente levará a impactos diretos e negativos no sistema como um todo, bem como no próprio direito internacional.

O estudo dos BRICS revelou que esses países podem exercer um papel decisório no fortalecimento do multilateralismo e nas reformas das instituições internacionais, bem como na prática de modelos equitativos de cooperação. Os países emergentes podem contribuir para a correção de assimetrias passadas, equilibrar o unilateralismo estadunidense e reforçar o multilateralismo e as instituições internacionais. De forma inovadora, esses países possuem ainda, conforme demonstrado na criação do Novo Banco de Desenvolvimento, a capacidade de articulação direcionada ao desenvolvimento de instituições complementares ao financiamento de projetos de infraestrutura $\mathrm{e}$ desenvolvimento sustentável, que podem ser compreendidas dentro de um processo mais amplo de multipolarização (BATISTA JR, 2016).

Os BRICS contribuem para a perspectiva que se apoia na percepção segundo a qual as bases de poder, a serem equilibradas com noções de legitimidade, estão se alterando, de modo que possibilite que o direito internacional seja edificado sob a consideração de diferentes culturas, transformando-as em conteúdo comum (ONUMA, 2017). Contudo, a base da sua própria legitimidade dependerá da aceitação dos movimentos internos e do contínuo apoio pelos e para os países em desenvolvimento. Embora os BRICS não possuam interesses similares, como é nítido, por exemplo, na esfera da OMC, o apoio desses países 
dentro desta e de outras organizações aos países em desenvolvimento representa um aspecto positivo de mudança e benéfico a todo o sistema multilateral (SKRZYPCZYNSKA, 2015).

A democratização das relações internacionais implica a participação de grandes, médios e pequenos estados, com base na igualdade de direitos, na análise e solução de problemas internacionais de interesse comum (BEDJAOUI, 1979). Embora a democratização internacional tenha sido sempre acompanhada pela tensão de posições conflitantes entre nações poderosas e menos poderosas (RICUPERO, 2003), os entendimentos originais de 1945 devem ser restaurados diante das novas realidades contemporâneas. A dominância por um país ou de grupo de países deve, ao longo do tempo, evoluir para um sistema em que todos os países possam participar, juntamente com outros atores não estatais, nos assuntos internacionais (BOUTROS-GHALI, 1996). Uma vez que as deficiências, em matéria de governança, das organizações internacionais tenham se tornado flagrantes, é necessário o reajuste dos critérios de legitimidade com base na inclusão e na confiabilidade epistêmica (KEOHANE, 2006). Durante séculos, o direito internacional foi o que as principais potências da época diziam o que este era no contexto europeu, e levando na esteira destes países outros países periféricos ao sistema. Não mais pode ser reduzido o direito internacional pós-moderno somente ao que queiram ditar os poderosos do momento: evolui consciência jurídica internacional da humanidade, e aperfeiçoaram-se os modos e os patamares de implementação da juridicidade internacional (CASELLA, 2008). Com a mudança nas contestações de poder no século XXI, daquelas centradas no Ocidente para aquelas multipolares, a necessidade de alcançar legitimidade transcivilizacional vai se tornar ainda maior (ONUMA, 2017). O multilateralismo do presente século deve ser remodelado para atender desafios de um mundo cada vez mais globalizado e transnacional. O multilateralismo convencional não conseguirá cumprir o crescimento das demandas de legitimidade (ZÜRN, 2004).

Enquanto os BRICS mantiverem a ação primordial orientada para a reforma das organizações internacionais, de modo a conferir legitimidade à busca de multipolaridade pelos estados individuais e fornecer formas de compartilhar maiores responsabilidades globais, bem como importante fator de equilíbrio a uma ordem unipolar dentro da qual os Estados Unidos exerçam um papel hegemônico (PAPA, 2014), o processo de democratização ganhará frutos importantes, malgrado todos os desafios existentes. Entretanto, para ser eficaz, o discurso de democratização necessita encontrar espaço fora do campo da retórica, com articulação e projetos conjuntos que ultrapassem a perspectiva BRICS e incorporem os anseios de todos os países, sobretudo dos países em 
desenvolvimento. Nesse contexto, os BRICS, em consonância com a importância conferida às Nações Unidas em suas declarações, igualmente devem impulsionar processos de reforma em outros órgãos da ONU, como no âmbito do ECOSOC, de modo que este venha a agregar e concentrar temas importantes da "Declaração do Milênio", transformando-se em órgão realmente eficaz na liderança normativa e na capacidade analítica dos temas econômicos e sociais.

O estudo das reformas do sistema de governança do Conselho de Segurança das Nações Unidas, do Banco Mundial e do Fundo Monetário Internacional revelou a existência de um consenso segundo o qual essas instituições não poderão mais prosseguir sem conferir uma maior participação dos países em desenvolvimento. Além disso, o fator de equilíbrio, considerado insuficiente para a realização do direito internacional de um modo legítimo (ONUMA, 2017), deve vir acompanhado de ações que estejam em consonância com o direito internacional público que, como um ius pacis (direito de paz), um ius cooperationis (direito da cooperação), um ius progressionis (direito do desenvolvimento) e um ius coexistentiae (direito da coexistência), terá papel fundamental no século XXI, sobretudo no sentido de garantir a paz, ordenar as relações internacionais, fomentar a cooperação entre os estados, estabilizar o sistema internacional, adaptar e transformar a realidade internacional, regular os conflitos, impulsionar a justiça e o desenvolvimento internacional (TERZ; BUELVAS, 2007). O direito internacional, como processo fundamental de regulação de canalização das violências internacionais, uma língua comum indispensável, uma técnica instrumental à serviço dos estados e de todos os atores da sociedade internacional (JOUANNET, 2013), tem papel crucial a desempenhar no contexto pós-moderno, em função da revisão dos modelos vigentes no mundo, nos planos institucional e normativo (CASELLA, 2011).

O movimento consubstanciado na indissociável tríade democratizaçãomultilateralismo-multiculturalismo pode ser compreendido como a essência do sistema internacional do século XXI. Os estudos de relações internacionais e de direito internacional deverão levar em conta a questão da legitimidade das organizações internacionais, bem como de seus processos de reforma, atualizações e adaptações. Com efeito, a superação dos paradigmas do século XX igualmente deve ser aplicada na esfera acadêmica, entre os estudiosos do direito internacional. Como elucida ONUMA (2017) a perspectiva predominante existente no estudo do direito internacional deve esbarrar no questionamento de nossas próprias estruturas cognitivas, justapondo algumas outras visões, contribuindo para a aquisição de um novo horizonte ou uma nova forma de ver o mundo. As perspectivas tradicionais do direito internacional podem ocupar um espaço dentro do qual outras 
perspectivas corroboram com novas e pertinentes teorias. Nesse novo movimento, o direito internacional pós-moderno pode incorporar as linguagens culturais e dialogar com a história nas suas dimensões mais amplas (CASELLA, 2008). Outros aportes interdisciplinares, a depender do objeto em análise, podem igualmente contribuir para a ampliação de horizontes. Malgrado as diferenças conceituais entre direito e relações internacionais, as teorias desenvolvidas no âmbito desta última podem favorecer a compreensão de cenários que inevitavelmente envolvam política e poder. Como ressalta SHAW (2008), embora as relações de poder não estejam incluídas no âmbito dos estudos do direito internacional, a total separação entre política e direito nunca será completa e não importa qual teoria do direito ou da filosofia política é levantada. Entretanto, como adverte KOSKENNIEMI (2002) o projeto de interdisciplinaridade impulsionado nos Estados Unidos deve ser observado com cautela: embora proponha um diálogo entre iguais, acaba prevalecendo a hegemonia na qual as relações internacionais impõem seus métodos e interesses cognitivos sobre o direito internacional. À luz dessa realidade, compreendemos que ambas as áreas do conhecimento deverão se adaptar ao contexto pós-moderno e atualizar suas estruturas à luz do multilateralismo e do contexto multicultural, superando tradições dos séculos passados. As perspectivas predominantes existentes nos estudos do direito internacional e das relações internacionais devem ser sopesadas pela autopercepção da predominância, pelos questionamentos e pela criação de novas teorias que sejam desenvolvidas em ambientes acadêmicos diversos. 


\section{REFERÊNCIAS BIBLIOGRÁFICAS}

ABDENUR, Adriana Erthal; FOLLY, Maiara. O Novo Banco de Desenvolvimento e a institucionalização do BRICS. In: BRICS: estudos e documentos. Brasília: FUNAG, 2015, pp. 79-115.

ABI-SAAB, George. Cours général de droit international public. Recueil des cours: collected courses of the Hague Academy of International Law, vol. 207, 1987.

ACCIOLY, Hildebrando; NASCIMENTO E SILVA, G.E., CASELLA, Paulo Borba. Manual de direito internacional público. 17 edição. São Paulo: Saraiva, 2009.

ACHARYA, Amitav; BUZAN, Barry. On the possibility of a non-Western international relations theory. In: Non-Western international relations theory. Perspectives on and beyond Asia. New York; London: Routledge, 2010, pp. 221-239.

AGO, Roberto. Pluralism and the origins of the international community. Italian Yearbook of International Law, v. III. Nápoles: Editoriale Scientifica, 1978.

AKSAR, YUSUF. International economic law. In: Implementing international economic law: through dispute settlement mechanisms. Dordrecht: Martinus Nijhoff Publishers, nijhoff international trade law series, v. 6, 2011, pp.5-50.

ALEXANDROFF; COPPER, Alan S.; Andrew F. Introduction. In: Rising states, rising institutions: challenges for global governance. Alan S. Alexandroff and Andrew F. Cooper, editors. Baltimore: Brookings Institution Press, 2010.

ALMEIDA, Paulo Roberto. O Brasil e o FMI desde Bretton Woods: 70 anos de história. Revista Direito GV, São Paulo, 10 (2), jul-dez 2014, pp.469-496.

ALVAREZ, Alexandre. Le droit international américain. Son Fondament, sa Nature. Paris: A. Pedone, Éditeur, 1910.

ALVES, Fábio Simão. Dança das cadeiras: a reforma do Conselho de Segurança das Nações Unidas. Brasília: Revista Juca, IRBr, 01 fev, 2009, pp. 68-74.

ALVES, José Ricardo da Costa Aguiar. O Conselho Econômico e Social das Nações Unidas e suas propostas de reforma. Brasília: FUNAG, 2013.

ALVES, Rodrigo M. A difícil governança monetária internacional: o caso das cotas do FMI. Boletim Meridiano 47. Brasília, vol. 13, n. 134, nov-dez., 2012.

AMARAL JÚNIOR, Alberto. Curso de direito internacional público. $2^{\mathrm{a}}$ ed. São Paulo: Atlas, 2011.

AMORIM, Celso. Entre o desequilíbrio unipolar e a multipolaridade: o Conselho de Segurança da ONU no período pós-Guerra Fria. São Paulo: Instituto de Estudos Avançados da Universidade de São Paulo, 1998.

A reforma da ONU. São Paulo: Instituto de Estudos Avançados da Universidade de São Paulo, 1998. 
2010.

“¿Existe realmente el BRIC?”. Economia Exterior, Madrid, $n^{\circ}$ 52, primavera de

ANDREATTA, Filippo. Collective security theory and practice of an institution for peace in the XX century. London: Ph.D. Dissertation. International Relations Department London School of Economics and Political Science, Summer, 1996.

APOLINÁRIO JÚNIOR, Laerte. Formação de coalizões dentro das instituições financeiras internacionais: o caso do Brasil no FMI e Banco Mundial. Dissertação de Mestrado, Instituto de Relações Internacionais da Universidade de São Paulo, 2014.

ARMIJO, Leslie E; ROBERTS, Cynthia. The emerging powers and global governance: why the BRICS matter. In: Handbook of emerging economies. Ed. Robert E. Looney. London; New York: Routledge, 2014.

ARON, Raymond. Paz e guerra entre as nações. Trad. Sérgio Bath ( $1^{\circ}$ edição). Brasília: Editora Universidade de Brasília; São Paulo: Imprensa Oficial do Estado de São Paulo, 2002.

ARRIBAS, José Juan M. Derecho internacional: bases y tendencias actuales. Madrid: Entinema, 2007.

BAENA SOARES, João Clemente. Breves considerações sobre a reforma da ONU. In: Reforma da ONU. IV Conferência Nacional de Política Externa e Política Internacional: O Brasil no mundo que vem por aí. Brasília: FUNAG, 2010, pp. 7-26.

BAER, Monica et. al. Os desafios à reorganização de um padrão monetário internacional. CEBRAP/FUNAG /SGPL/PNUD. Revista Economia e Sociedade, n. 4, 1994, pp. 79-126.

BATISTA JR., Paulo Nogueira. Brics - O Novo Banco de Desenvolvimento. Estudos Avançados, São Paulo, v. 30, n. 88, dec. 2016, pp. 179-184.

. Os BRICS no FMI e no G20. In: O Brasil, os BRICS e a agenda Internacional. José Vicente de SÁ PIMENTEL (org.), 2ª ed. Brasília: FUNAG, 2013, pp. 463-472.

. BRICS: a new monetary fund and a new development Bank. In: Brazil in BRICS. Rio de Janeiro: Capax Dei, 2015, pp. 31-36.

. Mesa redonda na FIESP. In: Debatendo o BRICS / José Vicente de Sá Pimentel (Org.). Brasília: FUNAG, 2013.

BAUMANN, Renato. Os BRICS e o G-20 Financeiro. In: O Brasil, os BRICS e a agenda internacional. José Vicente de SÁ PIMENTEL (org.), 2a ed. Brasília: FUNAG, 2013, pp 293-308.

et al. BRICS: estudos e documentos. Brasília: FUNAG, 2015.

BEDJAOUI, Mohammed. International law: achievements and prospects. Paris: UNESCO, 1991.

. Problèmes recents de succession d'États dans les États nouveaux. Recueil des cours. Hague Academy of International RCADI, tome 13, 1970-II. 
Towards a new international economic order. Paris: UNESCO; New York: Holmes \& Meier Publishers, 1979.

BERNES, Thomas A. IMF quota and governance reform: political impulse needed for progress on reform process. CIGI. Disponível em: http://www.cigionline.org/publications/2013/7/imf-quota-andgovernance- reform-politicalimpulse-needed-progress-reform-process. Acesso em 28 de outubro de 2017.

BERTELSMANN-SCOTT, Talitha; FRIIS, Canelle; PRINSLOO, Cyril. Making sustainable development the key focus of the BRICS New Development Bank. South African Institute of International Affairs, May, 2016.

BERTRAND, Maurice. À propos de la réforme du Conseil de sécurité. Études internationales, vol. 30, $\mathrm{n}^{\circ} 2,1999$, pp. 413-422.

Some reflections on reform of the United Nations. Joint Inspection Unit. Bertrand Report. Document JIU/REP/85/9. Document A/40/988, 1985. Geneva: Nações Unidas, 1985.

BHATTACHARYA. Amar; ROMANI, Mattia; STERN, Nicholas. Infrastructure for development: meeting the challenge. Policy paper. Centre for Climate Change Economics and Policy Grantham Research Institute on Climate Change and the Environment, June 2012.

BIDWAI, Praful. The emerging economies and climate change: A case study of the BASIC grouping. Critical perspectives on emerging economies, TNI Working Papers, 2014.

BIERRENBACH, Ana Maria. $O$ conceito de responsabilidade de proteger e o direito internacional humanitário. Brasília: Fundação Alexandre de Gusmão, 2011.

BIJOS, Leila; GUILHON, Erick P. Brics: uma alternativa de poder? Londrina: Revista do Direito Público, vol. 9, n.1, jan./abr. 2014, pp. 9-54.

BLOCK, Fred L. Los orígenes del desorden económico internacional: la política monetaria internacional de los Estados Unidos, desde la Segunda Guerra Mundial hasta nuestros días. Ciudad de Mexico: Fondo de Cultura Económica, 1980.

BLUM, Yehuda Z. Proposals for UN Security Council reform. The American Journal of International Law, Vol. 99, No. 3, Jul., 2005, pp. 632-649.

BOBBIO, Norberto. Dicionário de política.11. ed. Brasília: Editora UnB, 1998.

BOCAYUVA, Pedro C. C. et al. Mecanismos de cooperação entre cidades no âmbito dos BRICS. Rio de Janeiro: BRICS Policy Center / Centro de Estudos e Pesquisa BRICS, 2011.

; SANTOS JÚNIOR, Sérgio Veloso. Cidades-BRICS e o fenômeno urbano global. Carta Internacional, v. 6, n 2, 2011.

BORGHI, Elisa; VILlA, Matteo; VILlAFRANCA. La Sfida Dei Brics Al Sistema Di Bretton Woods. Osservatorio Di Politica Internazionale, n. 114, 2015.

BOUTROS-GHALI, Boutros. An agenda for democratization. New York: United Nations, 1996. 
BROWN, Bartram. Multiculturalism and the Bretton Woods Institutions. In: Multiculturalism and international law. Essays in Honour of Edward McWhinney. Boston: Martinus Nijhoff Publishers, 2009.

BUENO, Elen de Paula. O construtivismo nas relações internacionais. Portal Mundo RI, 05 maio de 2006. Disponível em: http://www.mundori.com/artigosAntigos/detalhes/548. Acesso em: 12 de outubro de 2016.

; OLIVEIRA, Victor Arruda P. El Congreso de Panamá (1826) y los orígenes del derecho internacional en latinoamérica. Madrid: Anuário Hispano-luso-americano de derecho internacional, vol. 22, 2015, pp. 287-318.

BUIRA, Ariel. Las instituciones de Bretton Woods: ¿gobierno sin legitimidad? EconomíaUNAM, vol. 4, nº 10, 2007.

CALVO, Carlos. Derecho international. Teórico e prático. De Europa e América. Paris: D'Amyot Diplomatique, 1868.

CANRONG, Jin. Mesa redonda na FIESP. In: Debatendo o BRICS / José Vicente de Sá Pimentel (Org.). Brasília: FUNAG, 2013.

CAO-HUY, Thuan. Droit et relations internationales, 1983. Disponível em: https://www.u-picardie.fr/curapp-revues/root/13/caohuy.pdf. Acesso em 12 de maio de 2016.

CAPINZAIKI, Marília Romão. A crise financeira internacional e o poder americano: influências sobre o alcance da reforma do FMI. Revista Aurora, v.6. n.1, jul-dez., 2012, pp.57-70.

CAPORASO, James A. International relations theory and multilateralism: the search for foundations. International Organization, vol. 46, Issue 03, June 1992, pp. 599-632.

CARON, David D. The legitimacy of the collective authority of the Security Council. The American Journal of International Law, vol. 87, n. 4, Oct, 1993, pp. 552-588.

CARR, Edward H. The twenty years' crisis 1919-1939: an introduction to the study of international relations. London: Macmillan, 1946.

CARREAU, Dominique; JUILLARD, Patrick. Droit international économique. $4^{\mathrm{a}} \mathrm{ed}$. Paris: L.G.D.J, 1998.

CARVALHO, Evandro Menezes de. BRICS Plus and the future of the BRICS agenda. China Today, 31 Aug. 2017. Disponível em: http://www.chinatoday.com.cn/english/economy/2017-08/31/content_745375.htm. Acesso em: 2 de setembro de 2017 .

Diplomacia e multilinguismo no direito internacional. Revista Brasileira de Política Internacional, n.49, v. 2, 2006, pp. 178-195.

CARVALHO, Fernando J. Cardim. O G-20 e a reforma do sistema financeiro: possibilidades e limitações. In: As transformações no sistema financeiro internacional. Brasília: IPEA, 2012, v. 1, pp. 15-30. 
. A crise econômico-financeira de 2007/2008, o G20 e as opções para o Brasil. In: V Conferência nacional de política externa e política internacional: o Brasil no mundo que vem aí. Brasília: FUNAG, 2010, pp. 69-82.

CASELLA, Paulo Borba. Fundamentos do direito internacional pós-moderno. São Paulo: Quartier Latin, 2008.

Direito internacional no tempo antigo. São Paulo: Atlas, 2012.

BRIC: Brasil, Rússia, Índia, China e África do Sul: uma perspectiva de cooperação internacional. São Paulo: Atlas, 2011.

. Reforma da ONU, pós-Kelsen. In: Reforma da ONU. IV conferência nacional de política externa e política internacional: o Brasil no mundo que vem por aí. Brasília: FUNAG, 2010, pp. 143-210.

Direito internacional dos espaços. São Paulo: Atlas, 2009.

Fundamentos e perspectivas do direito internacional pós-moderno. Revista da Faculdade de Direito da Universidade de São Paulo v. 101, jan./dez. 2006, pp. 433-466.

CASSAN, Hervé. Le consensus dans la pratique des Nations Unies. In: Annuaire français de droit international, v.20, 1974, pp. 456-485.

CASSESE, Antonio. International law. $2^{\circ}$ edition. Oxford: Oxford University Press, 2005.

CASTRO, Thales. Conselho de Segurança da ONU: unipolaridade, consensos e tendências. Curitiba: Juruá, 2007.

CELLI JUNIOR, Umberto. Teoria geral da integração: em busca de um modelo alternativo. In: Blocos econômicos e integração na América Latina, África e Ásia. MERCADANTE, Araminta de Azevedo; CELLI JUNIOR, Umberto; ARAÚJO, Leandro Rocha de (org. Curitiba: Juruá, 2006.

CHUN, Kwang Ho. Are there prospects of the BRICs being the next Superpower? In: The BRICs superpower challenge: Foreign and Security Policy Analysis. Surrey-UK, Ashgate, 2013.

COELHO, Jaime C. Reformando as instituições financeiras multilaterais (passado e presente): banco mundial e fundo monetário internacional. In: As transformações no sistema financeiro internacional. Brasília: IPEA, 2012, v. 1, pp. 605-648.

; CAPINZAIKI, Marília R. Desdobramentos da crise financeira de 2007-08:

reforma da arquitetura financeira tradicional e inovações no desenho institucional do regime financeiro internacional. Carta Internacional, vol. 9, n.1, jan-jun, 2014, pp. 144-160.

COHEN, Benjamin. Bretton Woods System. Prepared for the Routledge Encyclopedia of International Political Economy. Disponível em: http://www.polsci.ucsb.edu/faculty/cohen/inpress/bretton.html. Acesso em: 22 de março de 2017.

COLLIARD, Claude-Albert. Institutions des relations internacionales. $9^{\mathrm{a}}$ ed. Paris: Dalloz, 1990. 
COOPER, Andrew F. The BRICS' New Development Bank: shifting from material leverage to innovative capacity. Global Policy, University of Durham, 2017, pp.1-10.

; FAROOQ, Asif B. Testing the club dynamics of the BRICS: The New Development Bank from conception to establishment. International Organisations Research Journal, v. 10, n. 2, 2015. Disponível em: http://www.brics.utoronto.ca/biblio/iorj-2015-02cooper-farooq.pdf. Acesso em 22 de abril de 2016.

COOPER, David. Challenging contemporary notions of middle power influence: implications of the proliferation security initiative for "Middle Power Theory". Foreign Policy Analysis 7, 2011, 317-336.

COMPARATO, Fábio Konder. A Organização das Nações Unidas no quadro da futura sociedade política mundial. In: Reforma da ONU. IV Conferência Nacional de Política Externa e Política Internacional: o Brasil no mundo que vem por aí. Brasília: FUNAG, 2010, pp. 113-142.

CONING, Cedric; MANDRUP, Thomas; ODGAARD, Liselotte. Introduction. In: The BRICS and coexistence: an alternative vision of world order. New York: Routledge, 2015.

CORRÊIA, Sônia. Potências emergentes: Seria a sexualidade e os direitos humanos um assunto secundário? Sur 24, Revista Internacional de Direitos Humanos, vol. 11, n. 20, junho de 2014, pp. 171-183.

COZENDEY, Carlos Marcio. Visão ou Miragem? Banco de Desenvolvimento e Arranjo de Reservas no Horizonte dos BRICS. In: BRICS: estudos e documentos. Brasília: FUNAG, 2015, pp. 115-138.

BRIC a BRICS em um mundo em transição. In: O Brasil, os BRICS e a agenda internacional, $2^{\circ}$ ed. Brasília: FUNAG, 2013, pp. 157-170.

Debatendo os BRICS: mesa-redonda no palácio Itamaraty. Org. José Vicente de Sá Pimentel. Brasília: FUNAG, 2013.

COX, Robert W. Rumo a uma conceituação pós-hegemônica da ordem mundial: reflexões sobre a relevância de Ibn Kaldun. In: Governança sem governo: ordem e transformação na política mundial. Rosenau, James N. e Czempiel, Ernst-Otto. Brasilia: Ed. UnB e São Paulo: Imprensa Oficial do Estado, 2000, pp. 183-218.

CRETELLA NETO, José. Curso de direito internacional econômico. São Paulo: Saraiva, 2012.

Origem e necessidade das organizações internacionais. In: Direito internacional: homenagem a Adherbal Meira Mattos. Paulo Borba CASELLA e André de Carvalho RAMOS (org.). São Paulo: Quartier Latin, 2009, pp. 452-479.

. Teoria geral das organizações internacionais. $3^{\text {a }}$ Ed. São Paulo: Saraiva, 2013.

CUSSON, Gabrielle; CULPI, Ludmila. The BRICS' New Development Bank: a China-led challenge to Western Hegemony. In: Reconfiguration of the Global South: Africa and Latin America and the Asian century. London: Routledge, 2016, pp. 107-124.

DAMICO, Flavio. Antecedentes: do acrônimo de mercado à concertação políticodiplomática. In BRICS, estudos e documentos. Brasília: FUNAG, 2015. 
BRICS: o novo "lugar" do conceito. In: O Brasil, os BRICS e a agenda internacional. José Vicente de SÁ PIMENTEL (coord.), 2º ed. Brasília: FUNAG, 2013, pp.375-398.

DAMICO, Flavio. Mesa Redonda no Palácio do Itamaraty, 27 de abril de 2012. In: Debatendo o BRICS / José Vicente de Sá Pimentel (Org.). Brasília: FUNAG, 2013.

DELMAS-MARTY, Mireille. Les forces imaginantes du droit (II) - Le pluralisme ordonné. Paris: Seuil, 2006.

DINH, Ngyuen Quoc et al. Droit international public. 8a ed. Paris: L.G.D.J, 2009.

DUGGAN, Niall. BRICS and the evolution of a new agenda within global governance. In: The European Union and the BRICS: complex relations in the era of global governance. London: Springer, 2015, pp. 11-26.

DUPUY, René-Jean. Etat et organization internationale. In: Manuel sur les organisations internationales. $2^{\mathrm{a}}$ ed. London/Boston/Dorbrecht: Martinus Nijhoff publishers, 1998.

$\frac{}{1997 .}$. Mondialisation et dédoublement du monde. Études internationales (Tunis), n. 63,

ELIAS, Taslim Olawale. Africa and the development of international law. Dordrecht: martinus nijhoff publishers, 1988.

ERDAĞ, Ramazan. How many is greater than five? A comprehensive model proposal for the United Nations Security Council. 72nd Midwest Political Science Association (MPSA) Annual Conference, April 3-6, 2014, Chicago, IL, USA. Alternatives turkish journal of international relations, v. 13, n. 4, Winter 2014. Disponível em: www.alternetivesjournal.net. Acesso em 6 de janeiro de 2017.

ESTEVES, Paulo; ZOCCAL, Geovana; TORRES, Gabriel. Os novos bancos mutilaterais de desenvolvimento e as salvaguardas socioambientais. Rio de Janeiro. PUC. BRICS Policy Center, BPC Policy Brief, v. 6. n. 03, outubro-novembro, 2016.

FALK, Richard A. Legality and legitimacy: necessities and problematics of exceptionalism. In: Legality and legitimacy in global affairs. New York: Oxford University Press, 2012.

The new states and the international legal order. Hague: Hague Academy of International Law, Recueil de Cours, 1966.

FASSBENDER, Bardo. All illusions shattered? looking back on a decade of failed attempts to reform the UN Security Council. Max Planck Yearbook of United Nations Law, 7, 2003, pp. 183-218.

- Pressure for Security Council reform. From the cold war to the $21^{\text {st }}$ century. London: Lynne Rienner, 2004.

FERNANDES, Elieti Biques. O fórum de diálogo IBAS sob uma perspectiva teóricoconceitual. Rev. Século XXI. Porto Alegre, v.3, n.2, 2012.

FOCH, Arhur. Explaining the G7 and G10's influence on World Bank decisions: The role of formal and informal rules of governance. Documents de travail du Centre d'Economie de la Sorbonne, 2013. 
FONSECA JR, Gelson. A Legitimidade e outras questões internacionais. São Paulo: Paz e Terra, 1998

BRICS: notas e questões. In: O Brasil, os BRICS e a agenda internacional. $2^{\mathrm{a}}$ edição. Brasília: FUNAG, 2013, pp 21-46.

FREIESLEBEN, Jonas Von. Reform of the Security Council. In: managing change at the United Nations, Center for UN Reform of the Security Council, April 2008. Disponível em: http://www.centerforunreform.org/node/23. Acesso em 03 de outubro de 2016.

FUJITA, Edmundo Sussumu. O Brasil e o Conselho de Segurança (notas sobre uma década de transição: 1985 - 1995). Parcerias Estratégicas, vol. 1, n. 2, dezembro de 1996.

GARWOOD-GOWERS, Andrew. The BRICS and the responsibility to protect in Libya and Syria. In: The BRICS and coexistence: an alternative vision of world order. New York: Routledge, 2015.

GEORGIEV, Dencho. Politics or rule of law: deconstruction and legitimacy in international law. European Journal of International Law, 1993, pp. 1-14.

GIANNATTASIO, Arthur R. Capella; CARDOSO, Luís F. de Paiva Baracho. Structural challenges in a multipolar and multicultural global legal era: BRICS' global legal politics beyond cultural and economic partnerships. São Paulo Law School of Fundação Getulio Vargas - DIREITO GV, Research Paper Series - Legal Studies Paper n. 87, 2014.

GILLEY, Bruce; O’NEIL, Andrew. China's rise through the prism of middle powers. In: Middle powers and the rise of China. Washington: Georgetown University Press, 2014, pp.1-22.

GILPIN, Robert. Global political economy. Princeton: Princeton University Press, 2001.

GUIMARÃES, Feliciano Sá. Os burocratas das organizações financeiras internacionais: um estudo comparado entre o Banco Mundial e o FMI. Rio de Janeiro: Editora FGV, 2012.

O controle dos países do G-7 sobre o recrutamento dos burocratas do FMI: o elo perdido das reformas. Revista de Sociologia e Política. Curitiba, vol. 21, n. 48, p.111126, dez. 2013.

GNATH, Katharina; MILDNER, Stormy-Annika; SCHMUCKER, Claudia. G20, IMF, and WTO in turbulent times. Legitimacy and effectiveness put to the test. Berlin: SWP Research Paper, 10, 2012.

GOLD, Joseph. Developments in the law and institutions of international economic relations. The American Journal of International Law, v. 68, n. 4, Oct., 1974, pp. 687-708.

. Legal and institutional aspects of the international monetary system: selected essays, vol. II. Washington: International Monetary Fund, 1984.

GORDON, Gretchen; TONI, Ana; KWEITEL, Juana. O Banco dos BRICS precisa de uma estratégia sólida e participativa para o desenvolvimento sustentável. Open Democracy, 19 de abril de 2017. Disponível em: https://www.opendemocracy.net/democraciaabierta/juana-kweitel-ana-toni-gretchengordon/o-banco-dos-brics-precisa-de-uma-estrat-gia. Acesso em 21 de abril de 2017. 
GREWE. Wilhelm. The epochs of international law. Translated and revised by Michael Byers, do original Epochen der Völkerrechtsgeschichte. Berlin: Walter de Grutyer, 2000.

GRIFFITH-JONES, Stephany. A BRICS Development Bank: a dream coming true? Discussion papers. United Nations Conference on Trade and Development, n. 215, March, 2014.

Uma nova arquitetura como bem público global. In: Arquitetura assimétrica: o espaço dos países emergentes e o sistema financeiro internacional. São Paulo: Fundação Konrad Adenauer, 2002, pp. 23-54.

. The Asian Infrastructure Investment Bank: changing development finance architecture. In: Multilateral development banks in the 21st century. Three perspectives on China and the Asian Infrastructure Investment Bank. London: Overseas Development Institute, 2015, pp.8-14.

GUGGENHEIM, Paul. Traité de droit international public: avec mention de la pratique internationale et suisse. T. I, Geneva: Librairie de l'Université, 1953.

HAAS, Ernst B. Types of collective security: an examination of operational concepts. The American Political Science Review, v. 49, n. 1, Marc, 1955, pp. 40-62.

HAJNAL, Peter. The G8 system and the G20: evolution, role and documentation. London: Ashgate, 2007.

HALLDING, Karl et al. Together alone. BASIC countries and the climate change conundrum. Copenhagen: Norden, 2011.

HASSLER, Sabine. Reforming the UN Security Council membership. The illusion of representativeness. Abingdon: Routledge, 2013.

HERNDL, Hurt. Reflections on the role, functions and procedures of the Security Council of the United Nations. Recueil des cours. Hague Academy of International Law, v. 206, 1987, pp. 289-395.

HERZ, Mônica. O Brasil e a reforma da ONU. Lua Nova, São Paulo, nº 46, 1999.

HOBSBAWN, Eric. Era dos extremos. O breve século XX. 1914-1991. São Paulo: Companhia das Letras, 1995.

HOFFMANN, Stanley. An american social science: international relations. Daedalus. v.106. n. 3.Summer, 1977, pp. 41-60.

HOLBRAAD, Carsten. The role of middle powers. Cooperation and Conflict 1, 1971.

HUMPHREY, Chris et. Al. Multilateral development banks in the 21st century. Three perspectives on China and the Asian Infrastructure Investment Bank. London: Overseas Development Institute, 2015.

HURRELL, Andrew. Hegemonia, liberalismos e ordem global: qual é o espaço para potências emergentes? In: Os Brics e a ordem global. Rio de Janeiro: Editora FGV, 2009.

Explaining the resurgence of regionalism in world politics. Review of International Studies, 21, 1995, pp. 331-358. 
; SENGUPTA, Sandeep. Emerging powers, North-South relations and global climate politics. International Affairs, v. 88, 3, 463, 2012.

JORDAAN, Eduard. The concept of a middle power in international relations: distinguishing between emerging and traditional middle powers". Politikon, v. 30, n. 2, 2003, pp. 166-171.

JOUANNET, Emmanuelle. Le droit international. Que sais-je? Paris: PUF, 2013.

Emer de Vattel et l' émergence du droit international classique. Paris: Pedone, 1998.

A century of french international law scholarship. Maine law review, v. 61, 1, 2009, pp. 84-13.

JOYNER, Christopher C. International law in the 21st century. Rules for global governance. Oxford/New York: Rowman little field publishers, 2005.

KÄKÖNEN, JYRKI. BRICS as a new constellation in international relations? In: Mapping BRICS Media, edited by K. Nordenstreng and D. Thussu. London: Routledge, 2015, pp. 25-41.

KELSEN, Hans. Collective security and collective self-defense under the Charter of the United Nations. The American Journal of International Law, v. 42, n. 4, 1948, pp. 783-796.

The principle of sovereign equality of states as a basis for international organization. The Yale Law Journal, v. 53, n. 2, 1944, pp. 207-220.

International law studies. Collective security under international law. Washington: United States Government Printing Office, 1957.

KEOHANE, Robert $\mathrm{O}$. The demand for international regimes. International organization, v. 36, n.2, International Regimes, Spring, 1982, pp. 325-355.

; MARTIN, Lisa L. The promisse of institutionalism theory. International Security, v. 20, n. 1, Summer, 1995, pp. 39-51.

; NYE, Joseph S. Power and interdependence revisited. International Organization, v. 41, n. 4, Autumn, 1987, pp. 725-753.

. After hegemony: cooperation and discord in the world political economy. Princeton: Princeton University Press, 1984.

. The contingent legitimacy of multilateralism. In: Multilateralism under challenge? Power, international order, and structural change New York: Social Science Research Council/ United Nations University, 2006.

KENNEDY, David. Les clichés revisité: le droit international et la politique. Paris: Université de Paris II, Six conferences, february/march, 1999.

KISSINGER, Henry. Diplomacia. Tradução Saul Gefter e Ann Mary Perpétuo. São Paulo: Saraiva, 2012. 
KOHEN, Marcelo. Manifeste pour le droit international du XXIe siècle. In : L'ordre juridique international, un système en quête d'équité et d'universalité. Coord. Liber Amicorum; Georges Abi-Saab. Haia: Martinus Nijhoff Publishers, 2001.

KOLB, Robert. Considérations sur le droit international public des anciennes cultures extraeuropénnes. In: The roots of international law / Les fondements du droit: liber amicorum Peter Haggenmacher. Edité par Pierre-Marie Dupuy e Vincen Chetail, v. 11. Boston: Martinus Nijhoff Publishers, 2014.

Mondialisation et droit international. In: Relations Internationales. Paris: Presses Universitaires de France, 2005, pp. 69-86.

KOROMA, Abdul G. International law and multiculturalism. In: Multiculturalism and international law. Essays in honour of Edward McWhinney. Boston: Martinus Nijhoff Publishers, 2009.

KOSKENNIEMI, Martti. Georges Abi-Saab. Repetition as reform: Cours general de droit international public. European Journal of International Law. Issue v. 9, n. 2, 1998.

The Gentle civilizer of nations. The rise and fall of international law 1870-1960. Cambridge: Cambridge University Press, 2002.

. Carl Schmitt, Hans Morgenthau, and the image of law in international relations. In: The role of law in international politics. Essays in international relations and international law. New York: Oxford University Press, 2000.

KINDLEBERGER, Charles P. A financial history of Western Europe. London: George Allen e Unwin, 1984.

KIRTON, John. From G7 to G20: capacity, leadership and normative diffusion in global financial governance. Paper prepared for a panel on "expanding capacity and leadership in global financial governance: from g7 to g20," international studies association annual convention, March 1- 5, 2005, Hawaii. Presented at 3:45-5.30 pm on Wednesday, March 2. Draft of February 20, 2005.Disponível em: www.g8.utoronto.ca/scholar/.../kirton_isa2005.pdf. Acesso em 18 de outubro de 2015.

KÖCHLER, Hans. The voting procedure in the United Nations security council examining a normative contradiction in the UN charter and its consequences on international relations In: Democracy and the international rule of law. Propositions for an alternative world order. Selected Papers Published on the Occasion of the Fiftieth Anniversary of the United Nations. Vienna and New York: Springer, 1995, pp. 85-116.

The United Nations Organization and global power politics: The antagonism between power and law and the future of world order. Chinese Journal of International Law, v. 5, n. 2, 2006.

KRANZ, Jersy. La prise de décisions dans les organisations internationales et le nouvel ordre économique international. Archiv des Völkerrechts, 20, 3, 1982, pp. 281-300.

KRISHNASWAMY, Srinivas; KWEITEL, Juana. Is the BRICS bank tooled for sustainable development? Disponível em: https://www.chinadialogue.net/blog/9315-Isthe-BRICS-bank-tooled-for-sustainable-development-/en. Acesso em 28 de abril de 2017. 
KU, Charlotte; WEISS, Thomas G.. Introduction: the nature and methodology of the fields. In: Toward understanding global governance: The International Law and International Relations Toolbox. ACUNS: Reports and Paper, n. 2, 1998.

KUPA, Jacques. Coopération Sud-Sud et tripartite dans l'espace francofone, directeur Jacques Kupa. Paris: Organisation internationale de la Francophonie, 2014.

LACHS, Manfred. O Direito internacional no alvorecer do século XXI. Estudos avançados, v.8, n.21, São Paulo May/Aug 1994. Do original: Le droit international à l'aube du XXi siècle, R.G.D.I.P., n. 3, 1992, pp. 529-550.

LANGENHOVE, Luk Van; ZWARTJES Marieke; PAPANAGNOU, Georgios. Conceptualising regional leadership: the positioning theory angle. In: Global and regional leadership of BRICS countries. United Nations Universities Series on Regionalism, v. 11, 2016, pp.13-28.

LARIONOVA, Marina; SHELEPOV, Andrey. Is BRICS institutionalization enhancing its effectiveness? In: The European Union and the BRICS: complex relations in the era of global governance. London: Springer, 2015, pp. 39-53.

LATINO, Agostina. The New Development Bank: Another BRICS in the wall? In: Accountability, transparency and democracy in the functioning of Bretton Woods institutions. London: Springer International Publishing, 2017, pp. 47-69.

LECHINI, Gladys. La cooperación Sur-Sur y la búsqueda de autonomía en América Latina: ¿Mito o realidad? GERI - UAM Relaciones Internacionales, n. 12, octubre de 2009, pp. 55-81.

LEECH, Dennis; LEECH, Robert. Voting power in the Bretton Woods institutions. Homo Oeconomicus 22, 4, 2005, pp. 605-627.

LESAGE, Dries; GRAAF, Thijs Van de. Analytical framework and findings. In: Rising powers and multilateral institutions. London: Palgrave Macmillan UK, 2015.

LI, Ruogo. Reform of the international monetary system and internationalization of the Renminbi. Beijing: World Scientific Publishing Co Pte Ltd, 2015.

LIMA, Maria Regina Soares de. Notas sobre a reforma da ONU e o Brasil. In: Reforma da ONU. IV Conferência Nacional de Política Externa e Política Internacional: o Brasil no mundo que vem aí. Seminário sobre a Reforma da ONU. Brasília: FUNAG, 2010.

; CASTELAN, Daniel Ricardo. O Brasil, os BRICS e a institucionalização do conflito internacional. In: O Brasil, os BRICS e a agenda internacional, $2^{\circ}$ ed. Brasília: FUNAG, pp.251-266.

. Brasil e polos emergentes do poder mundial: Rússia, Índia, China e África do Sul. In: O Brasil e os demais BRICs - Comércio e Política. Brasília: CEPAL. Escritório no Brasil/IPEA, 2010, pp. 155-179.

LIN, Justin Yifu; FARDOUST, Shahrokh; ROSENBLATT, David. Reform of the international monetary system: a jagged history and uncertain prospects. Policy Research Working Paper 6070, World Bank, 2012. 
LISTER, Frederick K. Decision-making strategies for international organizations: the IMF model, v. 20, n.4. Graduate School of International Studies, University of Denver, Denver, 1984.

LORCA, Arnulf B. Universal international law: nineteenth-century histories of imposition and appropriation. Havard International Law Journal, v. 51, n. 2, summer 2010.

LUCK. Edward C. Reforming the United Nations: lessons from a history in progress. International Relations Studies and the United Nations Occasional Papers, n.1, 2003.

LUMUMBA-KASONGO, Tukumbi. Brazil, Russia, India, China, and South Africa (BRICS) and Africa: new projected developmental paradigms. Africa Development, v. XL, n. 3, 2015, pp. 77-95.

MACEDO, Leonardo Andrade. $\mathbf{O}$ fundo monetário internacional e seus acordos standby. Belo Horizonte: Editora Del Rey, 2007.

MACQUEEN, Benjamin. Muslim states and reform of the United Nations Security Council. Journal of Middle Eastern and Islamic Studies (in Asia) v. 4, n. 3, 2010.

MAGUIRE, Rowena. The rise of the BASIC group within the international climate regime. In: The BRICS and coexistence: an alternative vision of world order. New York: Routledge, 2015.

MALONE, David M. The UN Security Council: from the Cold War to the $21^{\text {st }}$ century. London: Lynne Rienner, 2004

MCDONALD, Kara C; PATRICK Stewart M. UN Security Council enlargement and U.S. interests. New York: Council on Foreign Relations, Special Report n. 59, 2010.

MACFARLANE, Neil. The 'R' in BRICs: is Russia an emerging power? International Affairs, London, v. 82, n. 1, pp.41-57, jan., 2006.

MARINO, Rich. The future BRICS. A synergistic economic alliance or business as usual. London: PALGRAVE MACMILLAN, 2014.

MARTYNOV, Boris F. BRIC: cooperation perspectives in the international security sphere. Cúpula BRIC de Think Tanks: O papel dos BRIC na transformação global no póscrise. Brasília: IPEA, 2010, pp. 11-16.

MEDEIROS, Antonio Paulo C. de. O Desafio da reforma da ONU. In: Reforma da ONU. IV Conferência Nacional de Política Externa e Política Internacional: o Brasil no mundo que vem aí. Seminário sobre a Reforma da ONU. Brasília: FUNAG, 2010, pp. 99-111.

MEDEIROS, Carlos Aguiar de. A China como um duplo polo na economia mundial e a recentralização da economia asiática. Revista de Economia Política, v. 26, n. 3, 103, julhosetembro, 2006, pp. 381-400.

MEIRELLES, Elizabeth de Almeida. O princípio da precaução e o aporto de Guido Fernando Silva Soares. In: Direito internacional, humanismo e globalidade. Guido Fernando Silva Soares, Amicorum Discipulorum Liber. São Paulo: Atlas, 2008, pp. 353372. 
MELLO, Celso de Albuquerque. Curso de direito internacional público. Rio de Janeiro: Renovar, 2000.

MENEZES, Wagner. A ONU e o direito internacional contemporâneo. In: Jornadas de direito internacional público no Itamaraty. Desafios do direito internacional contemporâneo. Brasília: FUNAG, 2007, pp. 325-342.

MERCADANTE, Araminta de Azevedo. Algumas questões específicas do direito internacional: língua dos tratados e reforma da ONU. In: Direito internacional, humanismo e globalidade: Guido Fernando Silva Soares. Paulo Borba CASELLA et. al. (org.). São Paulo: Atlas, 2008, pp. 373-390.

MILANI, Carlos R.S.; SUYAMA, Bianca; LOPES, Laura L. Políticas de cooperação internacional para o desenvolvimento no Norte e no Sul: que lições e desafios para o Brasil? São Paulo: Friedrich Ebert Stiftung, 2013.

MILDNER, Stormy; SILVA-GARBADE, Caroline. Por que a reforma do FMI tem sido tão difícil: os EUA e a União Europeia no FMI. In: Governança global. Rio de Janeiro: Fundação Konrad Adenauer, março 2009, pp. 61-84.

MIRANDA, Luiz Ricardo. O Grupo Banco Mundial e a regulação internacional do financiamento de projetos (Project Finance). Tese de Doutorado. Faculdade de Direito da Universidade de São Paulo, 2013.

MITRANY, D. Territorial, ideological, or functional international organisation? In: The functional theory of politics. London: Martin Robertson, 1975.

MOHAN, Rakesh; KAPUR, Muneesh. Emerging powers and global governance: Whither the IMF? IMF Working Paper, 12/219, 2015.

Disponível em: http://www.imf.org/external/pubs/ft/wp/2015/wp15219.pdf. Acesso em $1^{\circ}$ de maio de 2017.

MORIN, Edgar. A cabeça bem-feita: repensar a reforma, reformar o pensamento. Tradução Eloá Jacobina. 8ªed. Rio de Janeiro: Bertrand Brasil, 2003.

MOURA, Gilberto F.G. O Diálogo Índia, Brasil, África do Sul - IBAS: balanço e perspectivas. In: Seminário IBAS. III Conferência Nacional de Política Externa e Política Internacional "O Brasil no mundo que vem aí" - III CNPEPI. Brasília, Alexandre Gusmão, 2008.

MORAES, Rodrigo F.; RIBEIRO, Elton J.J.. De BRIC a BRICS: como a África do Sul ingressou em um clube de gigante. Contexto Internacional, Rio de Janeiro, v. 37, n.1, p.255287, jan/abr 2015.

NAIK, Shraddha. The prospects and challenges for achieving sustainable development goals under the BRICS-New Development Bank (NDB). International Research Journal of Interdisciplinary \& Multidisciplinary, v.3, June 2017, pp. 143-148.

NEWMAN, Edward; THAKUR, Ramesh; TIRMAN; John. Introduction. In: Multilateralism under challenge? Power, international order, and structural change. New York: Social Science Research Council/ United Nations University, 2007. 
NÓBREGA, Kenneth Felix Haczynski da. BRICS: de Fortaleza a Goa. Cadernos de Política Exterior / Instituto de Pesquisa de Relações Internacionais, v. 2, n. 4, dez. 2016, pp. 29-56.

NYE Jr, Joseph S. Cooperação e conflito nas relações internacionais. São Paulo: Editora Gente, 2009.

O paradoxo do poder Americano. Por que a única superpotência do mundo não pode prosseguir isolada. São Paulo: editora Unesp, 2002.

OCAMPO, Jose Antonio. Os direitos especiais de saque e a reforma do sistema monetário internacional. In: As transformações no sistema financeiro internacional. Brasília: IPEA, 2012, v. 2, pp. 573-604.

O’NEILL, Jim. Building better economic BRICs. Global Economics Paper, n. 66, 30 nov. 2001. Disponível em: http://www.goldmansachs.com/our-thinking/archive/archivepdfs/build-better-brics.pdf. Acesso em: 22 de fevereiro de 2015.

ONUMA, Yasuaki. International law in and with international politics: the functions of international law in international society. European Journal of International Law, v. 14, n. 1, 2003, pp. 105-149.

A Transcivilizacional perspective on international law - questioning prevalent cognitive frameworks in the emerging multi-polar and multi-civilizational world of the twenty-first century. Boston: Martinus Nijhoff Publishers, 2009.

Direito internacional em perspectiva transcivilizacional. Questionamento da estrutura cognitiva predominante no emergente mundo multipolar e multicivilizacional do século XXI. CASELLA; Paulo Borba; NINOMIYA, Masato (Org.). Belo Horizonte: Arraes, 2017.

ORĂŞTEAN, Ramona; MĂRGINEAN, Silvia. International monetary system: between crisis and reform. Theoretical and Applied Economics, v. XX, n. 8 (585), 2013, pp. 137-147.

OURO-PRETO, Affonso Celso de. Nova configuração de poder. In: O Brasil, os BRICS e a agenda Internacional. José Vicente de SÁ PIMENTEL (org.), 2a ed. Brasília, FUNAG, 2013, pp. 99-116.

PABIS, Jonatas Luis. Acorrentando Gúlliver: a atuação dos BRICS nas negociações sobre agricultura da Rodada Doha da OMC. Anuario Mexicano de Derecho Internacional, v. XV, 2015, pp. 659-699.

PACHECO, Silvestre E. Rossi. Multilateralismo e cooperação Sul-Sul: o Fórum de Diálogo IBAS no marco das relações internacionais entre Brasil, Índia e África do Sul. Tese (doutorado) - Pontifícia Universidade Católica de Minas Gerais, Programa de PósGraduação em Direito, 2010.

PANDIT, B.L. The global financial crisis and the Indian economy. New Delhi: Springer, 2015.

PAPA, Mihaela. BRICS as a global legal actor: from regulatory innovation to BRICS Law? Rivista di diritto pubblico italiano, comparato, europeo, 2014.

BRICS's pursuit of multipolarity: response in the United States. Fudan Journal of Hum.Soc.Sci, v. 7, n.3, 2014, pp. 363-380. 
PATRIOTA, Antonio de Aguiar. O Conselho de Segurança após a Guerra do Golfo: a articulação de um novo paradigma de segurança coletiva. Brasília: FUNAG, 2010.

. Os Brics são hoje os EUA da época do Rio Branco. Rio de Janeiro: Folha de São Paulo, 10 de janeiro de 2012.

PAULUS, Andreas A. Law and politics in the age of globalization. European Journal of International Law, v. 11, n.2, 2000, pp. 465-472.

PELLET, M. Alain. Peut-on et doit-on contrôler les actions du conseil de sécurité? Le chapitre VII de la Charte des Nations Unies: 50e anniversaire des Nations Unies. Colloque de Rennes. Paris: Pedone, 1995.

PEREIRA, Antonio Celso Alves. A reforma das Nações Unidas e o sistema internacional contemporâneo. In: Jornadas de direito internacional público no Itamaraty. Desafios do direito internacional contemporâneo. Brasília: FUNAG, 2007, pp. 21-78.

PEREIRA, João Márcio Mendes. Banco Mundial: concepção, criação e primeiros anos (1942-60). Varia História, Belo Horizonte, v. 28, n. 47, jan/jun, 2012, pp. 391-419.

PETERS, Anne. Le cheminement historique des organisations internationales: entre technocratie et démocratie. In: The roots of international law / Les fondements du droit: liber amicorum Peter Haggenmacher. Edité par Pierre-Marie Dupuy e Vincen Chetail, v. 11. Boston: Martinus Nijhoff Publishers, 2014, pp. 487-529.

PIMENTEL, Fernando. O BRICS e a construção de uma nova arquitetura financeira internacional. In: O Brasil, os BRICS e a agenda internacional. José Vicente de SÁ PIMENTEL (org.), $2^{\text {a }}$ ed. Brasília: FUNAG, 2013, pp. 473-494.

. Mesa redonda na FIESP. In: Debatendo o BRICS / José Vicente de Sá Pimentel (Org.). Brasília: FUNAG, 2013.

PIOCH, Martin. BRICS in world trade. Can the rise of (re-) emerging powers challenge the international trading system? PRIMO Working Paper Series Working Paper, n. 3, September 2016.

POSNER, Eric; SYKES, Alan O. Voting rules in international organizations. University of Chicago: public law \& legal theory working paper, n. 458, 2014, pp.1-23.

PRADEL, Nicolas. Pays émergents et droit international: l'enjeu de l'adaptation. L'Observateur des Nations Unies, Association française pour les Nations Unies, 2013, v. 33, 2012.

RAMOS, Leonardo et. al. A governança econômica global e os desafios do G-20 pós crise financeira: Análise das Posições de Estados Unidos, China, Alemanha e Brasil. Revista Brasileira de Política Internacional. Brasília, vol 2, n. 55, 2012, pp.10-27.

REISEN, Helmut. Will the AIIB and the NDB help reform multilateral development banking? Global Policy, v. 6, Iss. 3, pp. 297-304.

REIS, Maria Edileuza Fontenele. BRICS: surgimento e evolução. In: O Brasil, os BRICS e a agenda internacional, $2^{\circ}$ ed. Brasília: FUNAG, 2013, pp. 47-72. 
Debatendo os BRICS: mesa-redonda no palácio Itamaraty. Org. José Vicente de Sá Pimentel. Brasília: FUNAG, 2013.

REIS, Gabriel Valente. Direitos civis e políticos nos BRICS e África do Sul: um estudo de direito comparado. Revista da Faculdade de Direito da Universidade Federal de Minas Gerais, n. 58, 2011, pp. 187-218.

REUS-SMIT, Christian. International law. In: Globalization of world politics: an introduction to international relations. New York: Oxford University Press, 2008, pp. 280293.

REYES, Alma Arámbula. Consejo de Seguridad de Naciones Unidas. Centro de documentación, información y análisis. Camara de Diputados. Ciudad de Mexico, 2008.

REWIZORSKI, Marek. Participation of the European Union and the BRICS in the G20. In: The European Union and the BRICS: complex relations in the era of global governance. London: Springer, 2015, pp. 57-78.

RICHMOND, Oliver P.; TELLIDIS, Ioannis. The BRICS and international peacebuilding and statebuilding. NOREF: Norwegian peacebuilding Resource Center, January, 2013. Disponível em: http://www.peacebuilding.no/var/ezflow_site/storage/original/application/5f8c6a3d43ec8ff f5692d7b596af2491.pdf. Acesso em: 12 de abril de 2016.

RIDRUEJO, José Antonio Pastor. Le droit international à la veille du vingt et unième siècle: normes, faits et valeurs. Haia: Cours general de droit international public, 1998.

ROSAS, Maria Cristina. A reforma das Organização das Nações Unidas. In: Governança global. Rio de Janeiro: Fundação Konrad Adenauer, 2009, pp.21-38.

ROUSSEAU, Jean-Jacques. Extrato e julgamento do projeto de paz perpétua de Abbé de Saint-Pierre. In: Rousseau e as relações internacionais. São Paulo: Imprensa Oficial do Estado, Editora UNB, 2003.

RUGGIE, John G. Doctrinal unilateralism and its limits. America and global governance in the new century. Corporate social responsability iniative working paper n. 16, Havard University, 2006.

RUGGIE, John G. Multilateralism: The anatomy of an institution. International Organization 46, 3, Summer, 1992,

SAINT-PIERRE, Abbé de. Projeto para tornar perpétua a paz na europa. Brasília: Editora Universidade de Brasília, Instituto de Pesquisa de Relações Internacionais, 2003.

SAMIR, Saran. The next ten years of BRICS: will the relationship last? India Economic Summit, World Economic Forum, 2017. Disponível em: https://www.weforum.org/agenda/2017/10/brics-first-next-tenyears/?utm_content=bufferead2a\&utm_medium=social\&utm_source=facebook.com\&utm _campaign=buffer. Acesso em 27 de outubro de 2017

SANDSCHNEIDER, Eberhard. Como tratar um dragão: sobre o trato do ocidente com o complicado parceiro chinês. Rio de Janeiro: Fundação Konrad Adenauer, cadernos Adenauer, v. II, n. 1, China por toda parte, abril 2006. 
SANTOS, Boaventura de Sousa. Reconhecer para libertar. Os caminhos do cosmopolitismo multicultural. Rio de Janeiro: Civilização Brasileira, 2003.

SARDENBERG, Ronaldo Mota. Reforma das Nações Unidas: impasses, progressos e perspectivas. In: Reforma da ONU. IV Conferência Nacional de Política Externa e Política Internacional: o Brasil no mundo que vem aí. Seminário sobre a Reforma da ONU. Brasília: FUNAG, 2010, pp. 43-62.

SCHWELLER, Randall. Emerging powers in an age of disorder. Global Governance, v. 17, n. 3, jul./set. 2011, pp. 285-298.

SERPA SOARES, Miguel. Room for Growth: The contribution of international law to development. Chinese Journal of International Law, 2015.

SHAW, Malcolm N. International law. Cambridge: Cambridge University press, 2008.

SIEREN, Frank. Regime de concubinato: o que a ascensão da China significa para um país como a Alemanha. Rio de Janeiro: Fundação Konrad Adenauer, cadernos Adenauer, v. II, n. 1, China por toda parte, abril 2006.

SIYAR, Shaybain's. The islamic law of nations. Baltimore: The Johns Hopkins press, 1966.

SKRZYPCZYNSKA, Joanna. BRICS' stance in WTO. Evolutions global trends and regional issues, v. 3, n. 1, 2015, pp. 46-62.

SLAUGHTER, Anne-Marie; TULUMELLO, Andrew S.; WOOD, Stepan. International law and international relations theory: a new generation of interdisciplinary scholarship. American Journal of International Law, v. 92, 1998, pp. 367-393.

; HALE, Thomas. Transgovernmental networks and emerging powers. In: Rising states, rising institutions: challenges for global governance. Alan S. Alexandroff and Andrew F. Cooper, editors. Baltimore: Brookings Institution Press, 2010, pp. 48-62.

Security, solidarity, and sovereignty: the Grand themes of UN reform. The American Journal of International Law, v. 99, n. 3, Jul., 2005, pp. 619-631.

SMITH, Gordon S. G7 to G8 to G20: evolution in global governance. CIGI G20 Papers $/ n^{\circ}$. 6, May 2011. Disponível em: https://www.cigionline.org/sites/default/files/g20no6-2.pdf. Acesso em 24 de abril de 2015.

SOARES, João Clemente Baena. As Nações Unidas diante das ameaças, dos desafios, das mudanças. Dossiê, Centro Brasileiro de Relações Internacionais, vol. 1, Ano 4, 2005.

SOKO, Mills. A África do Sul e as ameaças tradicionais e não-tradicionais à segurança regional. In: A África do Sul e o IBAS. Desafios da Segurança Humana. Porto Alegre: Ed. da UFRGS; FUNAG, 2007.

SOTERO, Paulo. Introduction. In: Emerging powers: India, Brazil and South Africa (IBSA) and the future of south-south cooperation. Woodrow Wilson International Center for Scholars, Special Report, Aug. 2009.

SPENCE, Jonathan D. The search for modern China. New York: W. W. Norton, 1999. 
SUR, Serge. Securité colletive et rétablissement de la paix: la résolution 687 (3 Avril 1991) dans l'affaire du Golfe. In: Le développment du rôle du Conseil de Securité. Peacekeeping and Peace-Building. Préparé par René-Jean DUPUY. Colloque, La Haye 21-23 Julliet,1992. London: Martinus Nijhoff Publishers, 1993, pp. 13-39.

; COMBACAU, Jean. Droit international public. $6^{\circ}$ ed. Paris: Montchrestien, 2004.

STIGLITZ, Joseph; STERN, Nicholas; ROMANI, Mattia; BHATTACHARYA, Amar. A new world's New Development Bank. Project-Syndicate, 2013. Disponível em: https://www.project-syndicate.org/commentary/the-benefits-of-the-brics-developmentbank?barrier=accessreg. Acesso em 22 de Agosto de 2015.

SWEDBERG, Richard. The doctrine of economic neutrality of IMF and World Bank. Journal of peace research, v. 23. n. 4, 1986.

TAMMEN, Rnald L.; KUGLER, Jacek; LEMKE, Douglas. Power transition theory. Transresearch consortium work paper, n.1, 2011.

TARAZI, Salah El Dine. Voto da decisão da Corte Internacional de Justiça sobre o pessoal diplomático e consular dos Estados Unidos em Teerã. Disponível em: http://www.icjcij.org/docket/index.php?p1=3\&p2=3\&code=usir\&case $=64 \& k=c 9 \& p 3=0 \& 1$ ang=fr. Acesso em 26 de agosto de 2014.

TARRAGÔ, Piragibe dos S. A Reforma da ONU: A Comissão de Construção da Paz e ampliação do Conselho de Segurança. In: Reforma da ONU. IV Conferência Nacional de Política Externa e Política Internacional: o Brasil no mundo que vem aí. Seminário sobre a Reforma da ONU. Brasília: FUNAG, 2010, pp. 27-42.

TERZ, Panos; BUELVAS, Eduardo Pastrana. El derecho internacional al despuntar el siglo XXI, un punto de vista sociológico del derecho internacional. ad defensionem iuris inter gentes. Colômbia: Pontifícia Universidad Javeriana, Papel Político, v. 12, n.2, jul/dez, 2007, pp. 535-564.

THORSTENSEN, Vera et. al. Os BRICS na OMC: políticas comerciais comparadas de Brasil, Rússia, Índia, China e África do Sul. Brasília: IPEA, 2012.

TOYE, John; TOYE, Richard. The UN and global political economy. Trade, finance and development. Bloomington: Indiana University Press, 2004.

TRINDADE, Antônio Augusto Cançado. Los aportes latinoamericanos al derecho y a la justicia internacionales. Ciudad de Mexico: Acervo de la Biblioteca Jurídica Virtual del Instituto de Investigaciones Jurídicas de la UNAM, 2002.

Desafios e conquistas do direito internacional dos direitos humanos no início do século XXI. Trabalho de pesquisa apresentado pelo Autor em forma de três conferências proferidas pelo Autor no XXXIII Curso de Direito Internacional Organizado pela Comissão Jurídica Interamericana da OEA, no Rio de Janeiro, em 18 e 21-22 de agosto de 2006. Disponível em: http://www.oas.org/dil/esp/407490\%20 cancado\%20trindade\%20OEA\%20CJI\%20\%20.def.pdf. Acesso em 03 de setembro de 2014.

Direito das organizações internacionais, $3^{\mathrm{a}}$ ed. Belo Horizonte: Del Rey, 2003. 
As Nações Unidas e a Nova Ordem Econômica Internacional. Revista Informativa do Legislativo n. 81, jan.mar., 1984.

TROSZCZYŃSKA-VAN GENDEREN, Vanda. Reforming the United Nations: State of Play, Ways Forward. Bruxelas: European Union, study, directorate-general for external policies policy department, march, 2015. Disponível em: http://www.europarl.europa.eu/RegData/etudes/STUD/2015/536435/EXPO_STU(2015)53 6435_EN.pdf. Acesso em 16 de dezembro de 2016.

UZIEL, Eduardo; OLIVEIRA, Ana Paula; ROCHA, Rafael. A atuação dos BRICS no Conselho de Segurança das Nações Unidas no ano de 2011. Revista Política Externa, v. $23, n^{\circ} 4,2015$.

VATTEL, Emer de. Le droit des gens ou principes de la loi naturelle, appliqués à la conduite et aux affaires des nations et des souverains, Washington: Carnegie Institution of Washington, v. I e II, 1916.

VELASCO, Manuel Diez. Instituciones de derecho internacional público. $16^{\mathrm{a}}$ edição. Madrid: Tecnos, 2007.

VESTERGAARD, Jakob. The World Bank and the emerging world order: Adjusting to multipolarity at the second decimal point. DIIS report 2011. Copenhagen: Danish Institute for International Studies, 2011.

; WADE, Robert H. Protecting power: how western states retain the dominant voice in the world bank's governance. World Development, v. 46, 2013, pp. 153-164.

VIRALLY, Michel. Le droit international en devenir. Essais écrits au fil des ans. Genève : Graduate Institute Publications, 1990.

VISENTINI, Paulo et al. BRICS: as potências emergentes. Petrópolis, Rio de Janeiro: Editora Vozes, 2013.

ZAMORA, Stephen. Voting in international economic organization. The American Journal of International Law, v. 74, n. 3, jul., 1980, pp. 566-608.

ZÜRN, Michael. Global governance and legitimacy problems. Government and opposition, v. 39, n. 2, 2004, pp. 260-287.

WADE, Robert H. Emerging world order? From multipolarity to multilateralism in the G20, the World Bank, and the IMF. SAGE Publications, Politics and Society, 39, 3, 2011, pp. 347-378.

WÆVER, Ole. The sociology of a not so international discipline: american and european developments in international relations. International Organization. v. 52 n. 4. Outono, 1998, pp. 687-727.

WANG, Hongying. New multilateral development banks: opportunities and challenges for global governance. New York: Council on Foreign Relations, 2016.

WEILER, Joseph H. The geology of international law. Governance, democracy and legitimacy. Heidelberg Journal of International Law, n. 64, 2004, pp.547-562. 
WEISS, Edith Brown. International Law in a Kaleidoscopic World. Asian Journal of International Law, v. 1, Issue 1, 2011, pp. 21-32.

WENDT, Alexander. Social theory of international politics. Cambridge: Cambridge University Press, 1999.

WINKELMANN, Ingo. Bringing the Security Council into a new era: recent developments in the discussion on the reform of the Security Council. Max Planck Yearbook of United Nations Law. New York: United Nations, 1997.

WOLFRUM, Rügider. Legitimacy of international law from a legal perspective: some introductory considerations. In: Legitimacy in international law. Berlin: Springer, 2008, pp. 1-8.

WOOD, Bernard. Middle powers in the international system: a preliminary assessment of potencial. Wider working papers, United Nations University, 1987.

WOOD, Christopher et. al. The New Development Bank: moving the BRICS from an acronym to an institution. The South African Institute of International Affairs (SAIIA), African perspectives, global insights, 2016.

WOODS, Ngaire et. al. Transforming global governance for the 21st century. New York: UNDP Human Development Report Office, occasional paper, 2013.

. Governing the global economy: Strengthening multilateral institutions. International Peace Institute, 2008.

The challenge of good governance for the IMF and the World Bank themselves. World Development, v. 28, n. 5, 200, pp. 823-841.

. The United States and the international financial institutions: power and influence within the World Bank and the IMF. In: US hegemony and international organizations. The United States and multilateral institutions. New York: Oxford University Press, 2003, pp.92-114.

WOUTERS, Jan; RUYS, Tom. Security Council Reform: a new veto for a new century? Brussels: Royal Institute for International Relations (irri-kiib), August, 2005.

; MEESTER, Bart De; RYNGAERT, Cedric. Democracy and international law. Leuven: LIRGIAD, working paper n. 5, 2004.

WRIGHT, Christopher. O Banco Mundial em um mundo em mutação. In: Governança global. Rio de Janeiro: Fundação Konrad Adenauer, 2009.

YING, Huang. BRICS: a new cooperation model in horizon. In: Laying the BRICS of a New Global Order: From Yekaterinburg 2009 to eThekwini 2013. Editors Francis A. Kornegay and Narnia Bohler-Muller. Pretória: Africa Institute of South Africa, 2013, pp. 51- 64.

ZHAO, Huanyu. Evolution of the BRICS institutionalization: challenges and opportunities for the EU Strategic Partnership with the BRICS. Brussels: UACES, Paper for UACES Student Forum Conference, 2016. 
Notícias e Documentos:

BIMSTEC, The Bay of Bengal Initiative for Multi-Sectoral Technical and Economic Cooperation. Background. Disponível em:

http://www.bimstec.org/index.php?page=overview. Acesso em 02 de novembro de 2016.

BRASIL, Banco Nacional de Desenvolvimento Econômico e Social. BNDES fecha contrato de US\$ 300 milhões com o Novo Banco de Desenvolvimento para financiar energia renovável alternativa. Disponível em: www.bndes.gov.br. Acesso em: 26 de abril de 2017.

BRASIL, Governo do Brasil. Empresários dos Brics e Ibas discutem aumento do comércio e crescimento sustentável. Disponível em:

http://www.brasil.gov.br/governo/2010/04/empresarios-dos-brics-e-ibas-discutemaumento-do-comercio-e-crescimento-sustentavel. Acesso em: 14 de novembro de 2015.

BRASIL, Ministério das Relações Exteriores. Declaração de Brasília. Disponível em http://www.itamaraty.gov.br/temas-maisinformacoes/temas-mais-informacoes/saiba-maisibas/documentos-emitidos-pelos-chefes-deestado-e-de/declaracao-de-brasilia/view. Acesso em: 12 de novembro de 2014.

BRASIL, Ministério das Relações Exteriores. 2a Cúpula do IBAS, 2007. Disponível em: http://www.itamaraty.gov.br/temas-mais-informaçoes/saiba-mais-ibas/documentos. Acesso em: 12 de novembro de 2014.

BRASIL, Ministério das Relações Exteriores. $1^{\circ}$ Cúpula dos BRICS - Declaração Conjunta, 2009. Disponível em: http://brics.itamaraty.gov.br/pt_br/categoria-portugues/20documentos/73-primeiro-declaracao. Acesso em: 03 de março de 2015.

BRASIL, Ministério das Relações Exteriores. Nota 145, III Cúpula dos BRICS.

Disponível em:

http://www.itamaraty.gov.br/index.php?option=com_content \&view=article \&id=2559:iiicupula-do-brics-sanya-14-de-abril-de-2011\&catid=42\&Itemid=280\&lang=pt-BR. Acesso em: 4 de fevereiro de 2016.

BRASIL, Ministério das Relações Exteriores. Declaração de eThekwini, V Cúpula dos BRICS, 2013. Disponível em:http://brics.itamaraty.gov.br/pt_br/categoria-portugues/20documentos/77-quinta-declaracao-conjunta. Acesso em: 12 de janeiro de 2016.

BRASIL, Ministério das Relações Exteriores. Informações sobre os BRICS. Disponível em: http://brics.itamaraty.gov.br/pt_br/sobre-o-brics/informacao-sobre-o-brics. Acesso em: 15 de outubro de 2015.

BRASIL, Ministério das Relações Exteriores do. Reforma do Conselho de Segurança das Nações Unidas. Disponível em: http://csnu.itamaraty.gov.br/glossario. Acesso em 30 de setembro de 2016.

BRASIL, Ministério das Relações Exteriores. Diplomacia empresarial e financeira:

Fundo Monetário Internacional. Disponível em: http://www.itamaraty.gov.br/pt-

$\mathrm{BR} /$ politica-externa/diplomacia-economica-comercial-e-financeira/119-fundo-monetariointernacional. Acesso em 18 de março de 2017. 
BRASIL, Ministério das Relações Exteriores. Declaração de Ufá, VII Cúpula dos BRICS. Disponível

em:http://www.itamaraty.gov.br/index.php?option=com_content $\&$ view=article $\&$ id=10465: vii-cupula-do-brics-declaracao-de-ufa-ufa-russia-9-de-julho-de-2015\&catid=42\&lang=ptBR\&Itemid=280. Acesso em 26 de janeiro de 2016.

BRASIL, Ministério das Relações Exteriores. BRICS, Joint Statistical Publications, 2012. Disponível em: http://brics.itamaraty.gov.br/joint-statistical-publications. Acesso em 12 de janeiro de 2016.

BRASIL, Ministério das Relações Exteriores. Banco Mundial. Disponível em: http://www.itamaraty.gov.br/pt-BR/politica-externa/diplomacia-economica-comercial-efinanceira/120-banco-mundial. Acesso em 5 de abril de 2017.

BRASIL, Ministério das Relações Exteriores. Goa Declaration. Disponível em: http://www.itamaraty.gov.br/pt-BR/notas-a-imprensa/14931-viii-cupula-do-brics-goaindia-15-e-16-de-outubro-de-2016-declaracao-e-plano-de-acao-de-goa. Acesso em: 22 de outubro de 2016.

BRASIL, Ministério das Relações Exteriores. Memorandum of understanding for establishment of BRICS agricultural research platform. Disponível em: http://www.itamaraty.gov.br/pt-BR/notas-a-imprensa/14933-viii-cupula-do-brics-goaindia-15-e-16-de-outubro-de-2016-atos-assinados\#1reg. Acesso: em 22 de dezembro de 2016.

BRASIL, Ministério das Relações Exteriores do Brasil. Memorandum of understanding on mutual cooperation between the Rio Branco Institute of the Ministry of Foreign Affairs of The Federative Republic of Brazil, the Diplomatic Academy of the Ministry of Foreign Affairs of The Russian Federation, the Foreign Service Institute of Ministry of External Affairs of The Republic Of India, the China Foreign Affairs University And The China Diplomatic Academy of The Ministry Of Foreign Affairs of The People's Republic of China And The Diplomatic Academy of The Department of International Relations and Cooperation of The Republic of South Africa. Disponível em:

http://www.itamaraty.gov.br/pt-BR/notas-a-imprensa/14933-viii-cupula-do-brics-goaindia-15-e-16-de-outubro-de-2016-atos-assinados\#2memo. Acesso: em 22 de dezembro de 2016.

BRASIL, Ministério das Relações Exteriores. Regulation on the customs cooperation committee of the Brics. Disponível em: http://www.itamaraty.gov.br/pt-BR/notas-aimprensa/14933-viii-cupula-do-brics-goa-india-15-e-16-de-outubro-de-2016-atosassinados\#1reg. Acesso: em 22 de dezembro de 2016.

BRASIL, Ministério das Relações Exteriores. Adoção pelo Conselho de Segurança das Nações Unidas da Resolução 2254 sobre a Síria. Disponível em: http://www.itamaraty.gov.br/pt-BR/notas-a-imprensa/12790-adocao-pelo-conselho-deseguranca-das-nacoes-unidas-da-resolucao-2254-sobre-a-siria. Acesso em: 13 de abril de 2017.

BRASIL, Ministério das Relações Exteriores. BASIC. Disponível em: http://www.brasil.gov.br/meio-ambiente/2011/11/entenda-o-basic. Acesso: em 17 de maio de 2017. 
BRASIL, Ministério das Relações Exteriores. Reunião de Ministros do BASIC sobre Mudança do Clima. Disponível em: http://www.itamaraty.gov.br/pt-

$\mathrm{BR} /$ component/tags/tag/516-grupo-de-paises-basic-brasil-africa-do-sul-india-e-china. Acesso em: 17 de maio de 2017.

BRASIL, Ministério das Relações Exteriores. Reforma das instituições financeiras internacionais. Disponível em: http://www.itamaraty.gov.br/pt-BR/politicaexterna/diplomacia-economica-comercial-e-financeira/15553-reforma-das-instituicoesfinanceiras-internacionais. Acesso em: 22 de maio de 2017.

BRASIL, Ministério das Relações Exteriores. Declaração dos Ministros de Comércio do BRICS - Genebra, 14 de dezembro de 2011. Disponível em: http://www.itamaraty.gov.br/pt-BR/notas-a-imprensa/2907-declaracao-dos-ministros-decomercio-do-brics-genebra-14-de-dezembro-de-2011. Acesso em: 16 de dezembro de 2016.

BRASIL, Ministério das Relações Exteriores. Declaração Conjunta da $4^{\text {a }}$ Reunião de Ministros da Agricultura e do Desenvolvimento Agrário do BRICS - Brasília, 13 de março de 2015. Disponível em: http://www.itamaraty.gov.br/pt-BR/notas-aimprensa/8317-declaracao-conjunta-da-4-reuniao-de-ministros-da-agricultura-e-dodesenvolvimento-agrario-do-brics-brasilia-13-de-marco-de-2015. Acesso em: 31 de maio de 2017.

BRASIL, Ministério das Relações Exteriores. Memorando de entendimento para o estabelecimento da Rede de Universidade dos BRICS. Disponível em:

http://brics.itamaraty.gov.br/images/comunicados/memorandoredeunivbrics.pdf. Acesso em: Acesso em: 20 de dezembro de 2016.

BRASIL, Ministério das Relações Exteriores. O Brasil no G-20. Disponível em: http://www.itamaraty.gov.br/pt-BR/politica-externa/diplomacia-economica-comercial-efinanceira/118-g20. Acesso em: 04 de junho de 2017.

BRASIL, Ministério das Relações Exteriores. Comunicado dos líderes do G20 - Cúpula de Hangzhou - 4-5 de setembro de 2016. Disponível em: http://www.itamaraty.gov.br/ptBR/notas-a-imprensa/14700-comunicado-dos-lideres-do-g20-cupula-de-hangzhou-4-5-desetembro-de-2016. Acesso em: 04 de junho de 2017.

BRASIL, Ministério das Relações Exteriores. Declaração de Xiamen. Disponível em: http://www.itamaraty.gov.br/pt-BR/notas-a-imprensa/17384-nona-cupula-do-bricsdeclaracao-de-xiamen-xiamen-china-4-de-setembro-de-2017. Acesso em: 10 de setembro de 2017.

BRASIL, Ministério das Relações Exteriores. Aprovação da estratégia geral do Novo Banco de Desenvolvimento para o período 2017-202. Disponível em: http://www.itamaraty.gov.br/pt-BR/ficha-pais/16755-aprovacao-da-estrategia-geral-donovo-banco-de-desenvolvimento-para-o-periodo-2017-2021. Acesso em 20 de setembro de 2017.

BRASIL, Ministério das Relações Exteriores. Principais áreas e temas de diálogo entre os BRICS. Disponível em: http://brics.itamaraty.gov.br/pt_br/sobre-o-brics/principaisareas-e-temas-de-dialogo-entre-os-brics. Acesso em: 22 de janeiro de 2016. 
BRASIL, Ministério das Relações Exteriores. Declaração de Tshwane, IBAS, 2011. Disponível em: http://www.itamaraty.gov.br/pt-BR/notas-a-imprensa/2816-v-cupula-doforum-de-dialogo-india-brasil-e-africa-do-sul-ibas-declaracao-de-tshwane-18-10-2011. Acesso em: 07 de janeiro de 2016.

BRASIL, Ministério da Indústria, Comércio Exterior e Serviços. Integrantes dos Brics buscam maior coordenação das políticas comerciais. Disponível em:

http://www.mdic.gov.br/component/content/article?id=1983. Acesso em: 29 de outubro de 2016.

BRASIL, Ministério da Ciência, Tecnologia, Inovações e Telecomunicações. Memorando de entendimento sobre a cooperação em ciência, tecnologia e inovação entre os governos da República Federativa do Brasil, Federação da Rússia, República da Índia, República Popular da China e República da África do Sul. Disponível em: http://www.mcti.gov.br/documents/10179/35540/Memorando+CT\%26I+Brics++2015.pdf. Acesso em: 20 de dezembro de 2016.

BRASIL, Ministério da Ciência, Tecnologia, Inovações e Telecomunicações. Países dos Brics querem compartilhar dados de satélites de sensoriamento remoto. Disponível em: http://www.mctic.gov.br/mctic/opencms/salaImprensa/noticias/arquivos/2017/09/Paises_d os_Brics_querem_compartilhar_dados_de_satelites_de_sensoriamento_remoto.html. Acesso em: 20 de outubro de 2017.

BRASIL. Decreto $\mathrm{n}^{\circ} 8.702$ de 01 de abril de 2016. Promulga o Tratado para o Estabelecimento do Arranjo Contingente de Reservas dos BRICS. Disponível em: http://www.planalto.gov.br/ccivil_03/_ato2015-2018/2016/decreto/D8702.htm. Acesso em: 06 de janeiro de 2017.

BRASIL, Presidência da República. Conselho Nacional de Segurança Alimentar e Nutricional. Plataforma de pesquisa ampliará cooperação em agricultura e segurança alimentar no BRICS. Disponível em: http://www4.planalto.gov.br/consea/comunicacao/noticias/2016/brics-vao-criarplataforma-de-pesquisa-para-ampliar-cooperacao-em-agricultura-e-seguranca-alimentar. Acesso: em 02 de novembro de 2016.

BRICS 2017 China. BRICS Action Plan for Innovation Cooperation (2017-2020). Disponível em:

https://brics2017.org/English/Headlines/201708/P020170825384436195685.pdf. Acesso em: 15 de outubro de 2017.

CHINA, Ministry of Foreign Affairs of the People's Republic of. Position paper of the People's Republic of China on the United Nations Reforms. Chinese Journal of International Law (2005), v. 4, n. 2, 685-698.

CONECTAS direitos humanos. Banco dos Brics. Reunião da sociedade civil discutiu desafios para a agenda socioambiental do Novo Banco de Desenvolvimento dos Brics. Disponível em: http://www.conectas.org/pt/acoes/empresas-e-direitoshumanos/noticia/43612-banco-dos-brics. Acesso em 24 de maio de 2017. 
INDIA, Ministry of External Affairs. Question No.3570 Key Initiatives of BRICS. http://www.mea.gov.in/loksabha.htm?dtl/27769/question+no3570+key+initiatives+of+brics. Acesso em: 07 de dezembro de 2016.

INDIA, Ministry of External Affairs. Goa Declaration. Disponível em: http://mea.gov.in/bilateraldocuments.htm?dtl/27491/Goa+Declaration+at+8th+BRICS+Summit. Acesso em: 22 de outubro de 2016.

INSTITUTE DE DROIT INTERNATIONAL. Judicial control of Security Council decisions (UNO) Rapporteur: Rüdiger Wolfrum. Yearbook of Institute of International Law - Tallinn Session - Volume 76, 2015.

INTERNATIONAL Monetary Fund. Quota and voting shares before and after implementation of reforms agreed in 2008 and 2010. Disponível em: http://www.imf.org/external/np/sec/pr/2011/pdfs/quota_tbl.pdf. Acesso em: 4 de março de 2016.

INTERNATIONAL Monetary Fund. History. Disponível em: https://www.imf.org/external/about/histcoop.htm. Acesso em: 10 de janeiro de 2016.

INTERNATIONAL Monetary Fund. Statuts du fonds monétaire international.

Disponível em: https://www.imf.org/external/french/pubs/ft/aa/aa.pdf. Acesso em: 18 de março de 2017.

INTERNATIONAL Monetary Fund. Quotes-parts au FMI. Disponível em: https://www.imf.org/external/np/exr/facts/fre/quotasf.htm. Acesso em: 25 de março de 2017.

INTERNATIONAL Monetary Fund. Comunicado de Prensa: El Directorio Ejecutivo del FMI aprueba una importante revisión de las cuotas y la estructura de gobierno.

Disponível em: http://www.imf.org/es/News/Articles/2015/09/14/01/49/pr10418. Acesso em: 04 de fevereiro de 2017.

INTERNATIONAL Monetary Fund. Report of the Executive Board to the Board of Governors quota and voice reform in the International Monetary Fund August 31, 2006. Disponível em: https://www.imf.org/external/np/pp/eng/2006/083106.pdf. Acesso em: 25 de março de 2017.

INTERNATIONAL Monetary Fund. Reforma de las cuotas y la representación en el FMI: Responder a los cambios de la economía mundial. Estudios temáticos, n. 2, 2007. Disponível em: https://www.imf.org/external/np/exr/ib/2007/es1/041307s.pdf. Acesso em: 26 de março de 2017.

INTERNATIONAL Monetary Fund. IMF members' quotas and voting power, and IMF Board of Governors. Disponível em: http://www.imf.org/external/np/sec/memdir/members.aspx. Acesso em 10 de janeiro de 2017. 
NAÇÕES UNIDAS, Carta das Nações Unidas, Decreto n ${ }^{\circ}$ 19.841/45. Disponível em: http://www.planalto.gov.br/ccivil_03/decreto/1930-1949/d19841.htm. Acesso em 19 de setembro de 2016.

NAÇÕES UNIDAS do BRASIL. OIT elogia compromisso dos BRICS de impulsionar crescimento e trabalho decente. Disponível em: https://nacoesunidas.org/oit-elogiacompromisso-dos-brics-de-impulsionar-crescimento-e-trabalho-decente/. Acesso em: 24 de maio de 2017.

NEW DEVELOPMENT BANK. NDB president: $\mathbf{6 0 \%}$ of funding will be for renewables. Disponível em: http://www.ndb.int/president_desk/ndb-president-60-funding-willrenewables/. Acesso em: 24 de abril de 2017.

NEW DEVELOPMENT BANK. Environment and Social Framework, 2016. Disponível em: http://www.ndb.int/wp-content/uploads/2017/02/ndb-environment-social-framework20160330.pdf. Acesso em: 25 de abril de 2017.

NEW DEVELOPMENT BANK. Projects. Disponível em: http://www.ndb.int/projects/list-of-all-projects/. Acesso em: 25 de abril de 2017.

NEW DEVELOPMENT BANK. List of memoranda of understanding and cooperation agreements. Disponível em: http://www.ndb.int/partnerships/list-of-partnerships/. Acesso em: 02 de maio de 2017.

NEW DEVELOPMENT BANK. Environment and Social Sustainability. Disponível em: http://www.ndb.int/about-us/strategy/environmental-social-sustainability/. Acesso em: $1^{\circ}$ de maio de 2017.

NEW DEVELOPMENT BANK. Partnerships. Disponível em: http://www.ndb.int/partnerships/civil-academic-societies/. Acesso em: 22 de abril de 2017.

NEW DEVELOPMENT BANK. Meeting with representatives of civil society organizations on the sidelines of NDB second annual meeting. Disponível em: http://www.ndb.int/press_release/meeting-representatives-civil-society-organizationssidelines-ndb-second-annual-meeting/. Aceso em: 04 de maio de 2017.

NEW DEVELOPMENT BANK, NDB's General Strategy: 2017 - 2021. Disponível em: http://www.ndb.int/wp-content/uploads/2017/07/NDB-Strategy-Final.pdf. Acesso em: 20 de setembro de 2017.

NEW DEVELOPMENT BANK. NDB signs \$800m loan deals with china for three green projects. Disponível em: https://www.ndb.int/media/ndb-signs-800m-loan-dealschina-three-green-projects/. Acesso em: 18 de novembro de 2017.

ORGANIZAÇÃO PARA A COOPERAÇÃO ISLÂMICA.OCI, UN Security Council meeting on strengthening partnership with OIC, Ihsanoglu stresses OIC's commitment to active partnership and the need for UNSC reform. Disponível em: http://www.oicun.org/9/20131031053410293.html. Acesso em: 6 de janeiro de 2017.

OXFAM BRASIL. Sociedade civil e o Novo Banco de Desenvolvimento: aonde estamos e para onde vamos? Documento de apoio para a oficina "novo banco de desenvolvimento e sociedade civil brasileira: articulando estratégias para incidência", agosto de 2017.

Disponível 
em:https://www.oxfam.org.br/sites/default/files/publicacoes/sociedade_civil_e_o_novo_ba nco_de_desenvolvimento.pdf. Acesso em: 18 de outubro de 2017.

PNUD, Relatório de Desenvolvimento Humano 2013. A ascensão do Sul: progresso humano num mundo diversificado. Disponível em:

http://hdr.undp.org/sites/default/files/hdr2013_portuguese.pdf. Acesso em: 26 de outubro de 2017.

RUSSIA FEDERATION. The Ministry of Foreign Affairs of the. БРИКС. Joint Communiqué on the Meeting of BRICS Special Envoys on Middle East, Visakhapatnam, April 12, 2017. Disponível em: http://www.mid.ru/en/web/guest/briks//asset_publisher/RdlYjVvdPAwg/content/id/2725737. Acesso em: 13 de abril de 2017.

RUSSIAN FEDERATION, Ministry of Economic Development. BRICS action agenda on economic and trade cooperation". Disponível em:

http://economy.gov.ru/wps/wcm/connect/88d87c66-ec8e-4398-ae01-

c1dfad7423a8/2017040910.pdf?MOD=AJPERES\&CACHEID=88d87c66-ec8e-4398ae01-c1dfad7423a8. Acesso em: 15 de outubro de 2017.

UNITED NATIONS. Rules of procedure of the General Assembly. New York, 2008. Disponível em:

http://www.un.org/depts/DGACM/Uploaded $\% 20$ docs/rules $\% 20$ of $\% 20$ procedure $\% 20 \mathrm{of} \% 2$ 0ga.pdf. Acesso em: 19 de setembro de 2016.

UNITED NATIONS. Ranking of military and police contributions to UM operations. Disponível em: http://www.un.org/en/peacekeeping/contributors/2016/feb16_2.pdf.

Acesso em: 18 de outubro de 2016.

UNITED NATIONS. 1944-1945: Conférences de Dumbartom Oaks et de Yalta.

Disponível em: http://www.un.org/fr/sections/history-united-nations-charter/1944-1945dumbarton-oaks-and-yalta/index.html. Acesso em: 22 de novembro de 2016.

UNITED NATIONS. More secure world: our shared responsibility. Report of the High-Level Panel on Threats, Challenges and Change, UN Doc. A/59/565, 8, 2004.

Disponível em:http://www.un.org/en/peacebuilding/pdf/historical/hlp_more_secure_world.pdf. Acesso em: 06 de janeiro de 2017.

UNITED NATIONS. Report of the Ccommission of experts of the President of the United Nations General Assembly on reforms of the International Monetary and Financial System. New York, 21 September 2009. Disponível em:

http://www.un.org/ga/econcrisissummit/docs/FinalReport_CoE.pdf. Acesso em: 10 de agosto de 2017

UNITED NATIONS press. Secretary-general presents report 'in larger freedom' to general assembly, outlining ambitious plan for United Nations reform. 21 march 2005. Disponível em: http://www.un.org/press/en/2005/ga10334.doc.htm. Acesso: em 31 de março de 2017.

UNITED NATIONS, General Assembly. Open-ended working group on the question of equitable representation on and increase in the membership of the security council and other matters related to the security council. Official Records. Fifty-first session. 
Supplement no 47 (A/51/47), New York, 1997. Disponível em: http://www.unilibrary.org/united-nations/report-of-the-open-ended-working-group-on-the-question-ofequitable-representation-on-and-increase-in-the-membership-of-the-security-council-andother-matters-related-to-the-security-council_7d2308cf-en. Acesso em: 9 de outubro de 2016.

UNITED NATIONS, General Assembly. Resolution adopted by the General Assembly 3201 (S-VI). Declaration on the Establishment of a New International Economic Order. Disponível em: http://www.un-documents.net/s6r3201.htm. Acesso em: 18 de março de 2017.

UNITED NATIONS, General Assembly. Resolution adopted by the General Assembly on 19 December 2006, A/RES/61/160. Promotion of a democratic and equitable international order. Disponível em:

http://www.un.org/en/ga/search/view_doc.asp?symbol=A/RES/61/160\&referer=http://ww w.un.org/depts/dhl/resguide/r61_resolutions_table_eng.htm\&Lang=E. Acesso em: 07 de setembro de 2017.

UNITED NATIONS, General Assembly. Resolution adopted by the General Assembly on 9 July 2009 A/RES/63/303. Disponível em:

http://www.un.org/ga/search/view_doc.asp?symbol=A/RES/63/303\&referer=http://www.u n.org/ga/econcrisissummit/\&Lang=E. Acesso em: 10 de agosto de 2017.

UNITED NATIONS, General Assembly. Fifty-ninth session Agenda item 53 Question of equitable representation on and increase in the membership of the Security Council and related matters (A/59/L.68). Disponível em: https://documents-dds-

ny.un.org/doc/UNDOC/LTD/N05/434/76/PDF/N0543476.pdf?OpenElement. Acesso em: 28 de setembro de 2016.

UNITED NATIONS, Security Council. Disponível em: http://www.un.org/en/sc/about/. Acesso em: 19 de setembro de 2016.

UNITED NATIONS, Security Council. Agenda de situation in Libya. 6498 meeting, NY,17 march 2011. Disponível em:

http://www.un.org/en/ga/search/view_doc.asp?symbol=S/PV.6498. Acesso em: $18 \mathrm{de}$ outubro de 2016.

UNITED NATIONS, Security Council. Countries elected members of the Security

Council. Disponível em: http://www.un.org/en/sc/members/elected.asp. Acesso em: 18 de outubro de 2016.

UNITED NATIONS INDUSTRIAL DEVELOPMENT ORGANIZATION. UNIDOBRICS cooperation quarterly report. Disponível em:

https://www.unido.org/fileadmin/user_media_upgrade/What_we_do/Topics/BRICS_coope ration/UNIDO_BRICS_Report_27.2.2017.pdf. Acesso em: 20 de maio de 2017.

UNITED NATIONS treaty collection. International Convention for the Suppression of the Financing of Terrorism. Disponível em:

https://treaties.un.org/pages/ViewDetails.aspx?src=TREATY\&mtdsg_no=XVIII-

$11 \&$ chapter=18\&clang=_en. Acesso em: 30 de maio de 2017. 
UNITED NATIONS treaty collection. The Arms Trade Treaty. Disponível em: https://www.un.org/disarmament/convarms/att/. Acesso em: 30 de maio de 2017.

UNITED NATIONS Office for Disarmament Affairs (UNODA). Disarmament treaties database. Disponível em: http://disarmament.un.org/treaties/. Acesso em: 15 de maio de 2017.

WORLD BANK. O Banco Mundial reforma o direito de voto. Disponível em: http://www.worldbank.org/pt/news/press-release/2010/04/25/world-bank-reforms-votingpower-gets-86-billion-boost. Acesso em: 5 de abril de 2017.

WORLD BANK. Organization. Disponível em:

http://www.bancomundial.org/es/about/leadership. Acesso em: 5 de abril de 2017.

WORLD BANK. Global Development Horizons 2011 Multipolarity: The New Global Economy. Disponível em:

http://siteresources.worldbank.org/INTGDH/Resources/GDH_CompleteReport2011.pdf. Acesso em 20 de dezembro de 2016. 


\section{ANEXOS}

\section{ANEXO 1}

Entrevista com o Vice-Presidente do Novo Banco de Desenvolvimento, realizada na sede do Banco, em Xangai, julho de 2017.

Paulo Nogueira Batista Jr. é economista e mestre em história econômica pela University of London. Foi pesquisador do Centro de Estudos Monetários e de Economia Internacional da Fundação Getúlio Vargas do Rio de Janeiro. Atuou como diretor-executivo do Fundo Monetário Internacional (FMI) durante quase dez anos. Paulo Nogueira Batista Jr. também participou da agenda de cooperação dos BRICS, notadamente quanto ao trabalho preparatório para a criação do Novo Banco de Desenvolvimento (NBD) e do Arranjo Contingente de Reservas, que foram estabelecidos por acordos firmados em julho de 2014, durante a VI Reunião de Líderes em Fortaleza. Com essas credenciais, o governo brasileiro o designou, em 2015, para assumir o cargo de Vice-Presidente do Novo Banco de Desenvolvimento.

\section{Questões - Entrevista Sr. Paulo Nogueira Batista, vice-presidente do NDB}

Pergunta 1) O NDB tem o potencial de influenciar outros bancos de desenvolvimento se for capaz de impulsionar a inovação em matéria de financiamento do desenvolvimento, bem como no sentido de trazer novas abordagens. Inovação parece ser um objetivo claro do banco. Nos termos do NDB's General Strategy: 2017 - 2021, o NBD pretende ser rápido, flexível e eficiente, criando um projeto mais simplificado de supervisão de revisão e implementação sem burocracia desnecessária. O senhor considera essas inovações substanciais em relação às práticas adotadas por outros bancos multilaterais?

Resposta 1) Pergunta importante. Estamos abordando exatamente isso. Não é a única maneira que temos de influenciar, mas certamente uma delas. Os Bancos existentes, como o Banco Mundial e outros, são lentos em alguns aspectos e operam com excesso de burocracia. Embora queiram resolver isso, enfrentam dificuldades de lidar com a questão. São 
instituições antigas e que enfrentam todas as dificuldades de lidar com esses problemas. O NDB é jovem e tem condições de criar mecanismos hábeis. Constam na nossa estratégia a eficiência e a agilidade, as quais tentamos implementar na prática. Uma das vantagens é que não temos uma diretoria residente, o que gera redução de custo, menor prestação de contas e consequente redução de burocracia. Para se ter uma ideia, houve toda uma controvérsia, no início da criação das instituições de Bretton Woods, entre o Keynes e o White no que diz respeito à essa temática, com Keynes defendendo que a diretoria deveria ser não residente; enquanto White atuou na defesa de uma diretoria residente. A tese de White prevaleceu, assim como em muitas outras questões. Hoje há um certo consenso de que a diretoria residente é ruim em muitos aspectos. Cumpre salientar, entretanto, que nem todos os bancos de desenvolvimento enfrentam esses problemas relacionados à burocracia. A CAF e o FONPLATA são bons exemplos de agilidade e eficiência.

Pergunta 2) Conciliar obras de infraestrutura com sustentabilidade constituirá um dos maiores desafios do NDB que, apesar de todos os compromissos e políticas ambientais adotadas, pode encontrar barreiras, sobretudo no que diz respeito ao monitoramento das atividades desenvolvidas. Alguns membros da sociedade civil argumentam que as políticas ambientais do banco acabam por privilegiar o uso de sistemas internos dos países, sem processos ou critérios claros pelos quais tais sistemas serão avaliados. Essa lacuna é uma grande preocupação, uma vez que muitos países em desenvolvimento estão ameaçando desmantelar suas proteções socioambientais nacionais, como é o caso do Brasil com as propostas que dão fim ao licenciamento ambiental. Como o NBD lidará com essa questão?

Resposta 2) O NBD privilegia os sistemas internos em políticas ambientais e sociais. Como consta na estratégia, o Banco não aceita diretamente a prevalência do sistema nacional; há uma avaliação prévia na qual é realizada uma comparação dos requisitos estabelecidos nas políticas ambientais e sociais. É realizada uma avaliação dos sistemas antes da aprovação do projeto. Por exemplo, nas primeiras etapas de avaliação do projeto do Brasil, avaliou-se o sistema nacional através de um relatório produzido por uma equipe brasileira de consultoria. O relatório foi considerado adequado pelo Banco. Os bancos de desenvolvimento geralmente adotam dois processos para se alcançar um resultado em matéria ambiental: i) o Banco opta por adotar os sistemas nacionais como ponto de partida, resolvendo as lacunas existentes ou ii) o Banco estabelece sua própria regra e aplica a todos os clientes, solicitando a adaptação. $\mathrm{O}$ NBD adotou o primeiro processo, privilegiando a adoção dos sistemas nacionais. Na 
prática, o resultado final é semelhante, uma vez que o sistema nacional e as adaptações exigidas são observados em ambos os processos.

Pergunta 3) A Carteira de Projetos do Conselho Sul-Americano de Infraestrutura e Planejamento (COSIPLAN) inclui atualmente 581 projetos de integração da infraestrutura física na América do Sul, sendo suas principais fontes de financiamento provenientes da CAF, do BID e do FONPLATA. A atuação do BNDES também foi muito significativa em alguns projetos da IIRSA/COSIPLAN.

O senhor enxerga uma possível complementariedade do NDB em relação a esses outros bancos muito atuantes na América do Sul? O NDB poderia financiar diretamente projetos da carteira do COSIPLAN?

Resposta 3) Se você observar a nossa estratégia, a integração dos membros é uma das prioridades. Caso outros membros da América do Sul integrem o Banco, esses projetos do COSIPLAN podem vir a fazer parte da agenda de projetos, possibilitando inclusive cofinanciamento com a CAF e o FONPLATA. Por enquanto, projetos que envolvam somente a parte brasileira podem ser incluídos na agenda de projetos. No futuro, com a adesão de novos membros dos países sul-americanos, os projetos do COSIPLAN podem ser incorporados.

Pergunta 4) Nos termos do art. 4 do Acordo Constitutivo do NBD, o banco poderá estabelecer escritórios regionais necessários ao desempenho de suas funções. $\mathrm{O}$ primeiro escritório regional será em Johanesburgo. Há em marcha algum plano ou previsão de estabelecimento de outros escritórios regionais, como no Brasil, na Índia ou na Rússia?

Resposta 4) Sim. Nos termos da minuta acordada em Fortaleza, o primeiro escritório regional será estabelecido na África do Sul, o segundo no Brasil, o terceiro na Rússia e o quarto na Índia. Há previsão de que o primeiro escritório regional seja inaugurado ainda esse ano. No Brasil, já existe uma demanda dos empresários brasileiros e do próprio governo brasileiro.

Pergunta 5) A moeda operacional do NDB tem sido objeto de discussão. A China, em particular, está realizando um esforço multifacetado para ampliar o papel do Yuan/renminbi no comércio global. Nos termos do artigo 24 do Acordo Constitutivo, o banco, em suas operações, poderá fornecer financiamento em moeda local do país no qual a operação seja realizada, desde que políticas adequadas sejam postas em prática para evitar descasamento significativo de moedas. Alguns economistas argumentam que, de modo geral, ao conduzir as atividades em uma moeda diferente do dólar, provavelmente os custos de transação podem 
aumentar, resultando em taxas de juros maiores. No entanto, outros argumentam que as altas taxas de juros podem ser mitigadas, evitando os custos significativos associados às flutuações cambiais. Qual a tua opinião a respeito?

Reposta 5) O próprio uso do termo moeda "local" deve ser questionado. O Rublo, o Renminbi e o Real não podem ser considerados como uma moeda "local". Trata-se de países com grandes territórios e populações. Por que queremos operar em moedas que não o dólar? No mundo multipolar haverá também o multicurrency, razão pela qual teremos que nos adaptar a essa realidade multidiversa do ponto de vista monetário. Nos anos de 1980-90, ouvíamos que dentro da globalização teríamos uma moeda global. Ocorre que essa moeda global é, na realidade, uma moeda nacional. O Banco, levando em conta as mudanças atuais e as estratégias estabelecidas, se propõe a captar em moeda nacional para evitar descasamento, retirando os riscos cambiais do projeto do cliente.

Pergunta 6) Apesar das recentes reformas realizadas na estrutura do poder decisório do FMI e do Banco Mundial, alguns teóricos argumentam que as fórmulas utilizadas ainda estão longe de atenuar os desequilíbrios existentes. Sob esse prisma, os desequilíbrios do poder de voto constituem ainda o maior problema das instituições de Bretton Woods e as reformas não podem ser consideradas uma conquista substancial quanto ao reforço da voz e da participação dos países em desenvolvimento. Essa realidade contribui para o progressivo enfraquecimento das instituições de Bretton Woods. Outros argumentam, entretanto, que reformas específicas contribuirão para a redução da precariedade e da desigualdade na economia global, tendo o FMI, o Banco Mundial e a OMC um papel crucial a desempenhar. Levando em conta a sua longa experiencia no FMI, qual a tua posição a respeito?

Reposta 6) Nos últimos dez anos, o Banco Mundial e o FMI passaram por diversos processos de reformas. Os desequlíbrios no poder de voto consituem um dos maiores - senão o maior - problemas das instituições de Bretton Woods. Isso do ponto de vista dos países em desenvolvimento, uma vez que, para os países desenvolvidos, pode constituir uma das maiores vantagens. Como brasileiros devemos questionar se essa composição é boa ou ruim e se o Brasil tem algo a trazer. Eu, pessoalmente, acredito que sim. As recentes reformas introduzidas no FMI e no Banco Mundial foram importantes e beneficiaram, sobretudo, os países emergentes maiores, dentre eles os BRICS. Entretanto, essas reformas não resolveram os desequilíbrios. Os BRICS possuem uma grande participação na economia mundial, proporcional aos países do G-7, em matéria de Paridade de Poder de Compra, com uma tendência a ultrapassar o G-7 nos próximos anos. Fato é que nós não estaríamos aqui 
debatendo essa questão se as demandas por reformas tivessem sido amplamente acolhidas. O NBD surgiu justamente em razão da morosidade de respostas por reformas amplas que contemplassem os anseios dos países emergentes. Levando em conta a minha experiência, foram oito anos de FMI, a minha impressão é que as instituições de Bretton Woods estão tendo enormes dificuldades de entrar no século XXI. Embora se esforcem, já que pretendem sobreviver, enfrantam inúmeros desafios, sobretudo porque carregam a inércia de instituições obsoletas e visões conservadoras.

Pergunta 7) Qual a tua opinião acerca do "BRICS plus"? O grupo BRICS deve ser inclusivo no sentido de agregar outros países emergentes?

Resposta 7) Essa questão transcende o Banco. Como brasileiro, posso responder que há duas maneiras de entender o BRICS plus: uma é restrita e foi inaugurada pela África do Sul em 2013, quando país convidou certo número de países africanos a participarem da Cúpula de Durban. O Brasil copiou o modelo e chamou os membros da UNASUL para a Cúpula de Fortaleza, em 2014. A Índia, na Cúpula de Goa, convidou os países do BISMTEC; a segunda visão é ampla, com especulações de convites transrregionais e de caráter permanente. Concernente ao BRICS plus, vale questionar quais seriam os países e qual a periodicidade. Os BRICS hoje possuem um certo equilíbrio geográfico. $\mathrm{O}$ ingresso de futuros membros deve levar em conta o peso econômico e a autonomia dos países. 


\section{ACORDO CONSTITUTIVO SOBRE O NOVO BANCO DE DESENVOLVIMENTO}

Os Governos da República Federativa do Brasil, da Federação da Rússia, da República da Índia, da República Popular da China e da República da África do Sul (coletivamente denominados países do BRICS):

Considerando a importância de cooperação econômica mais próxima entre os países do BRICS,

Reconhecendo a importância de prover recursos para projetos de promoção de infraestrutura e desenvolvimento sustentável nos países do BRICS e em outras economias emergentes e países em desenvolvimento;

Convencidos da necessidade de criar uma nova instituição financeira internacional de forma a intermediar recursos para os objetivos descritos acima;

Desejosos em contribuir para um sistema financeiro internacional conducente ao desenvolvimento econômico e social que respeite o meio ambiente global.

Acordam o seguinte:

\section{Capítulo I}

Estabelecimento, Objetivos, Funções e Sede

\section{Artigo 1}

Estabelecimento

O Novo Banco de Desenvolvimento (doravante, "o Banco"), estabelecido pelo presente Acordo, deverá operar de acordo com as seguintes disposições.

\section{Artigo 2}

Objetivos

O objetivo do Banco será mobilizar recursos para projetos de infraestrutura e desenvolvimento sustentável nos BRICS e em outras economias emergentes e países em desenvolvimento, para complementar os esforços existentes de instituições financeiras multilaterais e regionais para o crescimento global e o desenvolvimento.

\section{Artigo 3}

\section{Funções}

Para cumprir seu objetivo, o Banco está autorizado a exercer as seguintes funções:

(i) Utilizar recursos a sua disposição para apoiar projetos de infraestrutura e desenvolvimento sustentável, públicos ou privados, nos BRICS ou em outras economias emergentes e países em desenvolvimento, por meio da provisão de empréstimos, garantias, participação acionária ou outros instrumentos financeiros; 
(ii) Cooperar, de forma considerada apropriada pelo Banco e, dentro de seu mandato, com organizações internacionais, bem como com entidades nacionais, sejam públicas ou privadas, e em particular com instituições financeiras e bancos nacionais de desenvolvimento;

(iii) Fornecer assistência técnica para a preparação e implementação de projetos de infraestrutura e desenvolvimento sustentável aprovados pelo Banco;

(iv) Apoiar projetos de infraestrutura e desenvolvimento sustentável envolvendo mais de um país;

(v) Estabelecer ou ser encarregado da administração de Fundos Especiais criados para servirem a seus propósitos.

\section{Artigo 4}

Sede

a) O Banco tem sua sede em Xangai

b) O Banco poderá estabelecer escritórios necessários ao desempenho de suas funções. O primeiro escritório regional será em Johanesburgo.

\section{Capítulo II}

Membros, Votos, Capital e Ações

\section{Artigo 5}

\section{Adesão}

a) Os membros fundadores do Banco são a República Federativa do Brasil, a Federação da Rússia, a República da Índia, a República Popular da China e a República da África do Sul.

b) A adesão será aberta a membros das Nações Unidas em tal momento e tais termos e condições que o Banco determinar por uma maioria especial do Conselho de Governadores.

c) A adesão ao Banco será aberta a membros tomadores e não tomadores de empréstimos.

d) O Banco poderá aceitar, conforme decisão do Conselho de Governadores, instituições financeiras internacionais como observadores durante reuniões do Conselho de Governadores. Países interessados em se tornarem membros também poderão ser convidados como observadores, para estas reuniões.

\section{Artigo 6}

Votação

a) O poder de voto de cada membro deverá ser igual ao número de suas ações subscritas no capital social do Banco. Na eventualidade de qualquer membro deixar de pagar qualquer 
parcela do montante devido em função de suas obrigações relativas à integralização das ações prevista no Artigo 7 deste Acordo, tal membro deverá ficar inabilitado, pelo tempo em que persistir a falta de cumprimento, para exercer o percentual de seu poder de voto que corresponde ao percentual que a parcela devida mas ainda não paga representa no total das ações integralizadas subscritas por este membro no capital social do banco.

b) Exceto quando especificamente indicado neste Acordo, todas as decisões do Banco serão tomadas por maioria simples dos votos depositados. Onde disposto neste Acordo, uma maioria qualificada será compreendida como votos afirmativos de dois terços do poder de voto total dos membros. Onde disposto neste Acordo, uma maioria especial será compreendida como votos afirmativos de quatro dos membros fundadores, concomitante com votos afirmativos de dois terços do poder de voto total dos membros.

c) Em votações no Conselho de Governadores, cada Governador estará apto a depositar os votos do país-membro que representa.

d) Em votações no Conselho de Diretores, cada Diretor estará apto a depositar o número de votos que se contaram em sua eleição, os quais não precisarão ser depositados de forma unitária.

\section{Artigo 7}

Capital autorizado e Capital subscrito

a) O capital autorizado inicial do Banco será de cem bilhões de dólares (US\$ 100.000.000.000,00). O dólar onde quer que seja referido neste Acordo será entendido como sendo a moeda oficial de pagamento dos Estados Unidos da América.

b) O capital autorizado inicial do Banco será dividido em 1.000.000,00 (um milhão) de ações, tendo um valor nominal de cem mil dólares (US\$ 100.000,00) cada, as quais estarão disponíveis para subscrição somente pelos membros de acordo com as disposições deste Acordo. O valor de 1 (uma) ação será igualmente o montante mínimo a ser subscrito para participação de um único país.

c) O capital subscrito inicial do Banco será de cinquenta bilhões de dólares (US\$ 50.000.000.000,00). O capital social subscrito será dividido em ações integralizadas e ações exigíveis. Ações com valor agregado nominal de 10 bilhões de dólares (US\$ 10.000.000.000,00) serão ações integralizadas e ações com valor nominal agregado de quarenta bilhões de dólares (USD 40.000.000.000,00) serão ações exigíveis.

d) Um aumento do capital social autorizado e subscrito do Banco, bem como a proporção entre ações integralizadas e ações exigíveis, poderão ser decididos pelo Conselho de Governadores, em tal momento e em tais termos e condições que considere convenientes, por uma maioria especial do Conselho de Governadores. Neste caso, cada membro terá oportunidade razoável de subscrever, sob as condições estabelecidas no Artigo 8 e sob tais outras condições que o Conselho de Governadores decidirá. Nenhum membro, contudo, será obrigado a subscrever qualquer parcela de tal aumento de capital.

e) O Conselho de Governadores revisará, em intervalos não superiores a cinco anos, o capital social do Banco. 


\section{Artigo 8}

Subscrição de ações

a) Cada membro deverá subscrever ações do capital social do Banco. O número de ações a serem inicialmente subscritas pelos membros fundadores será aquele indicado no Anexo 1 deste Acordo, que especifica a obrigação de cada membro tanto para capital integralizado quanto para capital exigível. O número de ações a serem inicialmente subscritas por outros membros será determinado pelo Conselho de Governadores por maioria especial por ocasião da aceitação de sua adesão.

b) Ações do capital social inicialmente subscritas pelos membros fundadores serão emitidas ao valor nominal. Outras ações serão emitidas ao valor nominal, salvo no caso de o Conselho de Governadores decidir, em circunstancias especiais, emiti-las em outros termos.

c) Nenhum aumento na subscrição de qualquer membro no capital social tornar-se-á efetivo, e nem qualquer direito de subscrição será dispensado, caso tenha o efeito de:

(i) Redução do poder de voto dos membros fundadores abaixo de 55 (cinquenta e cinco) por cento do poder de voto total;

(ii) Aumento do poder de voto dos membros não tomadores de empréstimos acima de 20 (vinte) por cento do poder de voto total;

(iii) Aumento do poder de voto de um membro não fundador acima de 7 (sete) por cento do poder de voto total.

d) A responsabilidade dos membros pelas ações será limitada à parcela não paga de seu valor de emissão.

e) Nenhum membro será responsabilizado, em razão de sua participação como membro, por obrigações do Banco.

f) As ações não poderão ser penhoradas ou hipotecadas de forma alguma. Elas serão transferíveis somente ao Banco.

\section{Artigo 9}

Pagamento das subscrições

a) $\mathrm{Na}$ entrada em vigor deste Acordo, o pagamento do montante inicialmente subscrito por cada membro fundador para o capital social integralizado do Banco será feito em dólares, em 7 (sete) parcelas conforme indicado no Anexo 2. A primeira parcela será paga por cada membro em até 6 meses após a entrada em vigor deste Acordo. A segunda parcela será devida 18 (dezoito) meses após a entrada em vigor deste Acordo. As 5 (cinco) parcelas restantes terão vencimento sucessivamente 1 (um) ano a partir da data de vencimento da parcela anterior. 
b) O Conselho de Governadores determinará as datas de pagamento das quantias subscritas pelos membros do Banco para o capital social integralizado, às quais as disposições do parágrafo (a) deste artigo não se aplicam.

c) O pagamento das quantias subscritas do capital social exigível do Banco estará sujeito à chamada somente como e quando for requerido pelo Banco para atender às suas obrigações decorrentes de empréstimo de fundos para inclusão como recursos de capital ordinário do Banco ou de garantias cobertas por esses recursos. No caso de tais chamadas de capital, o pagamento poderá ser feito por opção do membro em questão, em moedas conversíveis ou na moeda requerida para o cumprimento da obrigação do Banco que tenha motivado a chamada de capital.

d) As chamadas sobre as subscrições não integralizadas serão proporcionalmente uniformes para todas as ações exigíveis.

\section{Capítulo III}

Organização e Administração

\section{Artigo 10}

\section{Estrutura}

O Banco terá um Conselho de Governadores, um Conselho de Diretores, um Presidente e Vice-Presidentes conforme decidido pelo Conselho de Governadores, e quaisquer outros dirigentes e funcionários que sejam considerados necessários.

\section{Artigo 11}

Conselho de Governadores: composição e poderes

a) Todos os poderes do Banco estarão investidos no Conselho de Governadores, consistindo de um governador e um suplente indicados por cada membro da maneira que ele determinar. Os governadores serão de nível ministerial, e poderão ser substituídos ao agrado do membro que o nomeou. Nenhum suplente poderá votar exceto na ausência do seu titular. O Conselho de Governadores selecionará, anualmente, um dos governadores como seu presidente.

b) O Conselho de Governadores poderá delegar aos Diretores autorização para exercer quaisquer dos poderes do Conselho, com exceção dos seguintes:

(i) Admitir novos membros e determinar as condições de sua admissão;

(ii) Aumentar ou diminuir o capital social;

(iii) Suspender um membro;

(iv) Emendar este Acordo;

(v) Decidir sobre recursos contra interpretações dadas a este Acordo pelo Conselho de Diretores;

(vi) Autorizar a celebração de acordos gerais de cooperação com outras organizações internacionais; 
(vii) Determinar a distribuição dos lucros líquidos do Banco;

(viii) Decidir encerrar as operações do Banco e distribuir seus ativos;

(ix) Decidir sobre o número de Vice-Presidentes adicionais;

(x) Eleger o Presidente do Banco;

(xi) Aprovar proposta do Conselho de Diretores para chamada de capital;

(xii) Aprovar a Estratégia Geral do Banco a cada 5 (cinco) anos.

c) O Conselho de Governadores realizará uma reunião anual e tantas outras reuniões quantas sejam decididas pelo Conselho ou convocadas pelos Diretores. As reuniões do Conselho serão convocadas pelos Diretores sempre que solicitadas pelos membros, em número que será determinado pelo Conselho de Governadores, de tempos em tempos.

d) O quórum para qualquer reunião do Conselho de Governadores será uma maioria dos Governadores, exercendo não menos que dois terços do poder de voto total.

e) O Conselho de Governadores poderá estabelecer por meio de regulamentação um procedimento pelo qual os Diretores, quando considerarem que essa ação seja de interesse do Banco, possam obter um voto dos Governadores sobre uma questão específica sem a convocação de uma reunião do Conselho.

f) O Conselho de Governadores, e os Diretores dentro dos limites autorizados, poderão adotar normas e regulamentos que sejam necessários ou apropriados para a condução dos negócios do Banco.

g) Governadores e Suplentes exercerão suas funções sem remuneração do Banco.

h) O Conselho de Governadores determinará o salário e os termos do contrato de serviço do Presidente.

i) O Conselho de Governadores conservará sua plena autoridade sobre qualquer questão delegada ao Conselho de Diretores sob o parágrafo (a) do Artigo 12.

\section{Artigo 12}

\section{Conselho de Diretores}

a) O Conselho de Diretores será responsável pela condução das operações gerais do Banco e, para esta finalidade, poderá exercer todos os poderes delegados a eles pelo Conselho de Governadores, em particular:

(i) Em conformidade com orientações gerais do Conselho de Governadores, tomar decisões relativas a estratégias de negócios, estratégias de países, empréstimos, garantias, investimentos em ações, empréstimos tomados pelo Banco, estabelecimento de procedimentos operacionais básicos e encargos, fornecimento de assistência técnica e outras operações do Banco;

(ii) Apresentar as contas de cada exercício financeiro para aprovação do Conselho de Governadores em cada encontro anual; 
(iii) Aprovar o orçamento do Banco.

b) Cada membro fundador indicará 1 (um) Diretor e 1 (um) Suplente. O Conselho de Governadores estabelecerá, por maioria especial, a metodologia por meio da qual Diretores e Suplentes adicionais serão eleitos, de tal modo que o número total de Diretores não será superior a $10(\mathrm{dez})$.

c) Os Diretores exercerão um mandato de 2 (dois) anos e poderão ser reeleitos. Um Diretor continuará em seu cargo até que seu sucessor tenha sido escolhido e qualificado. Suplentes terão plenos poderes, para agir em nome de seu respectivo Diretor quando ele não estiver presente.

d) O Conselho de Diretores indicará um presidente não-executivo dentre os Diretores por mandato de 4 (quatro) anos. Se o Diretor não servir por um mandato completo ou se ele não for reeleito para um segundo mandato, o Diretor que o substituir servirá como Presidente pelo restante do mandato.

e) O Conselho de Diretores deverá aprovar a organização básica do Banco mediante proposta do Presidente, incluindo o número e as responsabilidades gerais dos principais cargos administrativos e profissionais do quadro de funcionários.

f) O Conselho de Diretores deverá indicar um Comitê de Crédito e Investimento e poderá indicar outros comitês que julgar conveniente. A participação em tais Comitês não precisa ser limitada a Governadores, Diretores ou Suplentes.

g) O Conselho de Diretores funcionará como órgão não residente, que se reunirá trimestralmente, a menos que o Conselho de Governadores decida diferentemente por uma maioria qualificada. Se o Conselho de Governadores decidir tornar o Conselho de Diretores um órgão residente, o Presidente do Banco tornar-se-á, a partir de então, o Presidente do Conselho de Diretores.

h) O quórum para qualquer reunião dos Diretores será uma maioria dos Diretores exercendo não menos que dois terços do total do poder de voto.

i) Qualquer membro do Banco poderá enviar um representante para participar de qualquer reunião do Conselho de Diretores quando uma questão que afeta especialmente esse membro está sob consideração. Esse direito de representação será regulamentado pelo Conselho de Governadores.

\section{Artigo 13}

Presidente e funcionários

a) O Conselho de Governadores elegerá um Presidente proveniente de um dos membros fundadores de forma rotacional, que não será nem um Governador, nem um Diretor, nem um Suplente de um ou outro. O Presidente será um membro do Conselho de Diretores, mas não terá voto, exceto um voto de desempate em caso de empate. O presidente poderá participar das reuniões do Conselho de Governadores, mas não votará em tais reuniões. Sem prejuízo para o mandato estabelecido pelo item (d) abaixo, o Presidente deixará de exercer o cargo, se o Conselho de Governadores assim decidir por uma maioria especial. 
b) O Presidente será o chefe do pessoal operacional do Banco e conduzirá, sob a orientação dos Diretores, os negócios ordinários do Banco, em particular:

(i) O Presidente será responsável pela organização, indicação e demissão de dirigentes e funcionários, e pela recomendação de admissão e demissão dos Vice-Presidentes ao Conselho de Governadores, responsabilidades sobre as quais deverá prestar contas ao Conselho de Diretores.

(ii) O Presidente presidirá o Comitê de Crédito e de Investimento, composto também pelos Vice-Presidentes, que será responsável por decisões sobre empréstimos, garantias, investimentos em ações e assistência técnica não superior a um valor limite a ser estabelecido pelo Conselho de Diretores, desde que nenhuma objeção seja apresentada por qualquer membro do Conselho de Diretores no prazo de 30 (trinta) dias contados da apresentação de tal projeto ao Conselho.

c) Haverá pelo menos 1 (um) Vice-Presidente proveniente de cada membro fundador, exceto do país representado pelo Presidente. Os Vice-Presidentes serão indicados pelo Conselho de Governadores com base em recomendação do Presidente. Os Vice-Presidentes exercerão autoridade e desempenharão funções na administração do Banco conforme determinado pelo Conselho de Diretores.

d) O Presidente e cada Vice-Presidente exercerão um mandato de 5 (cinco) anos, não renovável, exceto no caso do primeiro mandato dos primeiros Vice-Presidentes, cujo mandato será de 6 (seis) anos.

e) O Banco, seus dirigentes e empregados, não poderão interferir nos assuntos políticos de qualquer membro, nem ser influenciados nas suas decisões pelo caráter político do membro ou membros em consideração. Apenas considerações econômicas serão relevantes para as suas decisões, e estas considerações serão ponderadas imparcialmente a fim de atingir o objetivo e as funções indicados nos Artigos 2 e 3.

f) O Presidente, Vice-Presidentes, dirigentes e funcionários do Banco, no exercício de suas funções, estarão subordinados exclusivamente ao Banco e a nenhuma outra autoridade. Cada membro do Banco deverá respeitar o caráter internacional desta obrigação e se absterá de todas tentativas de influenciar qualquer um deles no exercício de suas funções.

\section{Artigo 14}

Publicação de Relatórios e Fornecimento de Informações

a) O Banco publicará um relatório anual contendo um balanço auditado de suas contas. Ele também transmitirá trimestralmente aos membros um balanço resumido da situação financeira e a demonstração de resultados, mostrando os resultados de suas operações ordinárias.

b) O Banco também poderá publicar outros relatórios que julgar convenientes para o cumprimento de seus objetivos e funções.

\section{Artigo 15}


Transparência e Prestação de contas

O Banco assegurará que seus processos sejam transparentes e elaborará, no respectivo Regulamento Interno, disposições específicas referentes ao acesso de seus documentos.

\section{Capítulo IV}

Operações

\section{Artigo 16}

\section{Utilização de recursos}

Os recursos e instalações do Banco serão utilizados exclusivamente para implementar o objetivo e as funções estabelecidos respectivamente nos Artigos 2 e 3 deste Acordo.

\section{Artigo 17}

\section{Depositários}

Cada membro designará seu Banco Central como um depositário, no qual o Banco poderá manter suas disponibilidades na moeda de tal membro e outros ativos do Banco. Se um membro não possuir Banco Central, deverá designar, em acordo com o Banco, outra instituição para esse propósito.

\section{Artigo 18}

Categorias de operações

a) As operações do Banco consistirão em operações ordinárias e operações especiais. Operações ordinárias serão aquelas financiadas com os recursos do capital ordinário do Banco. Operações especiais serão aquelas financiadas pelos recursos de Fundos Especiais.

b) O capital ordinário do Banco incluirá o seguinte:

(i) Capital social subscrito do Banco, incluindo tanto ações integralizadas quanto ações exigíveis, exceto a parte que venha a ser separada para um ou mais Fundos Especiais;

(ii) Recursos captados por empréstimos tomados pelo Banco por força dos poderes conferidos no Capítulo 5 do deste Acordo, aos quais o compromisso de chamadas de capital previsto no item (c) do artigo $9^{\circ}$ é aplicável;

(iii) Recursos recebidos em reembolso de empréstimos ou garantias e procedimentos de liquidação de investimentos em ações realizados com os recursos indicados nos itens (i) e (ii) deste parágrafo;

(iv) Receita derivada de empréstimos e de investimentos em ações a partir dos recursos supramencionados ou de garantias às quais o compromisso de chamadas de capital indicado no item (c) do Artigo 9 do presente Acordo é aplicável; e

(v) Quaisquer outros recursos ou receitas recebidas pelo Banco, os quais não façam parte de recursos de seus Fundos Especiais.

c) Os recursos do capital ordinário e os recursos dos Fundos Especiais do Banco serão, em todos os momentos e em todos os aspectos, mantidos, utilizados, comprometidos, investidos, 
ou de qualquer outro modo dispostos de forma inteiramente independente entre eles. As demonstrações financeiras do Banco apresentarão as operações ordinárias e as operações especiais separadamente.

d) Os recursos do capital ordinário do Banco não serão, em nenhuma circunstância, gravados por, ou empregados para cobrir perdas ou passivos decorrentes de operações especiais ou outras atividades para as quais recursos de Fundos Especiais foram originalmente utilizados ou comprometidos.

e) Despesas diretamente pertencentes às operações ordinárias deverão ser cobertas pelos recursos do capital ordinário do Banco. Despesas diretamente pertencentes às operações especiais serão cobertas pelos recursos de Fundos Especiais.

\section{Artigo 19}

Métodos de Operação

a) O Banco poderá garantir, participar em e realizar empréstimos ou apoiar por meio de quaisquer outros instrumentos financeiros, projetos públicos ou privados, incluindo parcerias público-privadas, em qualquer país membro, bem como investir em ações, subscrever a emissão de valores mobiliários ou facilitar o acesso aos mercados de capitais internacionais de qualquer negócio ou empreendimento industrial, agrícola ou de serviços com projetos nos territórios dos países membros tomadores de empréstimos.

b) O Banco poderá cofinanciar, garantir ou cogarantir, em conjunto com instituições financeiras internacionais, bancos comerciais ou outras entidades adequadas, projetos dentro de seu mandato.

c) O Banco poderá fornecer assistência técnica para a preparação e implementação de projetos apoiados pelo Banco.

d) O Conselho de Governadores, por maioria especial, poderá aprovar uma política geral sob a qual o Banco seja autorizado a desenvolver as operações descritas nos itens anteriores deste artigo em relação a projetos públicos ou privados em uma economia emergente ou país em desenvolvimento não membro, sujeito à condição de que envolva um interesse material de um membro, tal como definido por essa política.

e) O Conselho de Diretores, por maioria especial, poderá excepcionalmente aprovar um projeto público ou privado específico em uma economia emergente ou país em desenvolvimento não membro envolvendo as operações descritas nos itens anteriores deste artigo. Operações com garantia soberana em não membros serão precificadas com plena consideração dos riscos soberanos envolvidos, dados os mitigadores de risco oferecidos, e quaisquer outras condições estabelecidas conforme o Conselho de Diretores venha a decidir.

\section{Artigo 20}

Limitações nas Operações 
a) O saldo total das operações ordinárias do Banco não excederá, em momento algum, o montante total de seu capital subscrito livre de obrigações, reservas e lucros retidos incluídos em seus recursos de capital ordinário.

b) O saldo total das operações especiais do Banco relativas a qualquer Fundo Especial não excederá, em momento algum, o montante total prescrito nos regulamentos desse Fundo Especial.

c) O Banco buscará manter diversificação razoável em seus investimentos em capital acionário. Não deverá assumir responsabilidade por administrar qualquer entidade ou empreendimento na qual tenha investimento, exceto quando necessário para salvaguardar seus investimentos.

\section{Artigo 21}

Princípios operacionais

As operações do Banco serão conduzidas de acordo com os seguintes princípios:

(i) O Banco aplicará sólidos princípios bancários, assegurará remuneração adequada e terá em devida conta os riscos envolvidos;

(ii) O Banco não financiará qualquer empreendimento no território de um membro se esse membro objetar a tal financiamento;

(iii) Na preparação de qualquer programa ou estratégia de país, no financiamento de qualquer projeto ou ao fazer descrição ou referência a um determinado território ou área geográfica em seus documentos, o Banco não terá pretendido fazer qualquer julgamento sobre a situação jurídica ou outra condição de qualquer território ou área;

(iv) O Banco não permitirá que um montante desproporcional de seus recursos seja usado para o benefício de qualquer membro. O Banco procurará manter uma diversificação razoável de todos os seus investimentos;

(v) O Banco não imporá restrições sobre a aquisição de bens e serviços de qualquer país membro com os recursos de qualquer empréstimo, investimento ou outro financiamento realizado nas operações ordinárias ou especiais do Banco, e condicionará, em todos os casos adequados, seus empréstimos e outras operações a convites a todos os membros para a apresentação de propostas;

(vi) Os recursos de qualquer empréstimo, investimento ou outro financiamento realizado nas operações regulares do Banco ou com Fundos Especiais estabelecidos pelo Banco serão utilizados apenas para aquisições em países membros de bens e serviços produzidos em países membros, exceto em qualquer caso em que o Conselho de Diretores determine permitir aquisições em um país não membro de bens e serviços produzidos em países não membros, em circunstâncias especiais que tornem tal aquisição apropriada;

(vii) O Banco tomará as medidas necessárias para assegurar que os recursos de qualquer empréstimo feito, garantido ou com participação do Banco, ou qualquer investimento em ações, sejam utilizados apenas para as finalidades para as quais o empréstimo ou o 
investimento em ações foi concedido e com a devida atenção para considerações de economia e eficiência.

\section{Artigo 22}

Termos e condições

a) No caso de empréstimos feitos, com participação ou garantidos pelo Banco e investimentos em ações, o contrato deverá estabelecer os termos e condições para o empréstimo, garantia ou investimento em ações em questão de acordo com as políticas estabelecidas pelo Conselho de Diretores, incluindo, se for o caso, aqueles relacionados ao pagamento do principal, juros e outras taxas, encargos, comissões, prazos, moedas e datas de pagamento em relação ao empréstimo, garantia ou investimento em ações, de acordo com as políticas do Banco. Ao estabelecer tais políticas, o Conselho de Diretores terá plenamente em conta a necessidade de salvaguardar a sua renda.

b) Ao subscrever a venda de valores mobiliários o Banco deverá cobrar taxa, nos termos e condições estabelecidos nas políticas do Banco.

\section{Artigo 23}

Fundos Especiais

a) $\mathrm{O}$ estabelecimento e administração de Fundos Especiais pelo Banco deverão ser aprovados pelo Conselho de Governadores por maioria qualificada e seguirão os objetivos estabelecidos no Artigo 2 deste Acordo.

b) Exceto quando o Conselho de Governadores especifique diferentemente, os Fundos Especiais prestarão contas e suas operações estarão sujeitas ao Conselho de Diretores.

c) O Banco poderá adotar regras e regulamentos especiais que venham a ser necessários para o estabelecimento, administração e utilização de cada Fundo Especial.

\section{Artigo 24}

Disponibilidade de moedas

O Banco, em suas operações, poderá fornecer financiamento em moeda local do país no qual a operação seja realizada, desde que políticas adequadas sejam postas em prática para evitar descasamento significativo de moedas.

\section{Artigo 25}

Métodos de custear as perdas do Banco

a) Em casos de inadimplência em empréstimos feitos, com participação ou garantidos pelo Banco em suas operações ordinárias, o Banco tomará, primeiramente, todas as ações necessárias que considere apropriadas a fim de recuperar os empréstimos feitos e, em 
segundo lugar, ele poderá modificar os termos dos empréstimos, exceto a moeda de pagamento.

b) Perdas resultantes das operações ordinárias do Banco serão cobertas:

(i) Primeiro, pelas provisões do Banco;

(ii) Segundo, da renda líquida;

(iii) Terceiro, das reservas especiais;

(iv) Quarto, da reserva geral e excedentes;

(v) Quinto, do capital integralizado livre de obrigações; e

(vi) Por fim, do montante apropriado de capital subscrito exigível não integralizado, o qual será chamado de acordo com as provisões dos parágrafos (c) e (d) do Artigo 9 deste Acordo Constitutivo.

c) Ao envidar esforços para a recuperação de crédito em caso de inadimplência, o Banco procurará a assistência das autoridades do país onde a operação se realiza.

\section{Capítulo V}

Captação de Empréstimos e outros Poderes Adicionais

\section{Artigo 26}

Poderes Gerais

Além dos poderes especificados em outras partes do presente Acordo, o Banco terá o poder de:

(a) Tomar empréstimos em países membros ou em outros locais e, nesse contexto fornecer o colateral ou outras garantias para esse fim conforme o Banco determinará, sempre desde que:

(i) Antes de realizar a emissão de suas obrigações no território de um país membro, o Banco deverá ter obtido sua aprovação;

(ii) Quando as obrigações do Banco forem denominadas em moeda de um membro, o Banco deverá ter obtido sua aprovação;

(iii) O Banco obterá a aprovação dos países mencionados nos itens (i) e (ii) deste parágrafo para que os recursos obtidos possam ser trocados sem restrição por outras moedas; e

(iv) Antes de determinar a emissão de suas obrigações em um determinado país, o Banco deverá levar em consideração o montante de empréstimos tomados anteriormente, se houver, nesse país, o montante de empréstimos tomados anteriormente em outros países, e a possível disponibilidade de fundos nesses outros países; e dará a devida consideração ao princípio geral de que os empréstimos contraídos devam, na medida do possível, ser diversificados quanto ao país de empréstimo. 
(b) Comprar e vender valores mobiliários que o Banco tenha emitido ou garantido, ou nos quais tenha investido, sempre desde que ele tenha obtido a aprovação de todo o país em cujo território os valores mobiliários sejam comprados ou vendidos;

(c) Garantir valores mobiliários nos quais tenha investido a fim de facilitar sua venda;

(d) Subscrever, ou participar na subscrição de, valores mobiliários emitidos por qualquer entidade ou empreendimento para objetivos compatíveis com o objetivo do Banco;

(e) Investir recursos, não necessários para suas operações, em obrigações que venha a determinar, e investir recursos administrados pelo Banco para pensões ou propósitos similares, em valores mobiliários negociáveis. Ao fazê-lo, o Banco dará a devida consideração a investir tais recursos nos territórios dos membros, em obrigações dos membros ou de seus nacionais;

(f) Exercer quaisquer outros poderes e estabelecer regras e regulamentos que possam ser necessários ou apropriados para a promoção de seus objetivos e funções, consistentes com as disposições deste Acordo.

\section{Artigo 27}

Advertência a ser colocada em valores mobiliários

Todo valor mobiliário emitido ou garantido pelo Banco deve conter em sua face uma declaração clara no sentido de que ele não constitui uma obrigação de qualquer governo, a menos que seja de fato uma obrigação de um governo em particular, em cujo caso ele assim indicará.

\section{Capítulo VI}

Situação Jurídica, Imunidades e Privilégios

\section{Artigo 28}

Objetivo do Capítulo

Para possibilitar que o Banco efetivamente cumpra com seu objetivo e execute as funções que lhe são confiadas, a situação jurídica, imunidades, isenções e privilégios estabelecidos neste Capítulo serão concedidos ao Banco, no território de cada membro.

\section{Artigo 29}

Situação jurídica

a) O Banco terá personalidade internacional plena.

b) No território de cada membro, o Banco terá personalidade jurídica plena, em particular, capacidade plena para:

(i) Celebrar contratos;

(ii) Adquirir e alienar bens móveis e imóveis; e

(iii) Instaurar procedimentos legais. 


\section{Artigo 30}

Posição do Banco quanto a processos judiciais

a) O Banco gozará de imunidade de qualquer forma de processo legal, exceto em casos decorrentes de ou em conexão com o exercício de seus poderes para tomar empréstimos, para garantir obrigações, ou para comprar e vender ou subscrever a venda de valores mobiliários, em cujos casos ações podem ser movidas contra o Banco, em cortes de jurisdição competente no território de um país no qual o Banco tenha sua sede ou escritórios, ou tenha indicado um agente com o propósito de aceitar serviço ou notificação de processo, ou tenha emitido ou garantido valores mobiliários.

b) Não obstante as disposições do parágrafo (a) deste Artigo, nenhuma ação será movida contra o Banco por qualquer membro, ou por qualquer agência ou órgão governamental, ou por qualquer entidade ou pessoa agindo diretamente ou indiretamente a favor ou invocando direitos de um membro, ou de qualquer agência ou órgão governamental de um membro. Os membros recorrerão a procedimentos especiais para a solução de controvérsias entre o Banco e seus membros como esteja prescrito neste Acordo, no estatuto e regulamentos do Banco, ou em contratos celebrados com o Banco.

c) Propriedade e ativos do Banco estarão imunes, onde quer que se encontrem e seja quem for seu detentor, de todas as formas de apreensão, penhora ou execução antes de proferida sentença judicial definitiva contra o Banco.

\section{Artigo 31}

Liberdade e Imunidade de Ativos e Arquivos

a) Propriedade e ativos do Banco, onde quer que se encontrem e seja quem for seu detentor, serão imunes a busca, requisição, confisco, expropriação ou qualquer outra forma de apreensão ou fechamento por ação legislativa ou executiva.

b) Os arquivos do Banco e, em geral, todos os documentos pertencentes a ele ou em poder do Banco, serão invioláveis, onde quer que estejam.

c) Na medida do necessário para que se cumpra com o objetivo e funções do Banco e em conformidade com as disposições deste Acordo, toda propriedade e outros ativos do Banco serão isentos de qualquer tipo de restrições, regulações, controles e moratória de qualquer natureza.

\section{Artigo 32}

Privilégios de Comunicações

Cada país membro concederá às comunicações oficiais do Banco o mesmo tratamento que concede às comunicações oficiais dos demais membros.

\section{Artigo 33}


Imunidades e Privilégios Pessoais

Todos os Governadores, Diretores, suplentes, dirigentes e empregados do Banco gozarão dos seguintes privilégios e imunidades:

(i) Imunidade de jurisdição em relação a atos por eles praticados no âmbito de suas atribuições oficiais, exceto quando o Banco renunciar a tal imunidade;

(ii) Quando não forem nacionais locais, as mesmas imunidades em relação a restrições de imigração, exigências de registro de estrangeiros e obrigações de serviço nacional e as mesmas facilidades quanto às disposições cambiais que são concedidas pelos membros aos representantes, dirigentes e empregados de nível comparável de outros membros;

(iii) Os mesmos privilégios em relação às facilidades de viagem que são concedidas pelos membros aos representantes, dirigentes e empregados de nível comparável de outros membros.

\section{Artigo 34}

Isenção de Tributação

a) O Banco, sua propriedade, outros ativos, rendas, transferências e as operações e transações que realiza em conformidade com este Acordo serão isentos de todos os impostos, de todas as restrições e de todos os direitos aduaneiros. O Banco será também isento de qualquer obrigação relativa ao pagamento, retenção ou arrecadação de qualquer imposto ou taxa.

b) Nenhum imposto será cobrado sobre ou em relação a salários e emolumentos pagos pelo Banco a Diretores, Suplentes, dirigentes ou empregados do Banco, incluindo os peritos em missão pelo Banco, exceto quando um membro, não obstante o Artigo 48, depositar com seu instrumento de ratificação, aceitação ou adesão uma declaração que tal membro reserva para si e suas subdivisões políticas o direito de taxar salários e emolumentos pagos pelo Banco aos cidadãos ou nacionais desse membro.

c) Nenhum imposto de qualquer espécie será cobrado sobre as obrigações ou valores mobiliários emitidos pelo Banco, incluindo qualquer dividendo ou juros deles decorrentes, seja quem for seu detentor:

(i) O qual discrimine tal obrigação ou valor mobiliário unicamente por ter sido emitido pelo Banco; ou

(ii) Se a única base jurisdicional para tal tributação for a localização ou a moeda em que é emitido, em que for pagável ou pago, ou a localização de qualquer escritório ou local de trabalho mantido pelo Banco.

d) Nenhum imposto de qualquer espécie será cobrado sobre qualquer obrigação ou valor mobiliário garantido pelo Banco, incluindo qualquer dividendo ou juros derivados, seja quem for seu detentor:

(i) O qual discrimine tal obrigação ou valor mobiliário unicamente por ter sido garantido pelo Banco; ou 
(ii) Se a única base jurídica para tal tributação for a localização de qualquer escritório ou local de trabalho mantido pelo Banco.

\section{Artigo 35}

Implementação

Cada membro, de acordo com seu sistema jurídico, tomará imediatamente as medidas necessárias para tornar efetivas no seu próprio território as disposições estabelecidas neste Capítulo e informará ao Banco das medidas que tomou sobre o assunto.

\section{Artigo 36}

Renúncia de imunidades, privilégios e isenções

As imunidades, privilégios e isenções conferidos sob este capítulo são concedidos no interesse do Banco. O Conselho de Diretores poderá renunciar, na medida e condições que venha a determinar, a qualquer das imunidades, privilégios e isenções conferidos por este Capítulo nos casos em que tal ação seria, em sua opinião, apropriada aos melhores interesses do Banco. O Presidente terá o direito e o dever de renunciar a qualquer imunidade, privilégio ou isenção em relação a qualquer dirigente, empregado ou perito do Banco, exceto do Presidente e de cada Vice-Presidente, quando, em sua opinião, a imunidade, privilégio ou isenção impediriam o curso da justiça e podem ser renunciados sem prejuízo aos interesses do Banco. Em circunstâncias semelhantes e nas mesmas condições, o Conselho de Diretores terá o direito e o dever de renunciar a qualquer imunidade, privilégio ou isenção em relação ao Presidente e a cada Vice-Presidente.

\section{Capítulo VII}

Retirada e Suspensão de Membros, Suspensão Temporária e Término das Operações do Banco

\section{Artigo 37}

\section{Retirada}

a) Qualquer membro pode retirar-se do Banco mediante a entrega ao Banco, em sua sede, de notificação por escrito de sua intenção de fazê-lo. Essa retirada se tornará definitivamente efetiva, e a filiação cessará, na data especificada na notificação, mas em nenhum caso antes de 6 (seis) meses após a notificação ser entregue ao Banco.

Contudo, em qualquer momento antes que a retirada se torne definitivamente efetiva, o membro poderá notificar o Banco por escrito do cancelamento de sua notificação de intenção de se retirar.

b) Após a retirada, o membro continuará responsável por todas as obrigações diretas e contingentes para com o Banco às quais estava sujeito na data da entrega da notificação de retirada, incluindo aquelas especificadas no Artigo 39. Entretanto, se a retirada se tornar definitivamente efetiva, o membro não incorrerá em qualquer responsabilidade pelas obrigações resultantes de operações do Banco efetuadas após a data em que a notificação de retirada foi recebida pelo Banco. 
c) Ao receber a notificação de retirada, o Conselho de Governadores adotará procedimentos para liquidação de contas com o país membro que se retira, no mais tardar na data em que a retirada se torne efetiva.

\section{Artigo 38}

Suspensão de um Membro

a) Se um membro deixar de cumprir qualquer de suas obrigações com o Banco, o Banco poderá suspender a sua filiação por decisão do Conselho de Governadores, por maioria especial.

b) O membro suspenso dessa forma cessará automaticamente de ser membro do Banco por 1 (um) ano a partir da data de sua suspensão, a menos que o Conselho de Governadores decida pela mesma maioria terminar a suspensão.

c) Enquanto estiver suspenso, o membro não poderá exercer quaisquer direitos sob este Acordo, exceto o direito de retirada, mas continuará sujeito a todas as suas obrigações.

d) O Conselho de Governadores adotará os regulamentos que venham a ser necessários para a implementação deste artigo.

\section{Artigo 39}

Liquidação de contas

a) Depois de um país deixar de ser um membro, ele não mais participará dos lucros ou prejuízos do Banco, nem incorrerá em qualquer responsabilidade em relação a empréstimos e garantias concedidas pelo Banco doravante. Entretanto, ele permanecerá responsável por todos os valores que deve ao Banco e pelos seus passivos contingentes para com Banco, enquanto qualquer parte dos empréstimos ou garantias contratadas pelo Banco, antes da data na qual o país deixou de ser um membro, permanecer pendente.

b) Quando um país deixa de ser um membro, o Banco providenciará a recompra do capital social desse país, como parte da liquidação de contas, nos termos das disposições deste Artigo; mas o país não terá outros direitos sob este Acordo, exceto o disposto neste Artigo e no Artigo 46.

c) O Banco e o país que deixa de ser um membro podem concordar com a recompra do capital social nos termos que forem considerados apropriados nas circunstâncias, sem ter em conta as disposições do parágrafo seguinte. Tal acordo pode estipular, entre outras coisas, a liquidação final de todas as obrigações do país para com o Banco.

d) Se o acordo referido no parágrafo anterior não for concluído no prazo de 6 (seis) meses depois que o país deixar de ser membro ou em outro prazo conforme o Banco e esse país acordarem, o preço de recompra do capital social desse país será seu valor contábil, de acordo com a contabilidade do Banco, na data em que o país cessou de ser um membro. Essa recompra estará sujeita às seguintes condições: 
(i) O pagamento poderá ser feito em tais parcelas, em tais prazos e em tais moedas disponíveis que o Banco determinar, tendo em conta a situação financeira do Banco;

(ii) Qualquer montante que o Banco deva ao país para a recompra de seu capital social será retido na medida em que o país ou qualquer de suas subdivisões ou agências mantenham passivos perante o Banco como resultado de operações de empréstimos ou de garantias. $\mathrm{O}$ montante retido pode, por opção do Banco, ser aplicado em qualquer destes passivos à medida que vencerem. Entretanto, nenhum montante será retido por conta de passivo contingente do país para chamadas futuras de sua subscrição, nos termos do Artigo 9(c);

(iii) Se o Banco sofrer perdas líquidas em quaisquer empréstimos ou participações, ou como resultado de quaisquer garantias por saldar na data em que o país deixou de ser membro, e o montante de tais perdas excederem o montante das reservas provisionadas para isto nessa data, tal país deverá pagar sob demanda o montante pelo qual o preço de recompra de suas ações teria sido reduzido, se as perdas tivessem sido levadas em conta quando o valor contábil das ações, de acordo com a contabilidade do Banco, foi determinado. Além disso, o ex-membro permanecerá responsável por qualquer chamada nos termos do Artigo 9 (c), na medida em que ele teria sido obrigado a responder se a insuficiência de capital tivesse ocorrido e a chamada tivesse sido feita no momento em que o preço de recompra de suas ações tinha sido determinado.

e) Em nenhuma circunstância qualquer quantia devida a um país por suas ações nos termos desta seção será paga até 12 (doze) meses após a data em que o país cessou de ser um membro. Se nesse período, o Banco terminar as operações, todos os direitos de tal país serão determinados pelas disposições dos Artigos 41 a 43, e tal país será considerado ainda um membro do Banco, para os objetivos de tais artigos, exceto que ele não terá direito a voto.

\section{Artigo 40}

Suspensão temporária de operações

Numa emergência, o Conselho de Diretores poderá suspender temporariamente operações relativas a novos empréstimos, garantias, subscrição, assistência técnica e investimentos em ações enquanto se aguarda uma oportunidade para consideração adicional e ação pelo Conselho de Governadores.

\section{Artigo 41}

Término de operações

O Banco poderá encerrar suas operações por decisão do Conselho de Governadores, por maioria especial. Em caso de término de operações, o Banco cessará imediatamente todas as atividades, exceto aquelas relativas à ordenada conversão, conservação e preservação de seus ativos e liquidação de suas obrigações.

\section{Artigo 42}

Responsabilidade dos Membros e Pagamento de Credores 
a) A responsabilidade de todos os membros decorrente das subscrições ao capital social do Banco e no que diz respeito à depreciação de suas moedas continuará até que todas as obrigações diretas e contingentes tenham sido quitadas.

b) Todos os credores diretos serão pagos com os ativos do Banco e, em seguida, a partir de pagamentos ao Banco das subscrições não pagas ou exigíveis. Antes de efetuar qualquer pagamento a credores diretos, o Conselho de Diretores tomará as medidas que sejam necessárias, em sua opinião, para assegurar uma distribuição proporcional entre os credores diretos e contingentes.

\section{Artigo 43}

Distribuição de ativos

a) Nenhuma distribuição de ativos será feita aos membros por conta de suas subscrições ao capital social do Banco até que todos os passivos para com credores exigíveis de tal capital social tenham sido quitados ou provisionados. Além disso, tal distribuição deve ser aprovada por uma decisão do Conselho de Governadores por maioria especial.

b) Qualquer distribuição dos ativos do Banco aos membros será proporcional ao capital social detido por cada membro e será efetuada em tais prazos e sob tais condições que o Banco considere justos e equitativos. As frações de ativos distribuídas não precisam ser uniformes quanto ao tipo de ativos. Nenhum membro terá direito de receber a sua parte em tal distribuição de ativos enquanto não houver liquidado todas as suas obrigações para com o Banco.

c) Qualquer membro que receber ativos distribuídos nos termos deste artigo gozará dos mesmos direitos no que diz respeito a tais ativos que o Banco gozava antes de sua distribuição.

\section{Capítulo VIII}

Emendas, Interpretação e Arbitragem

\section{Artigo 44}

Emendas

a) O presente Acordo só poderá ser emendado por decisão do Conselho de Governadores, por maioria especial.

b) Qualquer proposta para introduzir modificações neste Acordo, quer emanando de um membro, um Governador ou do Conselho de Diretores, será comunicada ao Presidente do Conselho de Governadores, o qual a submeterá à consideração do Conselho. Se a emenda proposta for aprovada pelo Conselho, o Banco indagará a todos os membros se aceitam a emenda proposta. Quando a emenda for aceita, ratificada ou aprovada por 2/3 (dois terços) dos membros, o Banco certificará o fato por meio de comunicação formal endereçada a todos os membros. 
c) As emendas entrarão em vigor para todos os membros 3 (três) meses após a data da comunicação formal prevista no parágrafo (b) deste Artigo, ao menos que o Conselho de Governadores especifique um período diferente.

\section{Artigo 45}

Interpretação

a) Qualquer questão de interpretação das disposições deste Acordo que surja entre um membro e o Banco ou entre quaisquer membros do Banco será submetida ao Conselho de Diretores para decisão.

b) Membros especialmente afetados pela questão em consideração terão o direito de se fazer representar diretamente perante o Conselho de Diretores, conforme previsto no Artigo 12 (i).

c) Em qualquer caso em que o Conselho de Diretores tenha tomado uma decisão sob o item (a) acima, qualquer membro poderá exigir que a questão seja submetida ao Conselho de Governadores, cuja decisão será final. Até a decisão do Conselho de Governadores, o Banco poderá, conforme considere necessário, atuar com base na decisão do Conselho de Diretores.

\section{Artigo 46}

Arbitragem

a) Se um desacordo surgir entre o Banco e um país que cessou de ser um membro, ou entre o Banco e qualquer membro após a adoção da decisão de terminar as operações do Banco, tal desacordo será submetido à arbitragem de um tribunal de 3 (três) árbitros. Um dos árbitros será designado pelo Banco, outro pelo país interessado e o terceiro, salvo acordo diferente entre as partes, por uma autoridade que venha a ser aprovada pelo Conselho de Governadores. Se todos os esforços para alcançar um acordo unânime fracassarem, as decisões serão tomadas por maioria de votos entre os 3 (três) árbitros.

b) Ao terceiro árbitro serão conferidos poderes para resolver todas as questões de procedimento em qualquer caso em que as partes estejam em desacordo sobre a matéria.

c) Qualquer desacordo relativo a um contrato entre o Banco e um país tomador de empréstimo será resolvido de acordo com o respectivo contrato.

\section{Artigo 47}

Aprovação tácita

Sempre que a aprovação de qualquer membro for necessária antes que qualquer ato possa ser tomado pelo Banco, a aprovação será considerada como tendo sido dada, a menos que o membro apresente uma objeção dentro de um prazo razoável, que o Banco poderá fixar ao notificar o membro a respeito do ato proposto. 


\section{Capítulo IX}

Disposições finais

Artigo 48

Aceitação

a) Cada país signatário deverá depositar junto ao Governo da República Federativa do Brasil um instrumento demonstrando que aceitou, ratificou ou aprovou o presente Acordo, em consonância com sua legislação interna.

b) O Governo da República Federativa do Brasil enviará cópias autenticadas deste Acordo para os signatários e lhes notificará devidamente de cada depósito do instrumento de aceitação, ratificação ou aprovação que se efetue em conformidade com o parágrafo anterior, bem como as respectivas datas.

c) Após a data na qual o Banco inicie suas operações, o Governo da República Federativa do Brasil poderá receber o instrumento de adesão a este Acordo de qualquer país cuja adesão tenha sido aprovada conforme o Artigo 5(b).

d) A aceitação, ratificação ou aprovação deste Acordo, ou a adesão a ele, não conterá qualquer objeção ou reserva.

\section{Artigo 49}

Entrada em vigor

a) Este Acordo entrará em vigor quando os instrumentos de aceitação, ratificação ou aprovação tiverem sido depositados, em conformidade com o artigo 48, por todos os países do BRICS.

b) Os países do BRICS cujos instrumentos de aceitação, ratificação ou aprovação forem depositados antes da data na qual o Acordo entre em vigor se tornarão membros na data em que ele entre em vigor. Outros países se tornarão membros na data em que seus instrumentos de adesão forem depositados.

\section{Artigo 50}

Início de operações

A presidência do BRICS convocará a primeira reunião do Conselho de Governadores logo que o presente Acordo entre em vigor, nos termos do Artigo 49 deste Capítulo, a fim de tomar as decisões necessárias para a operação inicial do Banco. 


\author{
ANEXO 3 \\ DECRETO N $^{\circ} 8.702$, DE $1^{\circ}$ DE ABRIL DE 2016 \\ Promulga o Tratado para o Estabelecimento do Arranjo \\ Contingente de Reservas dos BRICS, de 15 de julho de 2014.
}

A PRESIDENTA DA REPÚBLICA, no uso da atribuição que lhe confere o art. 84, caput, inciso IV, da Constituição,

Considerando que a República Federativa do Brasil firmou o Tratado para o Estabelecimento do Arranjo Contingente de Reservas dos BRICS, em Fortaleza, em 15 de julho de 2014;

Considerando que o Congresso Nacional aprovou o Tratado para o Estabelecimento do Arranjo Contingente de Reservas dos BRICS, por meio do Decreto Legislativo n ${ }^{\circ} 130$, de 3 de junho de 2015; e

Considerando que o Governo brasileiro ratificou o Tratado em 24 de junho de 2015, que entrou em vigor para a República Federativa do Brasil, no plano jurídico externo, em 30 de julho de 2015, nos termos de seu Artigo 23;

\title{
DECRETA:
}

Art. $1^{\circ}$ Fica promulgado o Tratado para o Estabelecimento do Arranjo Contingente de Reservas dos BRICS, firmado em Fortaleza, em 15 de julho de 2014, anexo a este Decreto.

Art. $2^{\circ}$ São sujeitos à aprovação do Congresso Nacional atos que possam resultar em revisão do Tratado e ajustes complementares que acarretem encargos ou compromissos gravosos ao patrimônio nacional, nos termos do inciso I do caput do art. 49 da Constituição.

Art. $3^{\circ}$ Este Decreto entra em vigor na data de sua publicação.

Brasília, $1^{\circ}$ de abril de $2016 ; 195^{\circ}$ da Independência e $128^{\circ}$ da República.

Tratado para o Estabelecimento do

Arranjo Contingente de Reservas dos BRICS

O Arranjo Contingente de Reservas (ACR) dos BRICS é firmado entre a República Federativa do Brasil ("Brasil"), a Federação da Rússia ("Rússia"), a República da Índia ("Índia"), a República Popular da China ("China”) e a República da África do Sul (“África do Sul") (doravante referidos, individualmente, como "Parte" e, coletivamente, como "Partes"). 
CONSIDERANDO que as Partes concordam em estabelecer um Arranjo Contingente de Reservas autogerido para prevenir pressões de curto prazo no balanço de pagamentos, fornecer apoio mútuo e reforçar a estabilidade financeira.

CONSIDERANDO que as Partes concordam que este Arranjo Contingente de Reservas deverá contribuir para reforçar a rede global de proteção financeira e para complementar os arranjos monetários e financeiros internacionais existentes.

ASSIM, este Tratado estabelece os termos e condições do Arranjo Contingente de Reservas tal como se segue:

Artigo 1 - Objetivo

O ACR consiste em uma plataforma de apoio, por intermédio de instrumentos preventivo e de liquidez, em resposta a pressões de curto prazo, reais ou potenciais, sobre o balanço de pagamentos.

Artigo 2 - Montante e Compromissos Individuais

a. O total de recursos comprometidos inicialmente ao ACR será de cem bilhões de dólares dos Estados Unidos da América (US\$ 100 bilhões), com os seguintes compromissos individuais:

i. China - US\$ 41 bilhões

ii. Brasil - US\$ 18 bilhões

iii. Rússia - US\$ 18 bilhões

iv. Índia - US\$ 18 bilhões

v. África do Sul - US\$ 5 bilhões

b. A qualquer tempo, as Partes terão o direito de solicitar acesso aos recursos comprometidos. Até o momento em que uma das Partes (a "Parte Requerente") faça tal solicitação, e que essa solicitação seja aceita pelas demais Partes (as "Partes Provedoras") e efetuada por meio de um swap cambial, cada Parte manterá plenos direitos de propriedade e de posse sobre os recursos comprometidos ao ACR. Embora os compromissos não devam implicar transferências imediatas de fundos, os recursos comprometidos devem estar disponíveis para qualquer solicitação elegível.

Artigo 3 - Governança e Processo Decisório

a. A estrutura de governança do ACR será constituída por um Conselho de Governadores do ACR (o "Conselho de Governadores") e por um Comitê Permanente.

b. O Conselho de Governadores será composto por um Governador e um Governador Suplente, nomeados por cada Parte. Os Governadores devem ser Ministros de Finanças, Presidentes de Banco Central ou deter cargo equivalente. O Conselho de Governadores tomará as decisões por consenso e será responsável pelas decisões estratégicas e de alto nível do ACR. Por meio deste dispositivo, o Conselho de Governadores fica autorizado a:

i. Revisar e modificar o montante de recursos comprometidos ao ACR, bem como aprovar alterações no montante dos compromissos individuais; 
ii. Aprovar a entrada de novos países como Partes do ACR;

iii. Revisar e modificar os instrumentos do ACR;

iv. Revisar e modificar as políticas relativas a prazos, número de renovações, taxas de juros, spreads, comissões e demais taxas;

v. Revisar e modificar as precondições para saques e renovações;

vi. Revisar e modificar as disposições relativas a inadimplências e sanções;

vii. Revisar e modificar as disposições relativas a limites de acesso e multiplicadores;

viii. Revisar e modificar o percentual de acesso desvinculado de acordos com o FMI;

ix. Deliberar sobre a criação de um secretariado permanente ou o estabelecimento de uma unidade de supervisão específica;

X. Aprovar suas próprias regras de procedimento;

xi. Revisar e modificar as regras relativas à nomeação e às funções do coordenador do Conselho de Governadores e do Comitê Permanente;

xii. Revisar e modificar o poder de voto e as regras relativas à tomada de decisão do Comitê Permanente;

xiii. Revisar e modificar a autoridade e as funções do Comitê Permanente;

xiv. Aprovar as regras de procedimento relativas ao funcionamento do Comitê Permanente;

xv. Decidir sobre quaisquer outras questões não especificamente atribuídas ao Comitê Permanente.

c. O Comitê Permanente será responsável pelas decisões operacionais e de nível executivo do ACR e será composto por um Diretor e um Diretor Suplente, nomeados por cada Parte; estes deverão ser nomeados dentre os funcionários dos bancos centrais, salvo decisão em contrário da respectiva Parte. Por meio deste dispositivo, o Comitê Permanente fica autorizado a:

i. Preparar e submeter suas próprias regras de procedimento ao Conselho dos Governadores;

ii. Aprovar solicitações de apoio por meio dos instrumentos preventivo e de liquidez;

iii. Aprovar solicitações de renovação de apoio por meio dos instrumentos preventivo e de liquidez;

iv. Aprovar procedimentos operacionais para os instrumentos preventivo e de liquidez;

v. Determinar, em circunstâncias excepcionais, a dispensa da obrigação de cumprir com as condições de aprovação e de salvaguardas, e de apresentar os documentos exigidos nos termos deste Tratado;

vi. Aprovar a solicitação de resgate antecipado de uma Parte;

vii. Decidir sobre a imposição de sanções em caso de descumprimento deste Tratado;

viii. Exercer outras funções que lhe sejam atribuídas pelo Conselho de Governadores. 
d. Por princípio, o Comitê Permanente buscará o consenso em todas as matérias. As decisões do Comitê Permanente referentes aos itens C.ii e C.iii serão tomadas por maioria simples dos votos ponderados das Partes Provedoras. As decisões referentes aos itens C.v, C.vi e C.vii serão tomadas por consenso das Partes Provedoras. Todas as demais decisões do Comitê Permanente serão tomadas por consenso.

e. Sempre que uma decisão for tomada com base no voto ponderado, o peso atribuído ao voto de cada uma das Partes será determinado da seguinte forma: (i) 5\% do total de votos serão distribuídos igualmente entre as Partes; e (ii) o restante será distribuído entre as Partes de acordo com o montante relativo dos compromissos individuais.

Artigo 4 - Instrumentos

O ACR conterá os seguintes instrumentos:

i. Um instrumento de liquidez para prestar apoio em resposta a pressões de curto prazo no balanço de pagamento.

ii.Um instrumento preventivo destinado a prestar apoio em casos de potenciais pressões de curto prazo no balanço de pagamentos.

Artigo 5 - Limites de Acesso e Multiplicadores

a. $\mathrm{O}$ acesso das Partes aos recursos estará sujeito a limites máximos, que serão iguais a um múltiplo do compromisso individual de cada Parte, conforme estabelecido abaixo:

i.China terá um multiplicador de 0,5

ii.Brasil terá um multiplicador de 1

ii.Rússia terá um multiplicador de 1

iii.Índia terá um multiplicador de 1

v.África do Sul terá um multiplicador de 2.

b.O montante total disponível no âmbito de ambos os instrumentos, preventivo e de liquidez, não deverá exceder o acesso máximo estipulado para cada Parte.

c.Uma parcela ("parcela desvinculada"), igual a 30\% do acesso máximo para cada uma das Partes, estará disponível, sujeita apenas à concordância das Partes Provedoras, que será concedida sempre que a Parte Requerente atender às condições previstas no Artigo 14 deste Tratado.

d.Uma parcela ("parcela vinculada ao FMI"), que consiste nos $70 \%$ restantes do acesso máximo, estará disponível para a Parte Requerente, sob as seguintes condições:

i. A concordância das Partes Provedoras, que será concedida sempre que a Parte Requerente atenda às condições previstas no Artigo 14; e

ii. Evidência da existência de um acordo em curso entre o FMI e a Parte Requerente que envolva o compromisso do FMI de prover financiamento à Parte Requerente com base em condicionalidades, e o cumprimento pela Parte Requerente dos termos e condições do referido acordo. 
e.Ambos os instrumentos definidos no Artigo 4 terão parcelas vinculadas ao FMI e desvinculadas.

f.Se uma Parte Requerente tiver um acordo em curso com o FMI, ela poderá acessar até $100 \%$ de seu limite de acesso máximo, observado o disposto no parágrafo (d) acima.

Artigo 6 - Acordo entre Bancos Centrais

A fim de executar as transações no âmbito dos instrumentos preventivo e de liquidez, mencionados no Artigo 1, o Banco Central do Brasil, o Banco Central da Federação da Rússia, o Banco da Reserva da Índia, o Banco Popular da China e o Banco da Reserva da África do Sul deverão celebrar um acordo entre eles, que estabelecerá as diretrizes e os procedimentos operacionais necessários.

Artigo 7 - Swaps Cambiais

Uma Parte poderá solicitar apoio por meio de um dos instrumentos previstos no Artigo 4, de acordo com os procedimentos estabelecidos pelo Comitê Permanente nos termos do artigo 13 deste Tratado. A provisão de dólares norte-americanos (US\$) para a Parte Requerente será efetuada por meio de swaps cambiais realizados entre os bancos centrais das Partes, com base em procedimentos operacionais comuns a serem definidos pelo Comitê Permanente, nos termos do artigo 3.C.iv, e do acordo entre bancos centrais, conforme o Artigo 6.

Artigo 8 - Definições

Os termos seguintes devem ter os respectivos significados previstos neste Artigo:

"Moeda da Parte Requerente" significa a moeda da Parte que solicita o saque de recursos por meio de swap cambial;

“Transação de Swap" significa uma transação entre o banco central da Parte Requerente e o banco central de uma Parte Provedora, mediante a qual o banco central da Parte Requerente compra dólares norte-americanos (US\$) do banco central da Parte Provedora em troca de Moeda da Parte Requerente e recompra em data posterior a Moeda da Parte Requerente em troca de dólares norte-americanos (US\$);

"Saque" significa a compra, na Data-Valor (definida abaixo), de dólares norte-americanos (US\$) pelo banco central da Parte Requerente;

"Saque Desvinculado" significa um Saque pelo banco central de uma Parte que não esteja envolvida em um acordo com o FMI;

"Saque Vinculado ao FMI" significa um Saque pelo banco central de uma Parte que esteja envolvida em um acordo com o FMI;

"Dia Útil" significa qualquer dia em que os mercados estejam abertos para negócios em todos os centros financeiros necessários para que ocorram as transações de swap;

"Data da Transação" de um Saque ou da renovação de um Saque significa a data em que a taxa de câmbio do mercado à vista para o Saque ou renovação do Saque é estabelecida; 
"Data-Valor" de um Saque ou renovação de um Saque significa a data em que os bancos centrais da Parte Requerente e das Partes Provedoras creditam as contas umas das outras. A Data-Valor será o segundo Dia Útil após a Data da Transação;

"Data de Vencimento" de um Saque ou renovação de um Saque significa a data em que o banco central da Parte Requerente recomprará a Moeda da Parte Requerente em troca de dólares norte-americanos (US\$). Caso a referida Data de Vencimento não seja um Dia Útil, a Data de Vencimento será o próximo Dia Útil.

Artigo 9 - Coordenação

a. A Parte que preside os BRICS atuará como coordenador do Conselho de Governadores e da Comissão Permanente.

b. O coordenador deverá: (i) convocar e presidir as reuniões do Conselho de Governadores e do Comitê Permanente; (ii) coordenar a votação, quando necessário; (iii) prestar serviços de secretariado durante seu mandato; e (iv) informar às Partes sobre a ativação ou renovação dos instrumentos preventivo e de liquidez.

c. Qualquer Parte que solicitar ou receber apoio por meio de um instrumento preventivo ou de liquidez - Artigo 4 - ou optar por não participar como Parte Provedora ou pedir resgate antecipado de créditos a vencer - Artigo 15(e) - não exercerá a função de coordenador. Neste caso, o próximo presidente dos BRICS deverá assumir o papel de coordenador.

Artigo 10 - Compra e Recompra em uma Transação de Swap

a. A taxa de câmbio aplicável a cada compra e recompra em uma Transação de Swap deverá basear-se na taxa de câmbio em vigor (doravante denominada de "Taxa de Câmbio Swap") entre a Moeda da Parte Requerente e dólares norte-americanos (US\$) no mercado à vista da Parte Requerente na Data da Transação.

b. O banco central da Parte Requerente deverá vender a Moeda da Parte Requerente aos bancos centrais das Partes Provedoras e comprar deles os dólares norte-americanos (US\$) por meio de uma transação à vista, com o compromisso simultâneo, por parte do banco central da Parte Requerente, de vender dólares norte-americanos (US\$) e recomprar a Moeda da Parte Requerente dos bancos centrais das Partes Provedoras na Data do Vencimento. A mesma taxa de câmbio (ou seja, a taxa da transação à vista) deverá ser aplicada para as pontas à vista e a prazo da Transação de Swap.

c. Na Data do Vencimento, o banco central da Parte Requerente transferirá os dólares norteamericanos (US\$), acrescido de juros, de volta aos bancos centrais das Partes Provedoras em troca da Moeda da Parte Requerente. Nenhum juro incidirá sobre a Moeda da Parte Requerente.

Artigo 11 - Determinação da Taxa de Juros

a. A taxa de juros a ser paga pela Parte Requerente sobre os dólares norte-americanos (US\$) comprados das Partes Provedoras deverá ser uma taxa de juros de referência aceita internacionalmente para o vencimento correspondente da transação de swap, acrescida de um spread. O spread deverá aumentar periodicamente por certa margem, até um limite predeterminado. 
b. No caso do instrumento preventivo, o montante comprometido, mas não sacado, estará sujeito a uma comissão de compromisso, a ser especificada no acordo entre os bancos centrais.

Artigo 12 - Vencimentos

a. Um Saque Desvinculado, no caso do instrumento de liquidez, deverá ter uma Data de Vencimento seis meses após a Data-Valor e poderá ser renovado, no todo ou em parte, no máximo três vezes.

b. Um Saque Vinculado ao FMI, no caso do instrumento de liquidez, deverá ter uma Data de Vencimento um ano após a Data-Valor e poderá ser renovado, no todo ou em parte, no máximo duas vezes.

c. Se a Parte Requerente não estiver envolvida em um acordo com o FMI, o acesso ao instrumento preventivo deverá ter um prazo de seis meses, podendo ser renovado, no todo ou em parte, no máximo três vezes.

d. Se a Parte Requerente estiver envolvida em um acordo com o FMI, o acesso ao instrumento preventivo deverá ter um prazo de um ano, podendo ser renovado, no todo ou em parte, no máximo duas vezes.

e. No caso de instrumento preventivo, o prazo de vencimento de um Saque Desvinculado será de seis meses e o de um Saque Vinculado ao FMI será de um ano. O instrumento preventivo, uma vez sacado, não poderá ser renovado.

f. A Parte Requerente poderá recomprar a Moeda da Parte Requerente em troca de dólares norte-americanos à Taxa de Câmbio do Swap antes da Data de Vencimento. Neste caso, a taxa de juros incidente deverá ser calculada com base no número efetivo de dias decorridos desde (e incluindo) a Data-Valor até (mas não incluindo) a data de recompra antecipada.

Artigo 13 - Procedimentos para Solicitar ou Renovar Apoio por meio dos Instrumentos Preventivo e de Liquidez

a. A Parte que desejar solicitar apoio por meio dos instrumentos preventivo ou de liquidez, ou renovar esse apoio, deverá notificar os membros do Comitê Permanente sobre o tipo de instrumento, o montante requerido e a data de início prevista.

b. A Parte Requerente deverá apresentar evidências de que está em conformidade com as salvaguardas previstas no Artigo 14 abaixo.

c. Após receber a notificação, o coordenador do ACR deverá convocar reunião do Comitê Permanente para discutir e votar a solicitação da Parte Requerente. O Comitê Permanente deverá tomar uma decisão sobre a solicitação em até sete dias após a sua apresentação.

d. Uma vez aprovada a solicitação de apoio por meio do instrumento de liquidez, o banco central da Parte Requerente e os bancos centrais das Partes Provedoras deverão iniciar prontamente as Transações de Swap, dentro do prazo a ser especificado no acordo entre os bancos centrais.

e.Uma vez realizada solicitação de Saque no âmbito de um instrumento preventivo aprovado, o banco central da Parte Requerente e os bancos centrais das Partes Provedoras deverão 
iniciar prontamente as Transações de Swap, dentro do prazo a ser especificado no acordo entre os bancos centrais.

f. Se a Parte Requerente desejar renovar o apoio por meio do instrumento de liquidez, deverá notificar os membros do Comitê Permanente com antecedência mínima de quatorze dias antes da Data de Vencimento.

g. Se a Parte Requerente desejar renovar o apoio por meio do instrumento preventivo, deverá notificar os membros do Comitê Permanente com antecedência mínima de sete dias antes da expiração do período de acesso a tal instrumento.

Artigo 14 - Condições de Aprovação, Salvaguardas e Documentos Necessários

a. Ao submeter uma solicitação de apoio por meio de um instrumento de liquidez ou preventivo, ou a renovação desse apoio, a Parte Requerente deverá assinar e entregar uma carta de reconhecimento, comprometendo-se a cumprir com todas as obrigações e salvaguardas no âmbito deste Tratado.

b. A Parte Requerente também deverá concordar com as seguintes condições e salvaguardas:

(i) Submeter todos os documentos e dados econômicos e financeiros exigidos, conforme especificado pelo Comitê Permanente, e prestar esclarecimentos aos comentários;

(ii) Garantir que suas obrigações nos termos deste Tratado constituam sempre obrigações diretas, não garantidas e não subordinadas, com classificação pelo menos equivalente aos direitos de pagamento pari passu em relação a todas as demais obrigações externas diretas, presentes ou futuras, não garantidas e não subordinadas da Parte Requerente denominadas em moeda estrangeira;

(iii) Não ter dívidas em atraso com as demais Partes ou com suas instituições financeiras públicas;

(iv) Não ter dívidas em atraso com instituições financeiras multilaterais e regionais, incluindo o Novo Banco de Desenvolvimento (NBD);

(v) Estar em conformidade com as obrigações de supervisão e prestação de informações ao FMI, conforme definido, respectivamente, nos Artigos IV, Seções 1 e 3, e VIII, Seção 5, do Convênio Constitutivo da referida instituição.

Artigo 15 - Partilha de Encargos, Opção de Não Participar e Resgate Antecipado

a. As Partes Provedoras deverão compartilhar o desembolso de saques na proporção de seus respectivos compromissos com o ACR, de acordo com os parágrafos (b) e (c) deste Artigo. Em nenhuma circunstância, qualquer Parte deverá ser requisitada a prover mais recursos do que o montante o qual se comprometeu a prover no artigo 2(a).

b. A aprovação de uma solicitação de apoio por meio dos instrumentos de liquidez ou preventivo no âmbito deste Tratado suspende, durante o tempo em que esse apoio estiver em vigência, o compromisso da Parte Requerente de participar como Parte Provedora em qualquer solicitação de apoio subsequente por meio dos instrumentos de liquidez ou preventivo. 
c. Quando uma solicitação de apoio por meio dos instrumentos de liquidez ou preventivo, ou de renovação desse apoio, for apresentada, uma Parte poderá exercer a opção de não participar como Parte Provedora, caso isso seja justificado por fatores relacionados ao seu balanço de pagamentos e nível de reservas ou por evento de força maior, como guerra ou desastre natural. A Parte que exercer a opção de não participar deverá fornecer as informações necessárias para justificar a sua decisão. Neste caso, as demais Partes Provedoras deverão prover os recursos na proporção de seus compromissos com o ACR, de modo a permitir a opção de não participar de uma das Partes, sujeita ao parágrafo (a) deste Artigo.

d. Caso justificado por fatores relacionados ao seu balanço de pagamentos e nível de reservas ou por um evento de força maior, como guerra ou desastre natural, uma Parte Provedora poderá solicitar o resgate antecipado de créditos a vencer. A Parte Provedora que solicitar o resgate antecipado deverá fornecer as informações necessárias para justificar seu pedido. Caso a solicitação seja aprovada, as demais Partes Provedoras deverão prover recursos na proporção de seus compromissos com o ACR, de modo a permitir o resgate antecipado a uma das Partes, sujeita ao parágrafo (a) deste Artigo.

e. A Parte que tenha exercido a opção de não participar, solicitado resgate antecipado de um swap cambial a vencer ou feito a opção de não participar de um instrumento preventivo em aberto, não poderá exercer a função de coordenador, tal como definido no Artigo 9, durante o período da transação em que a Parte tenha exercido a opção de não participar ou de resgate antecipado.

Artigo 16 - Descumprimento de Obrigações e Sanções

a. O descumprimento por uma Parte Requerente das obrigações de pagamento na Data de Vencimento de um Saque ou renovação de um Saque, a menos que seja corrigido em um prazo de sete dias, deve resultar nas seguintes medidas:

(i) Todas as obrigações de repagamento a vencer da Parte Requerente para com as Partes Provedoras no âmbito deste Tratado tornar-se-ão imediatamente vencidas e exigíveis;

(ii) A elegibilidade da Parte Requerente para a realização de novos Saques ou renovação de Saques no âmbito deste Tratado será suspensa;

(iii) Qualquer parcela não sacada de um instrumento preventivo da Parte Requerente será cancelada; e

(iv) Quaisquer pagamentos das obrigações vencidas da Parte Requerente em relação às Partes Provedoras deverão ser realizados na mesma data e devem ser proporcionais aos valores devidos a cada uma das Partes.

b. No caso de um evento de força maior, a aplicação das medidas acima poderá ser suspensa.

c. No caso de atraso persistente e/ou injustificado na liquidação de obrigações de pagamento em atraso, o direito da Parte Requerente de participar em quaisquer decisões no âmbito deste Tratado poderá ser suspenso. Após 30 dias de descumprimento das obrigações de pagamento, as Partes Provedoras deverão considerar se essa ação é apropriada.

d. Se, transcorrido um período razoável após a decisão tomada nos termos do parágrafo (c), a Parte Requerente persistir no descumprimento de liquidar suas obrigações de pagamento 
em atraso, o Conselho dos Governadores poderá solicitar à Parte Requerente que se retire deste Tratado.

e. A Parte Requerente que estiver em descumprimento com uma obrigação de pagamento deverá concordar em adotar medidas para preservar o valor presente líquido de suas obrigações, caso as Partes Provedoras decidam, coletivamente, exercer essa opção.

f. No caso de as Partes Provedoras decidirem por consenso no âmbito do Conselho de Governadores, a Parte Requerente em descumprimento com uma obrigação de pagamento deverá concordar com uma novação de suas obrigações no âmbito deste Tratado, incluindo a emissão de títulos de dívida negociáveis que não estejam sujeitos à jurisdição da Parte Requerente. A Parte Requerente não deverá recusar seu consentimento, sem motivo razoável, aos termos e condições desses títulos de dívida, conforme estabelecido pelas Partes Provedoras.

g. A Parte Requerente estaria sujeita a uma taxa de atraso, além da taxa de juros, aplicada à transação de swap em relação à qual o pagamento esteja atrasado. Essa taxa de atraso deverá aumentar periodicamente, por uma determinada margem, até um limite predeterminado.

h. Em caso de descumprimento pela Parte Requerente de qualquer obrigação prevista neste Tratado, que não o descumprimento das obrigações de pagamento, poderão ser aplicadas as seguintes sanções:

(i) Todas as obrigações de pagamento a vencer no âmbito deste Tratado tornar-se-ão imediatamente vencidas e exigíveis;

(ii) A elegibilidade a novos Saques ou à renovação de Saques no âmbito deste Tratado deverá ser suspensa;

(iii) Qualquer parcela não sacada de instrumento preventivo deverá ser cancelada;

(iv) $\mathrm{O}$ direito de participar em quaisquer decisões no âmbito deste Tratado poderá ser suspenso;

(v) Transcorrido um período razoável após a decisão do item (iv), o Conselho de Governadores poderá exigir à Parte que se retire deste Tratado.

i. As sanções aplicadas devem ser proporcionais à gravidade do descumprimento.

Artigo 17 - Linguagem e Comunicação

a. A língua oficial do ACR será o inglês. As versões em idioma inglês do presente Tratado e de qualquer documentação em seu âmbito serão as versões oficiais. Toda a comunicação escrita e oral entre as Partes deve ser em inglês, salvo acordo em contrário, por escrito, entre as Partes.

b.Qualquer notificação, solicitação, documento ou outra comunicação submetida no âmbito deste Tratado deverá ser por escrito, deverá referir-se a este Tratado e deverá ser considerada plenamente transmitida ou enviada quando entregue em consonância com os detalhes de contato que deverão ser fornecidos separadamente por cada Parte.

Artigo 18 - Representação e Garantias

Cada uma das Partes garante e representa por meio deste que: 
a.Tem poder e autoridade plenos para celebrar e cumprir suas obrigações nos termos deste Tratado, e deverá apresentar evidências de tal autoridade, caso solicitada por qualquer outra Parte;

b.Este Tratado e o cumprimento das suas obrigações não contrariam qualquer lei ou outra restrição limitante sobre ele ou quaisquer de suas propriedades, e não há nenhum impedimento legal ou regulatório que possa afetar sua legalidade, validade ou aplicabilidade ou as obrigações nele presentes, ou que possa ter um efeito material adverso sobre a sua capacidade de desempenhar essas obrigações;

c.Todas as transações no âmbito deste Tratado devem ser isentas de quaisquer impedimentos legais ou administrativos para sua conclusão;

d.Todos os pagamentos nos termos deste Tratado deverão ser feitos sem retenção ou dedução por, ou em razão de, quaisquer impostos, taxas, outras contribuições ou encargos governamentais de qualquer natureza, presentes ou futuros, impostos ou cobrados em nome do seu país ou de qualquer autoridade que tenha o poder de tributar. No caso em que a retenção ou dedução de tais impostos, taxas, outras contribuições ou encargos governamentais sejam exigidos por lei, a Parte deverá pagar tais montantes adicionais, se necessário, a fim de que os montantes líquidos recebidos pelas demais Partes após essa retenção ou dedução sejam iguais aos montantes que teriam sido recebidos no âmbito deste Tratado na ausência de tal retenção ou dedução; e

e. Não poderá ceder, transferir, delegar, cobrar ou negociar suas obrigações nos termos deste Tratado sem o consentimento prévio, por escrito, das demais Partes.

Artigo 19 - Situação Jurídica do ACR

$\mathrm{O}$ ACR não possui personalidade jurídica internacional independente e não pode celebrar acordos, processar ou ser processado.

Artigo 20 - Solução de Controvérsias

a.Quaisquer litígios relativos à interpretação deste Tratado serão resolvidos por meio de consultas no âmbito do Conselho de Governadores.

b.Se qualquer disputa, controvérsia ou contestação referente à execução, interpretação, construção, violação, término ou invalidade de qualquer disposição deste Tratado surgir e não for solucionada amigavelmente pelo Conselho de Governadores num prazo razoável, deve ser resolvida por arbitragem, de acordo com as Regras de Arbitragem da Comissão das Nações Unidas para o Direito do Comércio Internacional (excluindo o artigo 26 das mesmas), em vigor na data deste Tratado (as "Regras Arbitrais da UNCITRAL"). No caso de se recorrer à arbitragem, o idioma a ser utilizado no processo será o inglês e o número de árbitros será de três.

c. As Partes concordam que, em qualquer arbitragem e em qualquer processo legal utilizados para o reconhecimento de uma sentença arbitral proferida em conformidade com este Artigo, incluindo qualquer processo necessário para o propósito de converter uma sentença arbitral em uma decisão judicial, não recorrerão a qualquer defesa a que não poderiam recorrer senão pelo fato de serem entidades estatais soberanas.

Artigo 21 - Denúncia e Término do Tratado 
a. Uma Parte poderá denunciar este Tratado mediante notificação de tal intenção às demais Partes seis meses antes da data prevista da denúncia. No entanto, a denúncia do Tratado por qualquer Parte não é permitida por um período de cinco anos após sua entrada em vigor.

b. Durante esse período de seis meses, a Parte que tenha notificado de tal intenção deve oferecer às demais Partes a oportunidade de expressar seus pontos de vista a respeito de sua intenção, mas não tem o direito de solicitar, nem a obrigação de prover recursos.

c. No caso de qualquer obrigação decorrente deste Tratado, inclusive qualquer obrigação de pagamento em dinheiro, permanecer pendente no momento do término ou da saída deste Tratado, todos os termos e condições deste Tratado (exceto aqueles que autorizam as Partes a realizar qualquer Saque ou renovação de Saque) continuarão aplicáveis até que tal obrigação tenha sido cumprida.

Artigo 22 - Aceitação, Depositário e Emendas

a. Este Tratado estará sujeito à aceitação, ratificação ou aprovação, de acordo com os respectivos procedimentos internos das Partes.

b. Os instrumentos de aceitação, ratificação ou aprovação serão depositados junto à República Federativa do Brasil, que será o depositário deste Tratado.

c. O depositário deverá informar prontamente todas as partes sobre: (i) a data do depósito de cada instrumento de aceitação, ratificação ou aprovação (ii) a data da entrada em vigor deste Tratado e de quaisquer emendas e mudanças no mesmo, e (iii) a data de recebimento de uma notificação de denúncia.

d. Se a Parte que atua como depositário decidir denunciar este Tratado, aplicar-se-ão todos os termos e condições do artigo 21, exceto que: (i) o depositário deverá notificar a sua intenção às demais Partes; e (ii) a partir da data de recebimento da notificação de denúncia do depositário, o papel de depositário será assumido por uma das demais Partes, conforme acordado entre elas.

e. Este Tratado não poderá ser objeto de reservas unilaterais.

f. Qualquer proposta de emendar este Tratado deverá ser comunicada à Parte que estiver exercendo a função de coordenador do Conselho de Governadores, que deverá então trazer a proposta perante o Conselho de Governadores. Se a emenda proposta for aprovada, o coordenador deverá indagar todas as Partes se aceitam a emenda proposta. Se uma Parte, de acordo com seus procedimentos internos, aceitar a proposta de emenda, ela deverá então notificar o depositário. A emenda entrará em vigor na data de recepção da última notificação. Qualquer decisão do Conselho de Governadores referente à modificação do Artigo 2 deverá ser considerada uma emenda.

Artigo 23 - Entrada em vigor

Este Tratado entrará em vigor 30 (trinta) dias após o depósito do quinto instrumento de aceitação, de acordo com as exigências legais de cada Parte.

Feito em Fortaleza, em 15 de julho de 2014, em cinco originais em inglês, um para cada Parte. 
PELA REPÚBLICA FEDERATIVA DO BRASIL

PELA FEDERAÇÃO DA RÚSSIA

PELA REPÚBLICA DA ÍNDIA

PELA REPÚBLICA POPULAR DA CHINA

PELA REPÚBLICA DA ÁFRICA DO SUL 